\title{
INSURED'S DUTY OF DISCLOSURE IN CANADIAN AND ENGLISH LAW
}

\author{
ISLAM AHMED SIDDIQUI*
}

In law, insurance contracts are said to be subject to the doctrine of uberrima fides, i.e., they are contracts of utmost good faith obliging both the insurer and the insured to conform to a high standard of conduct, especially regarding disclosure of material facts affecting the appreciation of the risk to be covered.

In theory, this doctrine applies equally to the insurer and the insured, but in practice it has come to mean that the insured is under a heavy onus of dis. closure when he applies for insurance coverage of any type, either personally or through an insurance agent.

The modern doctrines of disclosure originated in the law of marine in. surance in 16th century England. At that time, it was not unfair to expect a very high standard of disclosure from the insured, because as the owner of the vessel or cargo to be insured, he was in a better position than the underwriter to know the nature and extent of the risk to be covered. The underwriter was at a comparative disadvantage with regard to the accurate assessment of the risk.

The situation is vastly different today, since the insurance industry is wealthy, large and supremely organized. Its expertise in matters of risk assessment and its corps of trained personnel give it an undoubted advantage over the lay consumer of insurance services. Most risks of an ordinary consumer type are highly standardized, such as automobile coverage, package homeowner's coverage, and life insurance coverage.

Despite these tremendous changes in the insurance marketplace, the insurer continues to enjoy a preferred legal position in the area of disclosure of material facts. As will be seen, the classical doctrine was enunciated by Lord Mansfield in the 18th century and has not changed substantially since then.

In the face of well entrenched common law doctrines, the insurance con. sumer must rely upon legislative intervention for the fulfillment of his reasonable expectations. However, legislative regulation of standards of disclosure is piecemeal and ineffective. Occasionally, members of the judiciary have lamented this situation. For example, Fletcher Moulton L.J., of the English Court of Appeal, in the celebrated case of Joel $v$. Law Union \& Crown Ins. Co., observed that insurers want to be doubly secure by requiring the assured to guarantee as a condition for the validity of the policy the strict accuracy as well as the bona fides of answers to questions in the proposal form, even when the matters dealt with are technical in nature. The judge ended his remarks thus: "I wish I could adequately warn the public against such practices on the part of insurance offices."

It is therefore proposed to study the extent of the duty of disclosure as laid down by Lord Mansfield; to trace briefly the various stages of its development; to analyze the present state of the doctrine in the law; and to point out its deficiencies. Finally, an attempt will be made to introduce a series of recommendations arising out of the study with a view to reforming the law.

\section{HISTORICAL DEVELOPMENT OF THE DOCTRINE OF UBERRIMA FIDES-UNITED KINGDOM}

The applicant or proposer for insurance coverage in England is under a common law duty to make, at his own initiative, full disclosure of all material facts during the preliminary negotiations for the insurance contract. ${ }^{1}$ This doctrine of uberrima fides is based on the assumption that facts material to insurance are not generally within the knowledge of the

"B.Comm. (Karachi), L.L.B. (Karachi), L.L.M. (Alta.). This is a portion of his Master's thesis.

1 Joel v. Law Union and Crown Insurance Co. [1908] 2 K.B. 863 at 897 (C.A.). 
insurer, but are exclusively known to the proposer. ${ }^{2}$ As will be discussed later, while this may have been true historically, it is no longer the case when insurers know more about the subject matter of insurance than does the insured.

The duty of disclosure is a positive duty to disclose material facts, and a mere omission constitutes breach of the duty ${ }^{3}$ It is therefore not only concealment but also omission which has the effect of avoiding a contract of insurance. Generally, in non-marine cases, certain stipulations are inserted in the contract which may have the effect of defining, regulating or even limiting the needed disclosure; e.g., the introduction of the "basis clause" has the effect of making the truth of the answers in the application a condition of the validity of the policy irrespective of the materiality or otherwise of the fact in question. ${ }^{4}$

Conversely, the inclusion of specific questions in the proposal forms, as a matter of interpretation of the contract, can be taken to mean that the duty of disclosure is limited to questions asked. Unless such an intention to limit the duty can be clearly shown from the terms of the contract, the insured is subject to the full common law duty of disclosure. 5

The doctrine of uberrima fides is a broad concept from which the duty of disclosure flows as a corollary. The doctrine, as it developed, required utmost good faith of the contracting parties in contracts of insurance. If this was not observed by either party, the other party could avoid the contract irrespective of the innocence of his contractual partner. This is borne out by the pronouncements of Lord Mansfield in Carter v. Boehm. ${ }^{6}$ He made the following observations regarding the knowledge of material facts possessed by the insured: ${ }^{7}$

The special facts, upon which the contingent chance is to be computed, lie most commonly in the knowledge of the insured only. The underwriter trusts to his statement, and proceeds upon confidence that he does not keep back any circumstance in his knowledge, to mislead the underwriter into a belief that the circumstance does not exist, and to induce him to estimate the risk, as if it did not exist.

Discussing the effect of concealment or non-disclosure of material facts, the learned Chief Justice remarked: 8

The keeping back of such circumstance is a fraud, and therefore the policy is void. Although suppression should happen through mistake, without any fraudulent intention; yet still the underwriter is deceived, and the policy is void; because the risk run is really different from the risk understood and intended to be run, at the time of the agreement.

It follows from the foregoing that at common law, under the doctrine of uberrima fides, a failure to disclose or a misstatement of fact constituted a legal fraud. ${ }^{9}$

\section{A. Background of the Doctrine of Uberrima Fides}

The duty of the insured to disclose material facts in non-marine insurance was, at the end of the eighteenth century, a narrow one requiring the applicant for coverage to disclose only those facts exclusively within

\footnotetext{
2 London General Omnibus Co. v. Holloway [1912] 2 K.B. 72 at 85 (C.A.).

3 Chalmer's Marine Insurance Act, 1950, at 29, 30 (5th ed.).

- Dawson Ltd. v. Bonnin [1922] 2 A.C. 413 (H.L.).

5 Ewer v. National Employer's Mutual Gen. Ins. Ass. Ld. [1937] 2 All E.R. 193.

- (1766) 3 Burr. 1905.

7 Id. at 1909.

Id.

- Taylor v. London Ass. Corp. [1935] S.C.R. 422 at 425.
} 
his knowledge. ${ }^{10}$. The duty of obtaining material information was placed upon the insurer. ${ }^{11}$ What the underwriter, by fair inquiry, could learn from ordinary sources of information was not required to be disclosed. ${ }^{12}$ It was only fraudulent concealment on the part of an insured that avoided a policy. 13

In marine insurance, however, the insured was required to communicate every material circumstance irrespective of the intention or lack of intention to deceive. ${ }^{14}$ The reason for the rule was that the subject of insurance, i.e., a ship or cargo, was not available for inspection by insurer's surveyors which necessitated complete reliance on the description presented by the insured. ${ }^{15}$

The doctrine of disclosure as propounded by Lord Mansfield in the celebrated case of Carter v. Boehm has been misconceived and misapplied by English judges. This resulted in a number of unnecessarily wide judicial dicta, ${ }^{16}$ which assumed undue importance because they were followed rather slavishly in later cases. ${ }^{17} \mathrm{As}$ a consequence, the duty of disclosure at common law has been greatly increased. The insured is now required to communicate, without being asked, every material circumstance ${ }^{18}$ known or which ought to be known by him whether he thought it to be material or not. ${ }^{19}$ Even with regard to marine insurance, the eighteenth century doctrine did not go so far. ${ }^{20}$ On the other hand, if the insurer has instituted inquiries, such as those soliciting information on the application for coverage, it may be said to be in a position to discover the facts, but is not obliged to do so.21

The law in Canada requires a written application form, ${ }^{22}$ but the questions on the form do not necessarily exhaust the applicant's duty to disclose facts material to the risk. Since the source of the duty of disclosure is the common law, the courts may legitimately hold that although a specific question on a particular issue has not been asked in the application for insurance, the insured must disclose material facts in the ordinary discharge of his duty. On the other hand, the questions in the application define the limits of what is material, e.g., if the proposer for a fire insurance contract is asked to list the number of fires which he has had during the preceding three years, the specification of the period may relieve the applicant from disclosing a fire which took place prior to

10 Supra, n. 6 at 1915.

11 Id.

12 Frier v. Woodhouse (1817) Holt N.P. at 573.

13 Mayne v. Walter (1782) 3 Doug. K.B. 79; see, the report in Park, The Law of Marine Insurance $195 \& 363$ (1800) and 99, Douglas 1-4 K.B., Term Reports 1 at 548.

14 Salzman, Misrepresentation and Concealment in Insurance (1970-71) 8 Am. Bus. LJ. 119.

is Vance on Insurance 368 (3rd. ed. 1951).

16 Lindenau v. Desborough (1828) 8 B. \& C. 586; Bates v. Hewitt (1867) L.R. 2 Q.B. 595; London Assurance v. Mansel (1879) 11 Ch. D. 363; Rozanes v. Bowen (1928) 32 L1. L. Rep. 98 (C.A.); Australia and New Zealand Bank v. Colonial and Eagle Wharves Ltd. (1960) 2 Lloyd's Rep. 241.

12 (A) Lindenau v. Desborough, supra, n. 16 considered. London Assurance Co. v. Mansel supra, n. 6. Joel v. Law Union and Crown Ins. supra n. 1, and referred to Yorke v. Yorkshire Ins. [1918] 1 K.B. 662; Herbert v. Mercantile Fire Ins. Co. (1878) 43 U.C.Q.B. 384 (C.A.).

(B) Bates v. Hewitt, supra, n. 16 referred to Glicksman v. Lancashire \& Gen. Ass. Co. [1927]A.C. 139.

(C) London Ass. Co. v. Mansel, supra, n. 16 considered Joel v. Law Union \& Crown Ins. supra, n. 1.

it Rozanes v. Bowen, supra, n. 16.

10 Ionides v. Pender (1874) L.R. 9 Q.B. 537; Australia and New Zealand Bank v. Colonial and Eagle Wharves Ltd., supra, n. 16.

20 Hasson, The Doctrine of Uberrima Fides in Insurance Law-A Critical Evaluation, (1969) 32 Mod. L. Rev. 615 at 616.

21 Bates v. Hewitt, supra, n. 16 at 611.

22 In automobile and life insurance, a written application form is invariably required in Canada. In fire in. surance, the law in Alberta requires a written application form. It appears that in other provinces this is op-
tional. 
that period. The courts may, in such instances, find waiver of the duty to disclose prior occurrences. Whether the courts will find a strict duty of disclosure or waiver of such duty depends, in the absence of legislation, upon the construction of the contract and the circumstances of each case.

Apart from the rather strict attitude developed by English judges toward the applicant for insurance, a desire on the part of insurers to make themselves doubly secure has put another obstacle in the path of the insured. The "basis of contract clause", which made its debut around 1834 , in the reported case of Duckett v. Williams, ${ }^{23}$ was invented by insurance underwriters and required the insured to warrant, on pain of nullity of the insurance contract, the strict accuracy and bona fides of answers given to questions in the proposal form. This prompted Fletcher Moulton L.J., to make the following comments in the leading case of Joel v. Law Union \& Crown Insurance: ${ }^{24}$

Insurers are thus in the highly favourable position that they are entitled not only to bona fides on the part of the applicant but also to full disclosures of all knowledge possessed by the applicant that is material to the risk. And in my opinion they would have been wise if they had contented themselves with this. Unfortunately, the desire to make themselves doubly secure has made them depart widely from this position by requiring the assured to agree that accuracy, as well as the bona fides of his answers to various questions put to him by them or on their behalf, shall be a condition of the validity of the policy.... I wish I could adequately warn the public against such practices on the part of insurance offices.

When applying for insurance coverage, the insured is normally required to answer a number of questions, listed in an application form, ${ }^{25}$ designed to elicit information necessary for the assessment of the risk. Typically, the insured has to verify the accuracy of the answers by signing a declaration at the end of the proposal form which appears in a number of variations. In substance, the insured makes the following averment: ${ }^{26}$

I declare that the particulars and statements made by me above are correct, and I agree that they shall be the basis of the contract between me and the company.

The insurer may thus avoid liability by showing the inaccuracy of any statement, whether or not it was material to the contract. The House of Lords, in Anderson v. Fitzgerald, ${ }^{27}$ an Irish case dealing with a "basis of contract clause", said that its inclusion in the proposal form excluded the consideration of materiality by the jury. In Canada, however, the inclusion of the "basis clause" does not have the effect of avoiding a policy unless the inaccuracy is material to the acceptance of the risk. ${ }^{28}$

The test or standard of materiality, as laid down by English judges, is that of a "reasonable insurer" and not that of a "reasonable insured". Lord Esher, in Rivaz v. Gerussi ${ }^{29}$ stated:

Every circumstance is material which would influence the judgement of a prudent insurer in fixing the premium or determining whether he will take the risk.

\footnotetext{
${ }^{23}$ (1834) 2 Cr. \& M. 348.

24 Supra, n. 1 at 885 .

25 "In life and motor-vehicle insurance, this practice may be regarded as invariable; in fire insurance we understand that it is unusual, in other classes the practice probably varies." Law Reform Committee, Fifth Report (Conditions and Exceptions in Insurance Policies) Cmnd. 62 (1957), para. 6 at 4.

${ }^{26}$ Borrie and Diamond, The Consumer, Society and the Law 231 (2d. ed. 1968); see article by Hasson, The "Basis of the Contract Clause" in Insurance Law, (1971) 34 Mod. L. Rev. 29.

${ }^{27}$ (1853) 4 H.L. Cas. 484.

28 Insurance Acts. R.S.A. 1970, c. 187, s. 194(7); R.S.B.C. 1960, c. 197, s. 14(1); R.S.M. 1970, c. 126, s. 117(4); R.S.O. 1970 , c. 224 , 8. $98(5)$.

29 (1880) 6 Q.B.D. 229.
} 
In consequence, the layman, when applying for insurance coverage, must govern his disclosure of facts according to what a "reasonable insurer" would consider to be material to the underwriting of the risk. A formidable task indeed! A more detailed discussion of this subject will be presented in due course.

The insured has been placed in even a more difficult position by the fact that questions requiring him to state opinions have been treated as statements of facts; 30 for example, a question is asked whether the life proposed to be insured has suffered from illness or disease. The insured may not realize his affliction, but the medical expert of the company may determine that illness existed at the time of effecting insurance, and liability under the policy may be repudiated. In Canada, both the applicant and the life to be insured, when applying for insurance coverage, are required to disclose facts within their knowledge. However, the policy cannot be avoided for innocent non-disclosure or misrepresen. tation of a latent disease. ${ }^{31}$

Without restricting the generality of facts which an insured is required to disclose, he must communicate to the insurer the history of his claims; ${ }^{32}$ previous rejections of coverage by other insurers; ${ }^{33}$ his criminal convictions; 34 and, in some cases, his nationality. ${ }^{35}$

It may fairly be said that, in England, the insurer requires the disclosure of not only those facts which affect the risk, but of all the facts which will enable him to decide whether or not he will accept the risk and, if so, at what rate of premium. ${ }^{36}$

In the eighteenth century, the insured enjoyed an equal bargaining position vis-a-vis the insurer inasmuch as it was usual for the proposer or applicant to complete an insurance slip, and for the underwriters to affix their signatures to the same in order to indicate the extent of the risk they were prepared to assume. ${ }^{37}$ Following from this, two legal ideologies dear to the common law have greatly contributed to the present difficulties of the insured. They are, first, the doctrine of freedom of contract between parties on an equal footing, and, second, the premise that insofar as the risk is concermed, the insured knows everything and the underwriter knows nothing. These premises have long since ceased to correspond to reality, but have been perpetuated mainly by judicial adherence to precedent.

The average insurance consumer has rarely, if ever, enjoyed a strong economic position from which to negotiate the terms of his insurance contract. What room to negotiate he might have enjoyed historically has disappeared in an age of huge insurance companies and "fine print" standard policies. Consequently any meaningful protection for the insuring public must depend upon statutory regulation of policy terms and conditions. Although some legislation exists, ${ }^{38}$ improvements are needed.

${ }^{30}$ Hasson, supra, n. 26 at 38.

3t Insurance Acts: R.S.A. 1970, c. 187, s. 240; R.S.B.C. 1960, c. 197, s. 123(1); R.S.M. 1970, c. I-40, 8. 160; R.S.O. 1970 , c. 224 , 8. 157.

32 Becker v. Marshall (1922) 12 L1. L. Rep. 413; Ewer v. National Employers Mutual Gen. Ins. Ass. Ltd. supra, n. 5; Roberts v. Avon Ins. Co. [1956] 2 Lloyd's Rep. 240.

33 Glicksman v. Lancashire and Gen. Ass. Co. supra, n. 17 which aff'd. the decision of Court of Appeal at [1925] 2 K.B. 593.

34 Schoolman v. Hall [1951] Lloyd's Rep. 139 (C.A.); Regina Fur Co. v. Bossom [1951] 2 Lloyd's Rep. 466; Roselodge Ltd. v. Castle (1966) 2 Lloyd's Rep. 113.

3s Horne v. Poland [1922] 2 K.B. 364; Becker v. Marshall supra, n. 32.

36 Id.

37 Keeton, Insurance Law Rights at Variance with Policy Provisions, (1970) 83 Harv. L. Rev. Part 2961 at 966.

36 Sections in the Insurance Acts of different Provinces of Canada which will be discussed below. 
Furthermore, the device of the "basis clause", the difficulty in obtaining expert testimony on behalf of the insured as to the materiality or otherwise of facts, the legal test of materiality being that of the reasonable insurer, the dearth of legislative protection, and the inability of the judiciary to uniformly construe policies contra proferentem, i.e., against the insurer and in favour of the insured, add to the factors that have increased the difficulties of the insured. These factors have placed the insurer in a strong position to avoid claims under policies, based on the defence of breach of the insured's duty of disclosure.

In addition, the insurer may benefit by an element of surprise in that the effect of the questions in the application form may lead the insured to believe that the former has solicited all the information needed. This can be a dangerous assumption.

In fact, in many cases the insured may not realize until after his claim has arisen that certain alleged facts were material, whereas the insurer, having the vast experience of the insurance industry and a huge inventory of claims experience to rely upon, has been in a position to know all along which facts are material or not. Even so, the insurer is not legally constrained to frame its questions in such a manner as to elicit all the material information needed. The insurer has the added advantage of finding material facts by its own means, that is, through statistical and actuarial surveys, and often by medical examination of the life at risk in the case of life insurance.

The insured is also at a disadvantage when applying for coverage through an insurer's agent since the agent is treated as agent of the proposer, and any non-disclosure or inaccuracy in the answers as a result of intentional or unintentional acts on the part of the agent while completing an application will be attributed to the applicant. The insured must suffer the consequences if he signs the application without reading it or having it properly explained.39

The somewhat precarious position of the insured was well expressed by a Report issued in 1957 by the U.K. Law Reform Committee:40 which had this to say at paragraph four:

... a fact may be material to insurers in the light of great volume of experience of claims available to them, which would not necessarily appear to a proposer for insurance, however honest and careful, to be one which he ought to disclose.

The Committee made the following three recommendations for introducing new provisions into the insurance law of the United Kingdom:

(1) that for the purposes of any contract of insurance no fact should be deemed material unless it would have been considered material by a reasonable insured;

(2) that, notwithstanding anything contained or incorporated in a contract of insurance, no defence to a claim thereunder should be maintainable by reason of any mis-statement of fact by the insured, where the insured can prove that a statement was true to the best of his knowledge and belief;

(3) that any person who solicits or negotiates a contract of insurance should be deemed for the purposes of formation of the contract, to be the agent of the insurers, and that the knowledge of such person should be deemed to be the knowledge of the insurers.

It is unfortunate that these recommendations have not received legislative attention thus far. It has yet to be seen whether in the future any legislative reforms will be introduced to protect the insuring public

39 Newsholme Bros. v. Road Transport and Gen. Ins. Co. [1929] All E.R. 442.

40 U.K. Law Reform Committee, Fifth Report, para. 4 (1957). 
and to restore a measure of equilibrium to the bargaining position of the parties to insurance contracts.

\section{HISTORICAL DEVELOPMENT OF UBERRIMA FIDES- THE CANADIAN EXPERIENCE}

The duty of disclosure in Canada has been modified by statute and the insured is now better protected than his counterpart in England. The insured is, however, still confronted by difficulties in complying with his duty to disclose material facts in certain areas.

A. Difficulties faced by an insured

First, the test of what is material depends, at common law, upon the viewpoint of the reasonable insurer. This test has not so far been modified by statutory provisions. The result is that the limited protection afforded by statutory conditions and other sections in the substantive law portions of the provincial Insurance Acts has not alleviated the problems encountered by consumers of insurance. The insured pays the premium and is taken by surprise when the insurance company denies his claim on the pretext of non-disclosure or misrepresentation of what it alleges to be material facts. The problem arises because the materiality of facts required to be communicated is judged from the insurer's point of view, which is unknown to the insured at the time of effecting insurance. Moreover, no effective steps are being taken to remedy this situation.

Although the courts, in interpreting and applying the doctrine of disclosure, have endeavoured to protect the interest of the insured, the application of the reasonable insurer's test of materiality has produced harsh results inasmuch as the insurer, by calling its own officials to testify, may establish that the facts in question were material from its point of view.42 In the absence of legislation requiring the test of materiality to be that of a "reasonable insured", the judiciary cannot sufficiently protect the interest of consumers of insurance in this area.

The problem, however, seems to have been aggravated by the recent decision of the Supreme Court of Canada in Henwood v. Prudential Ins. Co. ${ }^{43}$ The court in this case did not require the insurer to establish that its view of what is material is in conformity with reasonable practice in the insurance industry. Ritchie J. observed that it was sufficient that there was no evidence to the effect that the practice of the insurance company was unreasonable or that other insurers would have followed a different practice. ${ }^{44}$ This places a heavy onus on the plaintiff to prove the unreasonableness of an insurer's practice. The insured is generally unable to engage the services of independent insurance expert witnesses due to his relatively weak financial position, and, therefore, is not in a position to discharge the heavy burden placed upon him. ${ }^{45}$

It is submitted that the reasonable insurer's test is not at all desirable because an insured does not know what facts the insurer regards as material. If this test is to be used, it should be required that the insurer

11 Id. at para. 14, sub-para. 1, 2

12 Henwood v. Prudential Ins. Co. [1967] S.C.R. 720, (1967) 64 D.L.R. (2d) 715, affirming the Ontario Court of Appeal (unreported), which aff'd. [1965] I.L.R. 1-154; Murphy v. Sun Life Assurance Co. (1964), 44 D.L.R. (2d) 369 (Alta. CA.).

43 Henwood v. Prudential Ins. Co. n. 42.

1 Id. at 727-28.

4s Supra, n. 20 at 631 . 
prove that its practice is in harmony with reasonable practice in the insurance industry. Since the insurer's officers are interested witnesses and susceptible to giving biased testimony, it is submitted that the evidence of expert witnesses not employed by the insurer, and preferably drawn from the insurance industry and Insurance Bureau of Canada, be used to show the reasonableness or otherwise of the practice in question.

The second area in which the insured is faced with a problem in complying with his duty of disclosure involves the completion of proposal forms by the insurer's agent. The applicant usually trusts that the agent is fully equipped with a knowledge of insurance matters and therefore normally allows the latter to complete the application form. The agent of an insurance company in completing a proposal form for an applicant is treated as the applicant's agent and not as acting on behalf of the insurer, ${ }^{46}$ despite the fact that an agent solicits business for the insurance company and is remunerated by it. The agent, therefore, acts for both parties at once, putting him into a conflict of interest situation as well as making him a "legal schizophrenic". The agent is also interested in completing an application form because he has an interest in earning his commission. Where the insured represents truthfully all the material facts solicited, but the agent intentionally or unintentionally fills in incorrect answers and the applicant signs the proposal form in good faith without reading the same, he suffers the consequences of non-disclosure or misrepresentation made by the agent. ${ }^{47}$ This is highly unsatisfactory and calls for suitable statutory amendments. The duty of the insured to disclose material facts through the insurer's agent will be discussed in further detail later.

Thirdly, the defence of innocent non-disclosure or misrepresentation has not been completely abolished. While innocent non-disclosure is no longer a defence under the present statutory conditions in fire insurance, ${ }^{48}$ the insured is subject to this defence in life insurance. Any innocent non-disclosure of material facts in an application for life insurance or on medical examination has the effect of avoiding insurer's liability under the contract. ${ }^{49}$ Conversely, the defence of innocent misrepresentation is available to an insurer in fire and life insurance, but not in automobile insurance. This demonstrates the non-uniformity of legislation in different branches of insurance, the confused state of the law, and the ineffectiveness of the steps taken to sufficiently protect the interest of consumers of insurance. So long as the defence of innocent non-disclosure or misrepresentation is available to insurers, any meaningful reform of the law will not be possible. This will be discussed in detail below.

Fourthly, the "basis of contract clause" has been used in the past as a weapon against the insured, and insurers have been successful in avoiding liability although the omission or inaccuracy in the statements in question was not material. By statute, no contract of insurance in Canada can now be avoided by reason of any inaccuracies in the statements unless material.50 In view of the test of materiality being that

\footnotetext{
4s Newsholme Bros. v. Road Transport and General Ins. Co., supra, n. 39; Roceo v. Northwestern Nat. Ins. Co. [1930] 1 D.L.R. 472, 64 O.L.R. 559.

47 Id. at 442

4s To be discussed further below.

¿ Murphy v. Sun Life Assurance Co., supra, n. 42.

so Supre, n. 28 8. $194(7)$, etc.
} 
of a "reasonable insurer" as discussed earlier, the basis clause still operates against the insured.

\section{B. Statutory regulation and modification of duty of disclosure}

It is now intended to deal with the statutory regulation of the duty of disclosure in the provincial insurance legislation in Canada. In the following discussion, Alberta, British Columbia, Manitoba and Ontario will serve as examples and mention will also be made of Quebec enactments where appropriate. The Alberta legislation will be used as a prototype.

The duty to disclose material facts in fire insurance is contained in section 223 , statutory condition 1 , Alberta Insurance Act, 1970,51 as follows:

If any person applying for insurance falsely describes the property to the prejudice of the insurer, or misrepresents or fraudulently omits to communicate any circumstance which is material to be made known to the insurer in order to enable it to judge of the risk to be undertaken, the contract shall be void as to any property in relation to which the representation or omission is material.

Similar legislation exists in other provinces. ${ }^{52}$

It is submitted that the insertion of the words "fraudulently omits" has abolished the strict doctrine of uberrima fides so far as nondisclosure of material facts in fire insurance is concerned. Innocent nondisclosure of material facts will not avoid the policy. Surprisingly, the legislature has not deemed it desirable to extend this necessity for fraud to misrepresentations. Thus an innocent misrepresentation by the insured will allow the insurer to escape liability whereas an innocent nondisclosure will not, resulting in a rather puzzling disparity. Apparently, this legislation requires the courts to make fine distinctions between non-disclosures and misrepresentations innocently made-a task which may be difficult to accomplish. The case law on this distinction may now be examined.

In Taylor v. London Assurance Corp.,53 it was held that the word "fraudulently" before the word "omits" connotes "actual fraud". Duff C.J. of the Supreme Court of Canada, in a majority judgement made the following observations: ${ }^{54}$

... the adverb 'fraudulently' connotes actual fraud .... We are not concerned with frauds consisting in a breach of duty arising out of fiduciary relation; and it is too plain for argument that if the term 'fraudulently' is used in this statutory condition to describe an innocent breach of the duty to disclose material facts which rests upon the insured under a contract of insurance, then the amendment of the condition effected by the legislation of $14 \mathrm{Geo}$. V. was merely pleonastic.

In that case the plaintiff's wife, acting as his agent in securing fire insurance on his lumber camp, stated that there were fires all over the country without disclosing that there were fires in an adjoining township. The non-disclosure was held not to be fraudulent. The insurance company could not succeed as it failed to prove fraudulent omis. sion.

It was also held that a misrepresentation, innocent or otherwise, in order to negative the insurer's liability under a fire insurance policy,

\footnotetext{
si R.S.A. 1970, c. 187.

32 Insurance Acts: R.S.B.C. 1960, c. 197, 8. 208(1); R.S.M. 1970, c. I-40, 8. 142(1); R.S.O. 1970, c. 224, s. 122(1).

s. Supre, n. 9 .

s4 Id. at 425 .
} 
must be one which influenced the insurer to enter into the contract. It was held that the statement made by Mrs. Taylor did not have any such effect on the mind of insurer's agent.

In Bowes v. Fire Insurance Co. of Canada, 55 the plaintiff, either himself or through the agent, had represented to the insurer that his previous policies of fire insurance with other insurers had lapsed or expired when, as a matter of fact, they were cancelled for non-payment of premium. It was held that this was a misrepresentation of a fact material to the insurer in order to enable it to assess the risk to be underwritten.

It is evident that an innocent misrepresentation would be fatal to recovery under a fire insurance contract whereas an innocent nondisclosure would not.

In Ginsberg v. New York Fire Ins. Co. ${ }^{56}$ the trial court ruled that a defendant, in order to establish fraudulent omission, must assert it in the same manner required of a plaintiff in an action for deceit. In that case the plaintiff had failed to disclose previous claims for fire losses and cancellation of fire insurance policies, but alleged the omission was inadvertent. The defendant failed to prove fraudulent omission and the plaintiff was successful. The court had difficulty in understanding what the Supreme Court of Canada meant by "actual fraud" in the Taylor case. Under the uberrima fides doctrine, an innocent failure to disclose a material fact, or an innocent misstatement of fact, constitutes fraud at common law. A legal fraud, therefore, under the common law could be unintentional, but under the statutory provisions in Canada it must be an "actual fraud".

In Kadishewitz v. Laurentian Ins. Co.,57 the plaintiff had verbally applied for insurance coverage. Since he was not asked for any information concerning the risk, it was held that there was no fraudulent concealment or non-disclosure rendering the policy void. The insured had failed to disclose a fire claim previously made on another insurer and the consequent cancellation of policy following payment for loss.

In summary, as regards fire insurance, section 223(1) of the Alberta Insurance Act 58 has the effect of removing the common law defence of innocent non-disclosure previously available to the insurer. Why it does not do the same for innocent misrepresentation is far from clear.

It may be noted that a misrepresentation as to a part of the property insured against fire avoids the policy as to that part only. The policy will be effective for every other item in the policy. Similar protection is not afforded to an insured in England.59

Section 220 of the Alberta Insurance Act, provides:60

(1) No insurer shall make a contract covering property situated outside the limits of a city, town or village for a term exceeding 12 months, without a written application therefor, signed by the applicant, or, in case of the absence of the applicant or his inability to make an application, by his agent or by a person having an insurable interest in the property.

(2) Every aforesaid written application shall set out the name, address and occupation

ss (1936) 3 I.L.R. 430 (Ont. S.C.).

56 [1937] 4 D.L.R. 585, [1937] O.R. 715.

57 [1931] O.R. 529, [1931] 4 D.L.R. 402 (C.A.).

so Supra, n. 51.

so Harten v. Grenville Patron Mutual Fire Ins. Co. [1938] O.R. 500, 5 I.L.R. 87.

so Supra, n. 51. It appears tha other provinces have not promulgated similar legislation. 
of the applicant, the description, location and occupancy of the property to be insured, its value, particular of any mortgage, lien or other encumbrance thereon, the purpose for which and the location in which any moveable property is deposited or used, particulars of all previous fire claims made by the applicant together with the name of the company or companies against whom the claims were made, whether any insurer has cancelled any fire policy or refused fire insurance to the applicant and such other information as the insurer may require.

In automobile insurance, the duty to disclose material facts is embodied in section 287 of the Alberta Insurance Act ${ }^{61}$ which provides as follows:

(1) Where,

(a) an applicant for a contract,

(i) gives false particulars of the described automobile to be insured, to the prejudice of insurer, or

(ii) knowingly misrepresents or fails to disclose in the application any fact required to be stated therein.

... a claim by the insured is invalid and the right of the insured to indemnity is forfeited.

Other provinces have promulgated similar legislation. ${ }^{62}$

Failure to disclose or misrepresentation must be made "knowingly".

In the case of life insurance, disclosure of material facts is regulated by sections 240 and 241 of the Alberta Insurance Act, $1970 .{ }^{63}$ Section 240 reads:

(1) An applicant for insurance and a person whose life is to be insured shall each disclose to the insurer in the application, on a medical examination, if any, and in any written statements or answers furnished as evidence of insurability, every fact within his knowledge that is material to the insurance and is not so disclosed by the other.

(2) Subject to section 241 , a failure to disclose or misrepresentation of, such a fact renders the contract voidable by the insurer.

The incontestability clause in section 241 provides:

(1) This section does not apply to a misstatement of age or to disability insurance.

(2) Subject to subsection (3) [dealing with group insurance] where a contract has been in effect for two years during the life time of the person whose life is insured, a failure to disclose, or a misrepresentation of, a fact required to be disclosed by section 240 does not, in the absence of fraud, render the contract voidable.

The legislatures of other provinces have made corresponding provisions in their Insurance Acts. ${ }^{64}$

It should be noted that the burden of proving fraud on the part of the insured is on the insurer and that the interest of the insured is protected after a term of two years in a life insurance policy despite his nondisclosure or misrepresentation of material facts within his knowledge.

Another example of the statutory protection extended to the insured is incorporated in section 243 of the Alberta Insurance Act ${ }^{65}$ regarding misstatement of age, which does not render the contract voidable but allows the insurance money to be increased or decreased to the amount that would have been provided for the same premium at the correct age. The subsection reads:

\footnotetext{
is Supra, n. 51.

62 Insurance Acts: R.S.B.C. 1960, c. 197, s. 225(1); R.S.M. 1970, c. I-40, a. 236(1);R.S.O. 1970, c. 224, 8. 204.

6. Supra, n. 51.

64 Insurance Acts, R.S.B.C. 1960, c. 197, s8. 123(1) \& (2); R.S.M. 1970, c. I-40, 88. 160(1) \& (2) and 161(2); R.S.O. 1970 , c. 224, 83. 157 \& $158(2)$.

as Supra, n. 51.
} 
243(2) ... where the age of a person whose life is insured is misstated to the insurer, the insurance money provided by the contract shall be increased or decreased to the amount that would have been provided for the same premium at the correct age.

Similar provision is to be found in other provincial Insurance Acts. ${ }^{66}$

Mention may also be made, at this stage, of a general provision enshrined in section 194(7) of the Alberta Insurance Act ${ }^{67}$ which provides:

No contract of insurance shall contain or have endorsed upon it, or be made subject to any term, condition, stipulation, warranty or proviso providing that the contract shall be avoided by reason of any statement in the application therefor or inducing the entering into of the contract by the corporation, unless the term, condition, stipulation, warranty or proviso is limited to cases in which the statement is material to the contract, and no contract shall be avoided by reason of the inaccuracy of any such statement unless it is material to the contract.

This provision has the happy effect of providing that the use of the "basis of contract clause" or warranty cannot help the insurer in avoiding the liability under the contract unless it can be shown that the inaccuracy in the statement(s) was material. In other words, a breach of warranty, condition or term is not fatal to contract unless material to the contract.

Section 194(9) provides: ${ }^{68}$

Nothing in this section impairs the effect of any statutory condition required by this Act to be inserted in any contract of insurance or of any express provision of this Act.

Reading this provision together with section 287(a)(ii) poses a problem. The combined effect seems to be that under section 287 a misrepresentation or misdescription made knowingly or wilfully will forfeit a claim, whether it be material or not, unless it can be argued that a "fact required to be stated" in the application is always material.

Legislation corresponding to section 194(7) of the Alberta Insurance Act exists in other provinces. 69 However, in British Columbia, section $14(1)^{70}$ extends protection not only to inaccuracy in any statements but also to non-disclosure. The section reads:

No contract is rendered void or voidable by reason of any misrepresentation, or any failure to disclose on the part of the insured, in the application or proposal for insurance or otherwise unless the misrepresentation or failure to disclose is material to the contract.

It is submitted that all statutes should cover non-disclosure as well.

The question of materiality in any contract of insurance is a question of fact for the jury, or if there is no jury, for the court to decide. This has been enacted in section 194(8) of the Alberta Insurance Act. ${ }^{71}$ The section reads:

The question of materiality in any contract of insurance is a question of fact for the jury, and no admission, term, condition, stipulation, warranty or proviso to the contrary contained in the application or proposal for insurance, or in the instrument of contract, or in any agreement or document relating thereto has any force or validity.

so Insurance Acts; R.S.B.C. 1960 , c. 197, 88. 126(1) \& (3); R.S.M. 1970, c. I-40; 8. 163(2); R.S.O. 1970, c. 224, 8. 160(2).

67 Supra, n. 51.

6s Id.

69 Insurance Acts: R.S.B.C. 1960, c. 197, 8. 14(1); R.S.M. 1970, c. I-40, 8. 117(4); R.S.O. 1970, c. 224, s. 98(5).

70 Insurance Act, R.S.B.C. 1960, c. 197.

"Supra, n. 51. 
Equivalent legislation is to be found in other provincial Insurance Acts, ${ }^{72}$ although British Columbia and Manitoba omit the phrase "for the jury, or for the court if there is no jury", from their sections. The legal test of materiality, however, is whether the matter would in fact influence the reasonable insurer in the sense that he would either reject the risk or stipulate a higher rate of premium.

\section{Criticism of statutory provisions}

The statutory provisions discussed earlier have been enacted by legislatures with the apparent intention of protecting the interest of an innocent insured, but the drafting in different parts of the Insurance Acts is not uniform and even in particular parts of the Acts, there are different standards prescribed. It seems that the draftsmen are not clear in their minds as to the present common law position and as to the results to be achieved. Unless there are plausible grounds for different standards, it is felt that the present lack of uniformity in the various statutory provisions is completely untenable.

In fire insurance, statutory condition 1 under section 223 of the Alberta Insurance Act and similar legislation in other provinces, ${ }^{73}$ provide for a fraudulent omission of material facts to render a contract void. If, however, the fraudulent omission affects only a part of the property, the entire contract is not void, but is avoided only as to any property in relation to which the fraudulent omission is made. Several comments may be made here. First, it is very difficult for an insurer to prove fraud on the part of an insured and the latter may successfully evade the insurer's defence by showing that he inadvertently forgot to mention the material facts. This is evident from the case of Ginsberg v. New York Fire Ins. Co., briefly discussed earlier. ${ }^{74}$ Secondly, an insured may benefit by his own fraud because if it does not affect the entire contract the insured can still recover in respect of property not affected. Is this not an inducement to an intelligent but dishonest insured to commit fraud on the insurer with the idea that if it is discovered, he will be protected as to the rest of the property?

An insured who makes a misrepresentation in an application for fire insurance is differently placed. According to statutory condition 1 referred to above, even an innocent misrepresentation will have the effect of avoiding the policy as to property in relation to which the misrepresentation is made. To avoid a fire insurance policy, an omission must be fraudulent, but a misrepresentation may be innocent. It may be speculated that the reason for making an innocent misrepresentation a ground for avoiding liability in fire insurance is that the insurer in accepting the insurance may be influenced by the misrepresentation made, whereas it does not have anything to rely on in case of nondisclosure of a material fact. Even this argument is not tenable when the problem is considered in its broader perspective; e.g., an insured may innocently represent that he had only one fire whereas in fact he had two fires on the property, the fire not disclosed having taken place a long time ago. The contract will be void for innocent misrepresentation. Where, however, the insured innocently omits to disclose both the fires, he can still recover because the omission was not fraudulent within the

\footnotetext{
72 Insurance Acts; R.S.B.C. 1960, c. 197, s. 14(2); R.S.M. 1970, c. 1-40, 8. 117(5); R.S.O. 1970, c. 224, 8. 98(6),

${ }^{73}$ Supra, n. 51, 52

74 Supra, n. 56.
} 
meaning of section 223 , statutory condition 1 . This result is possible despite the fact that the insurer is prejudiced more on account of the non-disclosure of two fires than by the misrepresentation as to one fire. This anomaly is not justified unless it is supported by cogent reasons, which do not readily appear.

Moreover, statutory condition 1 is silent as to the effect of fraudulent omission or misrepresentation of material facts which do not relate to the property but which may have a bearing on the acceptance of the risk, i.e., moral hazard. ${ }^{75}$

The wording of the statutory condition is very wide in view of the fact that it does not specifically make clear that the duty to disclose material facts only arises in response to direct questions in the application form. Where a question on a material fact is not asked the insured is still under a duty to make full disclosure. However, an insurer will have to prove fraudulent omission in order to avoid the policy. This may be illustrated by cases where questions relating to incendiarism are not asked in the application for insurance, but the insurer can still avoid liability by showing fraudulent omission. The statutory condition should make it clear that the duty to make full disclosure arises only in connection with specific questions asked.

In automobile insurance, misrepresentation or failure to disclose must be made "knowingly" under section 287 of the Alberta Insurance Act,76 and its corresponding legislation in other provinces. ${ }^{77}$ The standard prescribed for the act or default is the same i.e., actual knowledge.

The word "knowingly" rules out any possibility that an insurer may avoid a contract for innocent non-disclosure or misrepresentation. Insurers, in order to be successful, must prove not only misrepresentation but also knowledge of material facts on the part of the insured. In fire insurance, under statutory condition 1 of section 223 of the Alberta Insurance Act and similar provisions in other provincial Insurance Acts, ${ }^{78}$ a contract can be avoided for innocent misrepresentation. In life insurance, under section 240 of the Alberta Insurance Act and corresponding legislation in other provinces, ${ }^{79}$ an insurer can repudiate the contract for innocent non-disclosure or misrepresentation. Section 287 and its equivalent legislation is, therefore, to be preferred as it provides that non-disclosure or misrepresentation must be made "knowingly". But it is submitted that this section is not entirely satisfactory because it does not require non-disclosure or misrepresentation in bad faith in the sense that the applicant knows about the materiality of the facts not disclosed or misrepresented. Materiality is judged solely from the insurer's point of view. It is suggested that only non-disclosure or misrepresentation made in bad faith with actual knowledge of materiality of facts on the part of the insured should be allowed to affect the validity of the policy or a claim thereunder.

An insured in automobile insurance is under a duty to disclose "in the application any fact required to be stated therein". This, if strictly interpreted, may suggest that upon renewal the insured is under a duty

\footnotetext{
75 Heighington, Fire Insurance-Fraud and Misrepresentation-Statutory Condition 1-Summary of Recent Cases, (1956) 34 Can. Bar Rev. 93 at 100.

${ }^{76}$ For text of the section, see supra, n. 61.

77 Supra, n. 62.

78 Supra, n. 51, 52.

79 Supra, n. 63, 64.
} 
to disclose material facts, occurring after the issuance of the original policy, only when an insurer requires a de novo application. If the insurer fails to require a fresh application, the insured, perhaps, has no duty of disclosure! This point should be clarified. It is suggested that the law should provide that where the insurer fails to require a renewal application it should be deemed to renew on the basis of information contained in the original application, and should be precluded from using the defences which rely upon changes in material circumstances about which it has not seen fit to enquire.

Where an insured knowingly misrepresents or fails to disclose a fact required to be stated in the application, the contract is not avoided but a claim by the insured is invalid. The insurer, in such a case, may be in a position to retain the premiums paid by the insured. In fire insurance, a contract is void even for an innocent misrepresentation and a court may, in such a case, ask the insurer to return the premiums because the contract is unenforceable. However, an insured cannot recover a claim under the policy where he commits fraudulent omission of material facts in fire insurance. He may not be in a position to recover premiums paid if following a fraudulent omission he brings an action against the insurer. This is based on the premise that an insured cannot make his own fraud a basis of claim, as is the case in England. ${ }^{80}$

Section 287 of the Alberta Insurance Act provides that "a claim by the insured is invalid". This seems to give the impression that a person other than the insured, e.g., a third party accident victim, is protected in the event of a misrepresentation or a failure to disclose material facts. This is not necessarily so. The issue will be discussed in detail in the second chapter.

In life insurance, under section 240 of the Alberta Insurance Act, as discussed earlier, ${ }^{81}$ a failure to disclose or an omission may be innocent. This will render the contract voidable at the instance of the insurer and the insured may be unable to recover the premiums paid.

We may summarize this discussion by saying that an omission must be "fraudulent" in fire insurance, made "knowingly" in automobile insurance, but may be "innocent" in life insurance. Conversely, misrepresentations must be made "knowingly" in automobile insurance but may be innocent in fire and life insurance. In all circumstances, the insured will be unable to recover indemnity with perhaps different results as to the return of his premium.

Statutory condition 1 relating to fire insurance and section 240 dealing with life insurance provide that omissions or misrepresentations must be of material facts whereas section 287 dealing with automobile insurance does not talk about materiality. It provides for omission or misrepresentation of "any fact required to be stated" in the application for insurance. This seems to give an impression that misrepresentation or misdescription make knowingly or wilfully will forfeit a claim whether it be material or not, unless it can be conclusively established that every fact required to be stated automatically becomes material.

Statutory condition 1 and section 240 , due to unclear drafting, seem to give an impression that an insured in fire and life insurance may be

\footnotetext{
${ }^{80}$ Gibbs C.J. in Feise v. Parkinson (1812) 4 Taunt. 640 at 641; Parke B. in Anderson v. Thoronton (1853) 8 Ex. 425.

si Supra, n. 63.
} 
under a strict duty to disclose material facts although a particular question is not asked. In automobile insurance, the language of section 287 is clear and an insured is under no obligation to make such disclosures.

The duty of disclosure in fire insurance is to be found in a statutory condition whereas the same requirement in automobile and life insurance has been enacted in the substantive portions of the provincial Insurance Acts. ${ }^{82}$

In the absence of some clear intention of the Legislatures, such a treatment of the duty of disclosure is puzzling.

Legislatures have deemed it desirable to make life insurance contracts incontestable after they have been in effect for a period of two years during the lifetime of the insured. This is so only in the absence of fraud on the part of the insured.83 This protection can be extended to fire and automobile insurance contracts. Since these are not long term contracts, it is suggested that they may be made incontestable after they have been in force for a period of six months. This is desirable not only from the insured's point of view but also from the viewpoint of third persons who suffer injuries or property damage as a result of automobile collision. Moreover, the insurer has a reasonable period of time to investigate the risk.

The Association of Superintendents of Insurance of the provinces of Canada meet from time to time to discuss, inter alia, uniformity in the different provincial Insurance Acts. ${ }^{84}$ Their efforts could profitably be directed toward clearing up the present lack of uniformity and cohesiveness in each of the provincial insurance statutes in the important area of the duty of disclosure. It is suggested that it is difficult for the courts to make headway in an area where the legislation appears confused or inadequate.

\section{NON-DISCLOSURE AND MISREPRESENTATION- MODERN CASE LAW}

The case law on non-disclosure and misrepresentation will receive a separate treatment in the following discussion. Where, however, the courts have not made a distinction between the two, they will be dealt with under a general heading.

A. Fire insurance

1. Non-disclosure

Statutory condition 1 relating to fire insurance, as in force in different provinces, provides: ${ }^{85}$

If any person applying for insurance falsely describes the property to the prejudice of the insurer, or misrepresents or fraudulently omits to communicate any circumstance which is material to be made known to the insurer in order to enable it to judge of the risk to be undertaken, the contract shall be void as to any property in relation to which the misrepresentation or omission is material.

Before entering into a discussion of the case law on non-disclosure, it appears pertinent to examine the predecessor of condition 1 , which was repealed in Alberta in 1926, and to note the effect of the substituted

\footnotetext{
s2 Supra, n. 51, 52, 61-64.

su Supra, n. 63, 64.

as See Proceedings of Meetings of the Association of Superintendents of Insurance of the Provinces of Canada.

as Insurance Acts: supra, n. 51, supra, n. 90, 208(1), R.S.M. 1970, c. I-40, s. 142(1); R.S.O. 1970, c. 224, s. 122(1).
} 
legislation. Other provinces have made similar amendments. ${ }^{86}$ Prior to the repeal, the statutory condition stipulated that a fire insurance policy could be avoided if the applicant "misrepresents or omits to communicate any circumstance which is material to be made known to the company." "87

It may be noticed that a significant change introduced by the substituted legislation is the inclusion of the word "fraudulent" before the word "omits". This has the effect of removing the defence of innocent non-disclosure from the insurer. Although this has resulted in the protection of the interest of the innocent insured, it has in some instances produced harsh results where an insured has deliberately failed to disclose material facts, but the insurer has been unable to establish fraudulent omission. This will be made amply clear from the case law. It is submitted that the statutory condition should act in fairness both to the insured and the insurer. After discussion of the case law, suggestions for reform will be made.

\section{(a) Fraudulent omission generally}

The most authoritative pronouncement on the interpretation of the word "fraudulently" is to be found in the leading case of Taylor v. London Ass. Corp. ${ }^{88}$ Duff C.J., in a majority judgement of the Supreme Court of Canada, observed:89

... the adverb "fraudulently" connotes actual fraud ... if the term "fraudulently" is used in this statutory condition [one ${ }^{90}$ ] to describe an innocent breach of the duty to disclose material facts which rests upon the insured under a contract of insurance, then the amendment of the condition effected by the legislation of 14 Geo. V. was merely pleonastic.

The facts leading to the case were that Mrs. Taylor, while applying for fire insurance on camp buildings and equipment owned by her husband, told the insurer's authorized agent over the telephone that there were fires all over the country without disclosing that there were fires in McNish, the adjacent township, a fact which she herself did not know. The insurer disclaimed any intentional wrongdoing on behalf of the plaintiff and his wife. Duff C.J., in the course of his judgement, stated on this ground that, "... the course of litigation precludes the respondent from relying upon the charge of fraud. No such charge was pleaded."91

The case has settled the law that non-disclosure of material facts in an application for fire insurance, must be fraudulent to render the policy void. The case was followed inGinsberg v. New York Fire Ins. Co. ${ }^{92}$ and Salata v. Continental Ins. Co. ${ }^{93}$ although McTague J. of the Ontario Supreme Court, in the latter case, expressed surprise at the holding of the Chief Justice of Canada, for reasons to be discussed in the following paragraphs.

The Taylor case leads to the conclusion that an inadvertent and un-

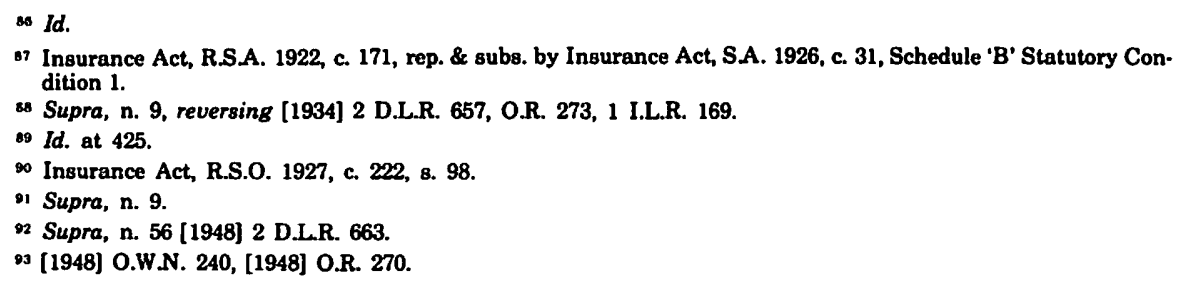


intentional omission of a fact material to the risk does not fall within the purview of "fraudulent" omission.

\section{(b) Inadvertent omission}

In Ginsberg v. New York Fire Ins. Co.,94 the plaintiff admitted his omission to disclose prior refusal of coverage by another insurer, which he knew to be material, and successfully contended that the omission was inadvertent and therefore not fraudulent, within the meaning of section 98 of the Ontario Insurance Act ${ }^{95}$ which provided:

If any person applying for insurance falsely describes the property to the prejudice of the insurer, or misrepresents or fraudulently omits to communicate any circumstance which is material to be made known to the insurer in order to enable it to judge of the risk to be undertaken, the contract shall be void as to the property in respect of which the misrepresentation or omission is made.

McTague J., of the Ontario Supreme Court, while referring to the leading case of Taylor v. London Assurance Corp. ${ }^{96}$ remarked on the findings of Chief Justice Duff thusly: ${ }^{97}$

... I have difficulty in understanding just what the Chief Justice of Canada meant by the expression 'actual fraud'.. . the word 'fraudulently,' in my opinion, should not be construed so as to put upon a defendant the burden of proving what a plaintiff would have to prove in an action for deceit. To do that is to change the whole fundamental law applying to insurance, and to say that the doctrine of uberrima fides has no application, ... the amendment of the condition was merely pleonastic."

In the opinion of McTague J., where an insurer proves that the insured conceals any fact which he knows to be material, the result is fraud. He has suggested that the doctrine of uberrima fides has not been abolished and that the effect of the amendment was only pleonastic. After expressing this opinion, the judge nevertheless felt himself bound by the decision in Taylor v. London Ass. Corp. The Ginsberg case tells us that if the insured can establish to the satisfaction of the court that the omission of a fact known to him to be material was inadvertent or unintentional, this will not constitute a "fraudulent" omission within the meaning of statutory condition 1 .

The reader may note, at this stage, that the Legislature of Alberta, by enacting section $220(2)$ of the Insurance Act, ${ }^{98}$ regards the prior refusal of fire coverage to be a material fact, the fraudulent omission or misrepresentation of which will avoid the policy. The subsection provides:

(2) Every aforesaid written application shall set out the name, address and occupation of the applicant, the description, location and occupancy of the property to be insured, its value, particulars of any mortgage, lien or other encumbrance thereon, the purpose for which and the location in which any moveable property is deposited or used, particulars of all previous fire claims made by the applicant together with the name of the company or companies against whom the claims were made, whether any insurer has cancelled any fire policy or refused fire insurance to the applicant and such other information as the insurer may require.

The predecessor to this section was enacted in $1927^{99}$ and appears to be a unique piece of legislation inasmuch as other provinces do not seem to have a similar provision.

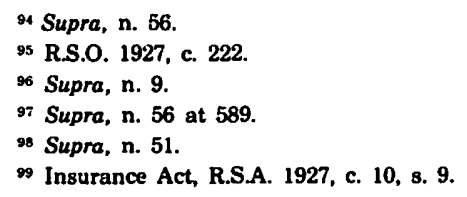




\section{(c) Omission in written application}

Under section 220(1) of the Alberta Insurance Act, 100 a contract for fire insurance cannot be entered into without a written application, signed by the applicant or by his agent. The subsection provides:

No insurer shall make a contract covering property situated outside the limits of a city, town or village for a term exceeding 12 months, without a written application therefor, signed by the applicant, or, in case of the absence of the applicant or his inability to make the application, by his agent or by a person having an insurable interest in the property.

The predecessor to this section was enacted in $1927 . .^{101}$ It appears, however, that in British Columbia, Manitoba and Ontario, a written application for fire insurance is not required by the statute. ${ }^{102}$

The effect of an omission to disclose material facts where no specific question is asked of the applicant may now be examined. In Kadishewitz v. Laurentian Ins. Co., ${ }^{103}$ the insured, who verbally applied for insurance, failed to disclose the occurrence of a fire on the insured property, the settlement of the claim and the cancellation of the fire insurance policy. McEvoy J., of the Ontario Court of Appeal, observed:104

... some of the matters which have been found to exist at the time of application were matters which, if the defendant company before taking the insurance had seen fit to inquire about and if on enquiry the plaintiff had misled the defendant company by any act or omission to believe the facts were otherwise than in reality they were, would under our law [Ontario law] relieve the defendant company of liability.

Riddle, J.A., dealing with the intention of the Legislature in enacting statutory condition 1 , respecting fraudulent omission, remarked:105

... it would be the height of absurdity to suppose that the Legislature, in making the condition mentioned a part of the policy of insurance, meant to give the insurer an additional or cumulative right along with the common law and equity rights he had of voiding the policy for an innocent omission to disclose material facts ... what was intended was to limit these rights by requiring the omission to be fraudulent.

The Kadishewitz case makes it clear that in Ontario, when no question is asked and in the absence of fraudulent concealment, an omission of some of the particulars regarding the property to be insured will not avoid the policy. In contrast, section 220(2) of the Alberta Insurance Act ${ }^{106}$ specifically requires the disclosure of all previous fire claims, cancellations and refusals to insure. Although these very facts were not communicated in the Kadishewitz case, they did not prove fatal to recovery, as would be the case in Alberta.

(d) Previous fires

Failure to disclose a previous fire is material to the risk, but where a question is ambiguously worded and the insured misunderstands the question, failure to disclose a fire may not be fatal to recovery. In Fordorchuk v. Car \& General Ins. Corp., ${ }^{107}$ the applicant was asked a number of questions in the application form. The question immediately

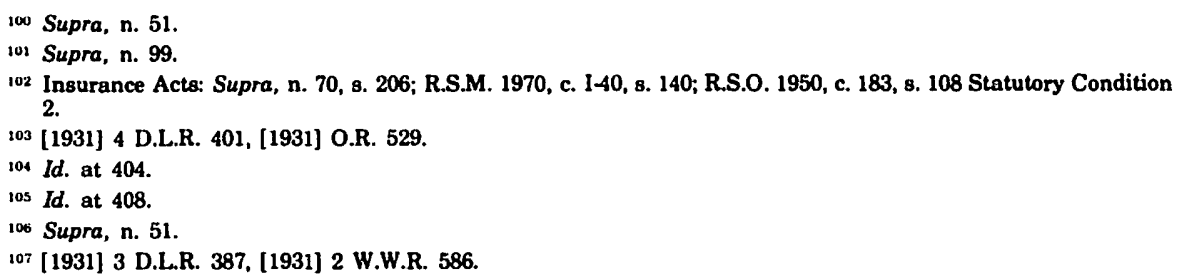


preceding the one relating to previous fires asked if there is any incendiary danger to this property. This question was followed by the question, "Have you ever had a fire?", the only one which concerned matters outside the scope of the property proposed to be insured. The applicant regarded this question as related only to the homestead and answered in the negative. In fact, the insured had had a fire on his other property at a distant place, which he did not disclose in the application. Ewing J., of the Supreme Court of Alberta, discussing the impression that the question conveyed, said: ${ }^{108}$

Any applicant might reasonably infer that this question also related to the homestead and answer it accordingly.... I am unable to find that this was an unreasonable inference to draw from the question. Nor do I think that the plaintiff's failure to disclose on his own initiative a previous fire should tell against him.

The plaintiff was successful on the above ground because the contra proferentem rule was applied, but the policy was avoided on another ground due to non-disclosure of the existence of encumbrances.

This case makes it clear that a question contained in an application for fire insurance asking whether the applicant ever had any property destroyed by fire is material, but an answer thereto which is literally untrue will not have the effect of avoiding the policy, unless the question was unambiguously worded.

In Renshaw v. Ocean Accident \& Guarantee Corp., ${ }^{109}$ the proposer, in applying for insurance on the contents of a dwelling house, failed to disclose, inter alia, the fact of a previous fire loss, and that he held an additional concurrent insurance policy. Neither company was informed about the insurance held in the other company. The present action was brought under the second policy. Hope J., of the Ontario Supreme Court, found that the failure of the insured to disclose a previous fire loss and concurrent insurance policy invalidated the policy. ${ }^{110}$ The insured was allowed to recover only sixty per cent under the first policy because of concurrent insurance with the defendant. The insured was rightly penalized for not disclosing the previous loss, a material fact, and for trying to recover twice under both policies.

In Chapman v. Canadian Accident Fire Ins. Co., ${ }^{11}$ the plaintiff, who placed insurance on an unfinished dwelling house, failed to disclose, among other matters, that he had previously lost property due to arson prompted by ill-feelings in the neighbourhood. The plaintiff knew that the written application was silent as to this fact when he signed the same. Kelly J., of the Ontario Supreme Court, speaking of the importance of the facts withheld, remarked:112

Good faith required that he should have candidly laid all these matters before the defendant company .... He deliberately and intentionally withheld the information from the defendant company so as thereby to obtain the insurance.

The Fordorchuk case represents good law because the ambiguity in the question was construed against the insurance company. In the Renshaw case, however, the insured had failed to disclose a recent fire in the insured property, although there was no complaint of ambiguity in

\footnotetext{
108 Id. at 390.

109 (1941) 8 I.L.R. 182.

$110 \mathrm{Id}$. at 185 .

111 (1929) 37 O.W.N. 320.

112 Id. at 321.
} 
the questions on the application. Rather, the insured was guilty of fraudulent conduct in not disclosing concurrent insurance. In the Chap. man case, the insured knew that in the past his property had been destroyed by incendiarism and feared its occurrence again, but deliberately withheld these facts.

The courts have granted relief from forfeiture in cases where they have found that an insured reasonably drew wrong inferences from ambiguous questions, but they have prevented recovery where the insured is guilty of deliberate withholding of material information or fraudulent conduct.

These cases make it clear that the fraudulent omission of previous fires and claims made are regarded as facts material to the risk, and result in the avoidance of fire insurance policies. There are other cases to this effect.113

\section{(e) Apprehended or threatened incendiarism}

The disclosure of incendiarism, whether apprehended or threatened, is naturally regarded as most material to the acceptance of the risk in fire insurance. There are not many recent cases on the subject. In Chapman v. Accident Fire Ins. Co., 114 the facts of which have been discussed in preceding paragraphs, the insured, while applying for insurance coverage, apprehended incendiarism due to enmity in the neighbourhood, but wilfully concealed that information in order to secure a fire insurance policy. This constituted a fraudulent omission of material facts, and hence, the plaintiff's action against the insurance company to recover under the policy was dismissed. There are also a number of cases on incendiarism in the nineteenth century, 115 which show that if the applicant apprehends danger of incendiarism, he is under an obligation to disclose the apprehended danger, even though the grounds of apprehension may later transpire to have been unfounded. The reason for this required disclosure is that the insurer may be in a position to make investigations of the claim.116

2. Misrepresentation

\section{(a) Misrepresentation generally}

The cases discussed earlier have borne out the fact that nondisclosure must be fraudulent, but the legislatures have not deemed it appropriate to extend this necessity of fraud to misrepresentation. It follows, therefore, that misrepresentation in order to vitiate a policy, must be material but can be less than fraudulent. The cases on this subject may now be examined.

In Slata v. Continental Ins.Co., 117 the insured, to the knowledge of the insurer's soliciting agent, falsely represented that his barn had oil burning equipment for conditioning the tobacco with steam, and that the equipment operated without a chimney; whereas in fact, no such equipment had been purchased or installed. Instead, the insured employed a home-made apparatus of his own contrivance which used wood and coal for fuel. The insured later erected a chimney to go with the apparatus in-

\footnotetext{
${ }_{113}$ Melvin v. B.A. Ass. Co. [1933] 1 D.L.R. 678, (1933) 6 M.P.R. 438, (N.S.C.A.).

"11 Supra, n. 111.

115 Greet v. Citizens' Ins. Co. (1880) 5 OA.R. 596 varying 27 Gr. 121 (C.A.); Findley v. Fire Ins. Co. of North America (1894) 25 O.R. 515 (C.A.); Kinseley v. B.A. Ass. Co. (1900) 32 O.R. 376 (C.A.).

11 Gabel v. Howick Farmers Mutual Fire Ins. Co. (1917) 38 D.L.R. 158, 40 O.L.R. 139.

317 Supra, n. 93.
} 
stalled. The chimney, which was neither existent nor contemplated by the insured or the insurer at the time of issue of the policy, added a new fire hazard involving a material change in the risk. Robertson C.J.O., of the Ontario Court of Appeal, found that the plaintiff had committed a breach of statutory condition 1 and the contract of insurance on the tobacco was void. As to the statutory enactment dealing with misrepresentation, he remarked:118

It is not necessary that, to give effect to Stat. Con. No. 1 of the policy, we should find fraud on the part of the appellant in making the misrepresentations contained in his written application. While it is now necessary to prove fraud, if non-disclosure only is relied upon (see Taylor v. London Ass'ce Corp., [1935] 3 D.L.R. 129; S.C.R. 422, and Kadishewitz v. Laurentian Ins. Co., [1931] 4 D.L.R. 401; O.R. 529), no similar change in the statutory condition, in terms, requires that misrepresentation, to be effective, shall be material, but it need not be fraudulent.

The case of Arnprior v. U.S. Fidelity \& Guarantee Co. ${ }^{119}$ was cited as authority.

In Taylor v. London Assurance Corp., ${ }^{120}$ the plaintiff's wife, as his agent, applied for insurance coverage through the insurer's authorized agent and told him over the telephone that there were fires all over the country without specifically mentioning that there were fires in $\mathrm{McNish}$, the next township, a fact which she herself did not know. Mrs. Taylor's statement, though innocent, would have vitiated the contract if the defendant could have successfully established that the representation was relied upon. Duff C.J., of the Supreme Court of Canada, therefore, made the following observation as to the effect of misrepresentation: ${ }^{121}$

A misrepresentation in the air is of no legal significance ... it must be a misrepresentation influencing the other party to enter the contract ... the witness [the agent of the insurer] does not suggest that anything Mrs. Taylor said to him had any effect on his mind of any description whatever; much less it influenced him in assenting to effect the insurance.

\section{(b) Misrepresentation as to title}

Ownership of property is regarded as a fact material to the acceptance of the risk and any misrepresentation in that regard may affect the validity of the policy. To what extent such misrepresentation as to title affects the insured's right of recovery under the policy may now be examined.

In Marshall v. Wawanesa Mutual Ins. Co., ${ }^{122}$ the insured was a purchaser under an agreement of sale with the Soldier Settlement Board. The plaintiff had signed a blank application form and handed it to the soliciting agent of the insurer, to whom he had verbally explained everything. McDonald C.J.A., of the British Columbia Court of Appeal, held: ${ }^{123}$

... the word 'owner' in the circumstances was not a misrepresentation of his title, not because he had explained his title to the agent, but because he could fairly be described as such.

In yet another case, Tarr v. Westchester Fire Ins. Co., ${ }^{124}$ the plaintiff

114 Id. at 670 .

119 (1915) 51 S.C.R. 94, 21 D.L.R. 343.

120 Supra, n. 9.

121 Id. at 429.

122 [1924] 2 D.L.R. 419, affirming [1923] 3 W.W.R. 418, 32 B.C.R. 419, [1923] 3 D.L.R. 696.

123 Id. at 419.

124 [1952] 2 D.L.R. 281, O.R. 7, I.L.R. 355, aff'd. [1953] O.R. 378, 2 D.L.R. 655, I.L.R. 518 (Ont.C.A.). 
and his wife were purchasers of a tobacco barn under an agreement of sale. The plaintiff, in answer to a question whether he was the sole and unconditional owner of the barn, replied in the affirmative. The defendant contended material misrepresentation. Judson J., of the Ontario High Court, while commenting upon the purchase under agreement of sale and materiality of misrepresentation, observed:125

A person buying under an agreement is an owner ... plaintiff's failure to mention his wife, even if it is a misrepresentation, is not a material one. There was no evidence offered that a reasonable and prudent insurer would have declined the risk or stipulated for a higher premium if it had been shown that the plaintiff's wife had an interest in the property under the agreement. There is, moreover, evidence to the contrary.

These cases demonstrate that a purchaser under an agreement of sale can fairly describe himself as owner of the property without committing a breach of statutory condition 1 and the right of indemnity under the policy in such a circumstance will not be forfeited.

In Barcha v. Atlas Ass. Co., ${ }^{126}$ the insured was a purchaser under an agreement of sale for back taxes on the property. The property, which was the subject of the purchase, was insured by the vendor. The purchaser obtained, through the insurer's agent, a renewal of the policy held by his predecessor in title. No written application was required from the purchaser, but he told the agent, who was also the mayor of the municipality and conversant with the tax arrears on the property, about the sale and his efforts to redeem the property. During the currency of the policy, the insured premises were totally destroyed by fire. Following a claim, the insurer denied liability on the ground of non-disclosure of the tax sale. At the time when the case arose, a written application for fire insurance was not required by the Alberta Insurance Act but statutory condition $1^{127}$ provided:

If any person insured property and ..., or misrepresents or omits to communicate any circumstance which is material to be made known to the company in order to enable it to judge of the risk it undertakes such insurance shall be of no force.

Walsh J., of the Supreme Court of Alberta, discussing the necessity of requiring a written application from the insured, remarked: ${ }^{128}$

... if it [the insurer] had insisted upon it [the written application] there would be no room for doubt as to the information which the plaintiff gave.

The plaintiff was the owner of the property despite the tax sale because he had the right of redemption. Therefore, non-disclosure of the tax sale was not a material fact fatal to recovery. Under section 220 of the Alberta Insurance Act, ${ }^{129}$ an application for fire insurance must be in writing. Subsection (2) now requires the insurer to list questions in the application form regarding any mortgage, lien or other encumbrances. ${ }^{130}$ Any fradudulent non-disclosure or misrepresentation of these facts will now vitiate a fire policy.

\section{(c) Existence of encumbrances}

Insurers regard the existence of encumbrances as material to the risk and normally frame questions in that regard. Where the insured, in

\footnotetext{
123 Id. at 284.

128 [1924] 2 D.L.R. 836, 2 W.W.R. 467.

127 R.S.A. 1922, c. 171, Schedule C.

128 Supra, n. 126 at 840.

129 Supra, n. 51.

130 For text of the section see $n$. 51, supra.
} 
answer to specific questions, gives false statements, he must suffer the consequences of his act, as any claim based on such statements would be void. In Fordorchuk v. Car \& General Ins. Corp., ${ }^{131}$ the plaintiff was asked a question in the application for insurance as to whether or not the property was subject to mortgage and litigation. The plaintiff gave a grossly and obviously untrue answer, stating in the application that the premises were not mortgaged and were not the subject of litigation. In fact, he had placed a mortgage shortly before taking out the policy. Moreover, he had been served with a statement of claim in connection with foreclosure proceedings on another mortgage on the same property. Neither the agent nor the insurance company knew about the correctness or otherwise of the answers as to the above facts. Ewing $J$., of the Alberta Supreme Court, held that "the plaintiff misrepresented the fact of the mortgage and of the litigation to the insured [sic] and that such facts were material to the risk."132 The case was, therefore, dismissed with costs.

\section{(d) Over-valuation}

Matters of valuation of property are questions of opinion and the appraisal thereof by different persons can hardly invariably be the same. Where, however, the insured knowingly makes a false statement as to the valuation of the property, he may be barred from recovery under the policy. If the valuation is stated incorrectly but there is no deliberate attempt on the part of the insured to over-state the value and the insured property suffers total destruction, he is entitled to the return of the premium representing the difference between the sum insured and the appraised value of the property. Section 219 of the Alberta Insurance Act $^{133}$ provides:

(4) In the event of the total destruction of any insured property with respect to which the total amount of insurance money payable is less than the total amount of in. surance thereon, the insurer or insurers shall return to the insured person the total amount of insurance premium paid for the excess of the insurance over the appraised value of the property at the time of the loss, which amount shall be paid to the insured at the time and in the same manner as the loss is paid.

(5) Subsection (4) does not apply

(a) where an insured person has knowingly placed insurance in excess of the insurable value of any building or property or interest therein.

It appears that these provisions are little known and infrequently applied. There appears to be no reported case where the insured was allowed return of premium for excess insurance. Modern case law on this subject is sparse. The following decisions may, however, be examined.

In Canadian Bank of Commerce v. Wawanesa Mutual Ins. Co., ${ }^{134}$ the insured, while placing insurance on his barn, stated its value to be $\$ 1,500$. The insurance was issued for a face value of $\$ 1,000$ because it was stated in the application that the insurance is "for not exceeding two-thirds of the actual cash value." The insurer contended that the insured had made a false statement as to valuation. This was found to be so, but there was no evidence as to the cost of the barn to the insured or its value at the time of insurance. Martin J., of the Saskatchewan Court of Appeal, as to the effect of over-valuation, commented:135

\footnotetext{
13i Supra, n. 107.

132 Id. at 392.

133 Supra, n. 51.

134 [1925] 1 D.L.R. 72, [1924] 3 W.W.R. 822, 19 Sask. L. R. 149.

135 Id. at 80 .
} 
The policy, however, is not necessarily avoided by the statement of an amount in excess of the real value, inasmuch as matters of value are largely questions of opinion. Where, however, the assured is aware that his statement of value is incorrect, or where the statement is so exaggerated as to make its falsity clear, there is fraud, and the policy is avoided.

Where, however, no question is asked as to the purchase price paid for the property, but the question relating to present actual value is answered correctly, there is no misrepresentation. In Tamson v. Palatine Ins. Co., ${ }^{136}$ the plaintiff's house and contents were insured under a fire insurance policy. Following a claim as a result of fire, the defendant disputed its liability under the policy on the ground that the plaintiff had failed to disclose the price that he had paid for the property, the same being material to the risk. The insured was asked a question in the application for insurance as to "What is the present cash value of the house?", to which he replied " $\$ 2,500$ ". He was not asked about the price paid for the property. Carroll J., of the Nova Scotia Supreme Court, held that under the circumstances of the case, this non-disclosure was not material to the risk. ${ }^{137}$

Where either the purchase price or the present cash value of the property are knowingly over-stated, they will be sufficient for the avoidance of the policy. Fraudulent over-valuation is not necessary since the misrepresentation need only be made "knowingly".

\section{(e) Previous fires}

It has been seen in connection with non-disclosure that insurers regard the question of previous fires as highly material. Where the number or extent of fires is not correctly stated, it may influence the judgement of the underwriter and induce him to enter the contract to his prejudice. Under these circumstances he will be justified in avoiding the policy. Where, however, a small loss by fire occurs in premises other than the insured property, there may not be a misrepresentation.

In Anglo-American Fire Ins. Co. v. Hendry, 138 the defendant had signed an application in blank and requested the agent to fill it in, which he did, in accordance with the answers in another application to a different insurer. The defendant had had a small fire years before, on different premises in another town. The damage was caused by the smoke from the fire and not by actual contact with the flames or heat. The claim was paid by the insurer but the policy was not cancelled. The application in question, as completed by the agent, did not reveal this small fire and the claim therefor. Following a loss by fire, the insurer disputed its liability on the ground of non-disclosure of the previous fire. Judgement was awarded in favour of the insured by the trial court and the Appellate Division of Ontario Supreme Court. The appellant appealed to the Supreme Court of Canada. The Chief Justice, Sir Charles Fitzpatrick, commenting upon the bona fides, remarked:139

$\ldots$ in the answer given to the question as to other fires there was no lack of bona fides, but rather a bona fide mistake as to the nature of the information which the question was intended to solicit. If the incident is open to two constructions the court ought to adopt that construction which is most favourable to the insured.

136 [1928] 2 D.L.R. 867.

${ }^{237}$ Id. at 868 .

138 (1913) 48 S.C.R. 577, 50 C.L.J. 75, 15 D.L.R. 832, affirming 29 O.L.R. 33, 13 D.L.R. 686 (ub. nom. Strong v. Crown Fire Ins. Co.), which aff'd. 10 D.L.R. 42.

130 Id. at 580 . 
It follows from the case that answers to questions in the application form must be substantially true and that if the questions as to previous fires relate to property other than the insured premises, the effect of the answers will be determined by the circumstances of the case, namely the ambiguity of the question asked or the continuance of insurance coverage by the previous insurer following the loss.

The frequency and the date of occurrence of fire and the insurance carried are regarded by the insurance industry as important circumstances material to the underwriters. In Stroschein v. Wawanesa Mutual Ins. Co., ${ }^{140}$ the plaintiff, in answers to questions requiring him to state the number, date of previous fires, and the name of companies that carried the insurance, represented that there had been only one fire with no insurance carried. In fact he had had two fires within four years, the losses from which were covered under policies of fire insurance and he had recovered on both occasions. MacDonald J., of the Alberta Supreme Court, said as to the effect of imperfect representation: ${ }^{141}$

The second fire was an important circumstance and one material to be made known to the insurer in order to enable it to judge of the risk to be undertaken. The imperfect representation made by the applicant amounted to misrepresentation.

Statutory condition 1 of the Alberta Insurance Act, 1942,142 provided:

If any person applying for insurance falsely describes the property to the prejudice of the insurer, or misrepresents or fraudulently omits to communicate any circumstance which is material to be made known to the insurer in order to enable it to judge of the risk to be undertaken, the contract shall be void as to the property in respect of which the misrepresentation or omission is made.

The learned judge, while commenting on the inclusion of the word "fraudulently" in statutory condition 1, observed:143

It is now well settled that the word 'fraudulently' in the foregoing condition connotes actual fraud: Taylor v. London Assur. Corp. [1935] S.C.R. 422 (reversing [1934] O.R. 273). But its application is confined to cases of an omission to communicate. It does not apply to a case of misrepresentation of a material circumstance.

The true representation of the other fire might have resulted in either the outright rejection of the risk, or in the stipulation of higher premiums, and its importance from the insurer's viewpoint is therefore paramount. The practice of the insurance industry, in regarding the fire claims' history of the insured as important, has received manifest judicial recognition and legislative support. ${ }^{144}$

\section{(f) Other cases}

The existence of concurrent insurance on the same property is regarded as a material fact by insurers. Public policy also requires that the temptation to place concurrent insurances exceeding the value of the property be discouraged in order to prevent the insuring public from indulging in acts of arson, putting the life and property of others in danger.

Misrepresentation as to the other insurance held by the insured will inevitably result in the avoidance of later policies which exceed the actual value of the property. In Renshaw v. Ocean Accident \& Guaranteed

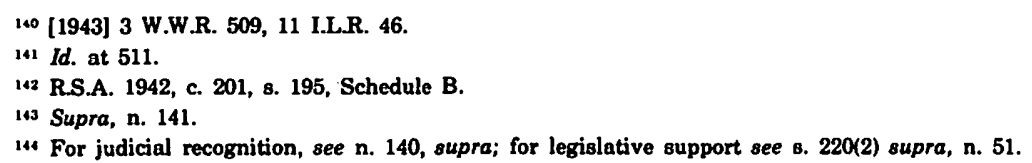


Corp., ${ }^{145}$ the plaintiff, while applying for insurance on the contents of a dwelling house in the sum of $\$ 1,200$, failed to disclose that he had additional concurrent insurance of $\$ 500$ with another company. In fact, before securing the second policy of insurance, the plaintiff had requested the first insurer, "Phoenix", to increase the amount of coverage, but was refused on the ground of the then existing condition of the house. The second policy of $\$ 1,200$ was declared void. Hope J., of the Ontario Supreme Court, in discussing the effect of misrepresentation, stated:146

The earlier policy is effective but in view of the concurrent insurance in the Phoenix, which was existent, the plaintiff should only recover sixty per cent of the value of the insurance on this policy, namely, $\$ 300$.

Insurers are liable only to rateable proportions of loss if there is in force more than one policy of insurance covering the same property and interest. This is now regulated in Alberta by section 225 of the Insurance Act, ${ }^{147}$ which provides:

(1) Where, on the happening of any loss or damage to property insured, there is in force, more than one contract covering the same interest, the insurers under the respective contracts shall each be liable to the insured for its rateable proportion of the loss unless it is otherwise expressly agreed in writing between the insurers.

In the Renshaw case, the insured could recover sixty per cent on the first policy because of the second policy; however, the second policy was declared void because of the misrepresentation in not disclosing the particulars of earlier policy.

Cancellation of policies and refusal of other insurers to insure are circumstances regarded by the underwriters as material as to whether or not the risk will be undertaken. In Bowes v. Fire Ins. Co. of Canada, ${ }^{148}$ the plaintiff applied for fire insurance on a stock of shields and trophies, and represented to the insurers that the policies which he previously held on the property had lapsed or expired, when in fact they had been cancelled for non-payment of the premiums. MacKay J., of the Ontario Supreme Court, made the following findings: ${ }^{149}$

... when the circumstances are such that when insurance has been cancelled for nonpayment of premium, and the insured gets a new policy and later becomes unable to pay his rent, fires are more likely to occur than in premises where things are in order, profits are being made and business is being successfully pursued .... I find that there were misrepresentations which were material to be made known to the insurer in order to enable it to judge of the risk to be undertaken.

If the misrepresentation affects only a small item of the policy, the entire contract of insurance may not be void. It is valid with respect to every other item except the one misrepresented. In Harten v. Grenville Patron Mutual Fire Ins. Co., 150 the plaintiff in answer to a question whether the property or any part thereof was subject to litigation, answered in the negative, which was found to be false but affected only a small item worth $\$ 59.00$. The policy, while void with regard to this item, was valid as to all the others. The application form contained a "basis clause" providing that the answers were regarded as material

its Supra, n. 109.

146 Id. at 185.

147 Supra, n. 51.

148 Supra, n. 55.

149 Id. at 435.

130 Supra, n. 59. 
representations and any untruthful answer or suppression of material facts would result in forfeiture of insurance. The insurer unsuccessfully contended that the whole policy was void. Section 98(1) of the Insurance Act ${ }^{151}$ which set up the statutory condition provided:

The conditions set forth in this section shall be deemed to be part of every contract in force in Ontario ... and ... no variation, omission or addition thereto shall be binding on the insured.

\section{It was held by Green J., of the Ontario Supreme Court, that ${ }^{152}$}

... [s]ec. 98(1) seems to have been enacted for the protection of the insured and ... says in positive language what the contract shall be insofar as the same is governed by statutory conditions ... The section says that the statutory condition shall not be varied.

The statutory condition provides that "the contract shall be void as to any property in relation to which the misrepresentation or omission is material." It was held that the statutory condition should prevail over the clause in the application form for insurance..$^{153}$ Consequently, the insured was able to recover in respect of items not affected by the misrepresentation.

(i) Misrepresentation by assignor

It has been noted that a misrepresentation of material facts in fire insurance renders the contract void and an insured cannot recover under the policy. However, this will not prejudice the claim of an assignee of the policy where the insurance company has assented to the assignment. This is tantamount to a new contract, with the consequence that the defence of misrepresentation available against the original assured cannot be raised against the assignee. This has been made clear in the leading case of. Springfield Fire and Marine Ins. Co. v. Maxim..$^{154}$ In that case, two policies of fire insurance covering a flour mill property were issued by the appellant to the husband of the respondent who, during the currency of the policies, conveyed the property to his wife for value. Nevertheless, the husband of the respondent remained in control of the property even after the transfer to his wife. No formal assignment was executed but the policies were taken to the agent of the company who, on request, transferred the insurance to the name of the respondent. An endorsement was issued in the following terms: ${ }^{155}$

Notice is hereby received and accepted that the property insured under the within policy now stands in the name of Mrs. Millie Maxim, and this policy shall, in future, read and cover in the name of Mrs. Millie Maxim, with loss, if any, payable to the Assured and not as heretofore written. All other terms and conditions remaining unchanged.

The mill property was gutted by fire and the insurer repudiated liability on the ground that the husband of the respondent, i.e., the original assured, in answer to a direct question, had untruthfully stated that he had no previous fires, whereas in fact he had had two fires and on both occasions he had recovered the loss. Rand J., of the Supreme

151 R.S.O. 1927, c. 222. Similar provision exists in other provincial Insurance Acts:supra, n. 70, 8. 208(1); R.S.M. 1970 , c. I-40, 8. $142(1)$; R.S.O. 1970 , c. 224 , в. $122(1)$.

152 Supra, n. 59 at 91.

153 Id.

Is [1946] S.C.R. 604, 13 I.L.R. 108, 4 DLR. 369, affirming [1945] 1 D.L.R. 537, 3 W.W.R. 705, 13 I.L.R. 7, which rev'd. [1945] 4 D.L.R. 115, 3 W.W.R. 209, 12 IL.R. 319

iss Id. at 608 . 
Court of Canada, discussing the assignment of contract of insurance and the effect of insurer's consent thereto, said: ${ }^{156}$

... ordinary assignment is a matter between the assignor and assignee solely; but ... in such insurance it is a conditin that there be assent by the company .... The effect of that assent is, in some form, to substitute the assignee as the person insured in relation to his newly created interest in the subject matter.

Pointing out the difference between the entering into of a new contract and the assignment of an existing contract of insurance, Rand J., observed:157

The only real difference between the taking of a new policy and that of following the procedure of assignment is that the contract with the unearned premium runs for the balance of the old term rather than with a new premium for a new term. With such an alternative at hand, it would be intolerable that the company should be able to raise such a misrepresentation against the assignee.

Kerwin J., also envisaging the difficulties that a substituted insured might encounter if he were bound by the representations of the original assured, commented:158

... the results ... would be serious indeed if, in the ordinary course of business, it were not possible for a purchaser of insured property to enter into a new contract without being bound by all representations that had been made to the insurer by his predecessor in title.

This result is desirable inasmuch as it protects the interest of the assignee who may be innocent and have paid insurance premiums for a number of years. Such an assignee, in the event of fire, would not be at the mercy of any misrepresentation made by his or her predecessor in title. It might be wise to legislate such a result in the provincial Insurance Acts.

(ii) Misrepresentation by mortgagor

If the insured mortgagor is guilty of fraudulent omission or misrepresentation of material facts, it is doubtful whether the interest of the mortgagee, apart from the standard mortgage clause, can be protected under the provisions of the Insurance Act. ${ }^{159}$ Section 222(1) of the Act provides:

Where the loss, if any, under a contract has, with the consent of the insurer, been made payable to a person other than the insured, the insurer shall not cancel or alter the policy to the prejudice of that person without notice to him.

Other provinces have promulgated similar legislation. ${ }^{160}$

This section does not provide that in the event of omission or misrepresentation attributable to the insured, the policy shall not be avoided but only obligates the insurer to serve notice on the loss payee before the insurer can cancel or alter the policy. Under the standard mortgage clause, approved by the Insurance Bureau of Canada and endorsed on the policy, the mortgagee is given a preferred position and his interest is well protected notwithstanding any act, neglect, omission or misrepresentation referrable to the insured mortgagor. This immunity from defences is not based on statutory protection but on contractual provision. The standard mortgage clause provides:

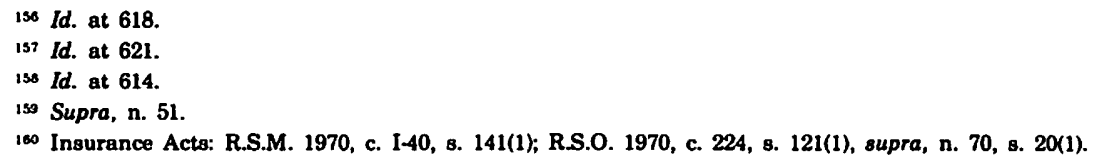


IT IS HEREBY PROVIDED AND AGREED THAT: Breach of condition by mortgagor, owner or occupant, 1. This insurance and every documented renewal thereof-AS TO THE INTEREST OF THE MORTGAGEE ONLY THEREIN-is and shall be in force notwithstanding any act, neglect, omission or misrepresentation attributable to the mortgagor, of the property insured ....

A recent case, decided by the Supreme Court of Ontario, affecting the right of the mortgagees upon the fraudulent omission or misrepresentation of the insured mortgagor is Chenier v. Madill. ${ }^{161}$ In that case, the owners and mortgagees of a hotel brought an action against the insurer to recover a claim under a fire insurance policy following the loss of the property by fire. The mortgage was not paid off but the mortgagees were named in the policy as loss payees "as their interest may appear". The insurer repudiated liability on the ground of fraudulent omission and misrepresentation of material facts, namely the refusal and cancellation of previous insurance and that the property was subject to foreclosure proceedings.

The obligation of proving false representation or fraudulent omission was on the insurer. The insurer failed to establish its defences. The court, however, found that the insured had failed to disclose to the insurer circumstances very material to the risk, namely, that the mortgage was subject to foreclosure proceedings, that final order of sale had been made and that there were arrears of taxes. According to Galligan J., of the Ontario Supreme Court, the real issue was whether the plaintiff knew whether such a fact was material to insurer, and the learned judge made the following observation:162

... in the absence of knowledge [on the part of the insured] of the materiality to the insurer of the circumstances, there can be no fraud in the omission to communicate them ....

The insurer could not establish fraudulent omission or misrepresentation but if it had been successful it appears that the claim of the mortgagees would have been jeopardized.

It has, however, been suggested in the Law Society of Upper Canada Lectures ${ }^{163}$ that the mortgagee, as assignee, is entitled to recover on the assignment free from the defences that might be asserted against the mortgagor if he had brought the action. It is not within the purview of this discussion to present a detailed analysis of the subject. The reader is referred to an informative paper on the position of the mortgagee under the mortgage clause written by Mr. A. C. Heighington, Q.C. ${ }^{164}$

If a mortgagor fails to honor his duty of disclosure there is nothing in the Alberta Insurance Act ${ }^{165}$ which can protect the interest of the mortgagee from the effect of fraudulent omission or misrepresentation. A mortgagee, in such an eventuality, cannot recover from the insurer, although he may have personal remedies against the insured. If the mortgagee is named as loss payee in the policy, or the policy is assigned with the consent of the insurer, the mortgagee cannot recover because a loss payee or assignee is subject to all the defences available against the insured. The consent of the insurer to assignment does not create a novation or make the assignee a party to the contract, but only operates

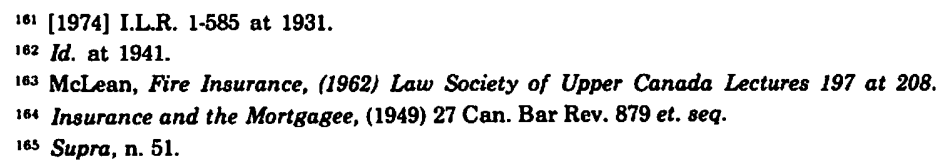


as a recognition of the interest of the mortgagee. It follows, therefore, that in the absence of a standard mortgagee clause protecting the interest of the mortgagee, he is subject to being defeated by any fraudulent omission, misrepresentation or breach of statutory condition before the assignment, unless it can be shown that at the time when consent was given the insurer knew about the acts or defaults of the insured as against the mortgagee who did not know. This calls for suitable amendments to section 222 of the Alberta Insurance Act, which should provide that the interest of a loss payee, who has given value for his interest under a policy, shall not be prejudiced by any act, neglect, omission or misrepresentation attributable to the insured.

\section{B. Life insurance}

\section{Background of statutory provisions}

The statutory regulation of the duty of disclosure in life insurance in the different provinces of Canada has been discussed in chapter one. The present statutory provision dealing with the duty of disclosure in life insurance is contained in section 240 of the Alberta Insurance Act, ${ }^{166}$ which reads:

(1) An applicant for insurance and a person whose life is to be insured shall each disclose to the insurer in the application, on a medical examination, if any, and in any written statements or answers furnished as evidence of insurability, every fact within his knowledge that is material to the insurance and is not so disclosed by the other.

(2) Subject to section 241 , a failure to disclose, or a misrepresentation of, such a fact renders the contract voidable by the insurer.

The Legislatures of other provinces have made corresponding provisions in their Insurance Acts. ${ }^{167}$

The effect of this section is highly unsatisfactory inasmuch as an innocent non-disclosure or misrepresentation of a material fact within the knowledge of the applicant or the insured renders the contract voidable at the instance of the insurer. It seems that such was not the state of affairs between 1926 and 1936. Section 202(2) of the Alberta Insurance Act, $1926,{ }^{168}$ required conscious failure to disclose material facts as a ground for avoiding the policy. That section provided:

Any conscious failure to disclose or any misrepresentation, of a fact material to the contract, on the part of the insured, or the person whose life is insured, shall render the contract voidable at the instance of the insurer.

It is submitted that conscious failure to disclose material facts is not the same thing as innocent non-disclosure. Consciousness implies something more than mere knowledge. There appears to be an element of forethought or premeditation required. For example, if the insured has fainting spells, followed by an electrocardiogram which does not indicate any heart trouble, non-disclosure of these facts may be innocent, the insured in good faith believing that he is in good health. ${ }^{169}$ Conversely, where the insured is specifically told that he suffers from appendicitis and needs an operation, to which he does not submit, and as a result of which he eventually dies, the non-disclosure is conscious. ${ }^{170}$ This will be

\footnotetext{
100 Supra, n. 51.

167 R.S.M. 1970 , c. I-40, s. $160(1)$ \& (2); R.S.O. 1970 , c. 224 , s. 157 , supra, n. 70 s. $123(1)$.

168 S.A. 1926, c. 31.

103 Murphy v. Sun Life Ass. Co. 49 D.L.R. (2) 412, 50 W.W.R. 581, [1965] 1.L.R. I-142, affirming 44 D.L.R. (2d) 369 , 47 W.W.R. 47, [1964] I.L.R. I-124 (Alta. A.D.).

170 Zimmerman v. Nor. Life Ass. Co. [1931] 2 D.L.R. 489, 66 O.L.R. 560.
} 
amply demonstrated from the case law which follows. It is, however, not clear what the intention of the Legislature was in omitting the word "conscious" from the amending section 7 of the Alberta Insurance Act, 1936, ${ }^{171}$ which provided:

(1) The applicant for a contract and the person whose life is to be insured shall each disclose to the insurer in the application for the contract, on the medical examination (if any), or in any statements or answers furnished in lieu of a medical examination every fact within his knowledge which is material to the contract, and a failure to disclose or misrepresentation of any such fact by either person shall render the contract voidable at the instance of the insurer.

Was a higher duty to disclosure intended to be imposed on the applicant and the insured and were there any plausible grounds for this?

It may be interesting to note that there was a double standard for disclosure in 1926 required of the insured and the insurer. Section 202(3) Alberta Insurance Act, 1926,172 required a fraudulent concealment on the part of the insurer. The subsection read:

Any misrepresentation or fraudulent concealment on the part of the insurer of a fact material to the contract shall render the contract voidable at the instance of the insured.

This situation was remedied in 1936 when section 203, omitting the term "fraudulent concealment" and substituting the term "nondisclosure," was passed. Now any misrepresentation or non-disclosure by the insurer will render the contract voidable. No reported case seems to have charged an insurer with non-disclosure or misrepresentation of facts material to the contract. This may be due to the fact that either the insured is not fully aware of his statutory rights or that he has not invoked the law because of his relatively weak financial position. The situation, however, has changed slightly from what occurred prior to 1926. Before this time, a life insurance contract could be avoided even if the insured in good faith misrepresented or did not disclose a material fact which he did not know until the policy was delivered, e.g., a latent disease. ${ }^{173}$ Now only the non-disclosure or misrepresentation of material facts within the knowledge of the applicant and the insured avoids the contract. Nevertheless, the insured still suffers and will continue to suffer until such time as the defence of innocent non-disclosure or misrepresentation is abolished. An effort will be made to make a case for its abolition.

Before discussing the case law, it should be noted that section 240 of the current Alberta Insurance Act ${ }^{174}$ appears to be poorly drafted. If strictly interpreted, it may result in the imposition of an unduly strict duty of disclosure on the applicant and the insured, i.e. disclosure of material facts within their knowledge about which no question is asked in the application. In the absence of fraud, this would be too much to demand from the insured who is not equipped to decide matters of materiality. On the other hand, the insurer, in the light of the experience of the insurance industry, is equipped to know all the material facts necessary for the acceptance of the risk, and therefore should frame questions accordingly. The section in the present form reads:

(1) An applicant for insurance and a person whose life is to be insured shall each dis-

171 S.A. 1936, c. 72.

172 Chapter 31.

173 Jordan v. Provident Institution (1898) 28 S.C.R. 554.

17 R.S.A. 1970, c. 159. 
close to the insurer in the application, on a medical examination, if any, and in any written statements or answers furnished as evidence of insurability, every fact within his knowledge that is material to the insurance and is not so disclosed by the other.

It is submitted that the section in amended form should read:

(1) An applicant for insurance and a person whose life is to be insured shall each disclose to the insurer in answers to direct questions either in the application, on a medical examination, if any, or in any written statements or answers furnished as evidence of insurability, every fact within his knowledge that is material to the insurance and is not so disclosed by the other.

The courts have found, although not consistently, ${ }^{175}$ waiver of information in cases where the insurers have accepted application without requiring the insured to answer all the questions in the application. It is, therefore, obvious that courts may take a similar view where information as to allegedly material facts is not solicited in the application. Nevertheless, it is expedient to amend the section and thereby avoid unnecessary litigation.

\section{Duty of disclosure}

\section{(a) General}

The leading case on the duty of disclosure and its materiality in life insurance in Canada is Mutual Life Ins. Co. of New York v. Ontario Metal Products Co.,176 decided by the Judicial Committee of the Privy Council. The case stands as authority for the test of materiality and the proposition that non-disclosure in the application of the name of a physician who prescribed for or treated the insured for trivial ailments within five years preceding the application, was not, in the circumstances of the case, material and did not afford a defence to the insurer in avoiding the policy. The governing subsection (5) of section 156 of the Ontario Insurance Act, 1914, 177 provided:

No contract of insurance shall contain or have endorsed upon it, or be made subject to, any term, condition, stipulation, warranty or proviso, providing that such contract shall be avoided by reason of any statement in the application therefor, or inducing the entering into of the contract by the corporation, unless such term, condition, stipulation, warranty or proviso is limited to cases in which such statement is material to the contract, and no contract shall be avoided by reason of the inaccuracy of any such statement unless it is material to the contract.

The subsection, in substance, stipulated that no inaccuracy or misrepresentation in the application by the insured shall avoid the policy unless it is material to the contract, notwithstanding the import into the policy of terms otherwise.

Before going into the facts of the case, it should be pointed out that the words "within his knowledge" and the word "conscious", as discussed earlier, were introduced in the Ontario Insurance Act in the revision of $1924,{ }^{178}$ and were not in existence at the time the life policy in the above case was issued.

The insured, in answer to a direct question requiring him to state the name of every physician who prescribed for or treated him during the

\footnotetext{
175 In Alberta and Manitoba an answer penned with a dash has been treated as a negative answer. Hanson y. Queensland Ins. Co. 57 D.L.R. (2d) 131, 66 W.W.R. 215, (Alta. S.C.); Hoey v. Merit Insurance Co. [1971] I.L.R. $1-417$ at 1274 , see note 287 post.

176 [1924] S.C.R. 35, [1924] 1 D.L.R. 127 reversing 54 O.L.R. 299. Aff'd. [1925] A.C. 3 44, [1925] 1 D.L.R. 583, [1925] 1 W.W.R. 362.

177 R.S.O. 1914 , c. 183.

17a Ontario Insurance Act, 1924, c. 50, 8. 119.
} 
past five years, failed to disclose the name of his wife's doctor who had prescribed a tonic for the insured following a complaint of a rundown condition. He was not medically examined by his wife's doctor, but on his request, the doctor assented to the same treatment as for his wife. The policy in question was issued on December 13,1918, and the insured died on April 3,1920, following an operation for intestinal cancer. The plaintiffs, as beneficiaries under the policy, claimed $\$ 50,000$ on the life of Mr. Schuch, the deceased insured. The insurance company denied liability on the ground of non-disclosure as discussed above.

A clause in the policy provided that the application and the policy constituted the entire contract and that the statements by the insured, in the absence of fraud, were to be treated as representations and not warranties. Secondly, the contract also provided that the statements and answers to the medical examiner were true and were offerred to induce the company to issue the policy.

The weight of medical evidence showed that cancer did not exist at the time when insurance was applied for. Moreover, the company's medical examiner, to whom a mistaken answer was given by the insured, deposed that if the fact that the insured was prescribed a tonic was known to him, it would not have affected his acceptance of the risk. The trial judge's finding that the insured had "effected the insurance in good faith" was upheld by the Supreme Court of Canada which also applied the contra proferentem rule. Mignault J., of the latter court, laid down the test of materiality as that of a "reasonable insured", which was rejected by the Judicial Committee of the Privy Council. Their Lordships prescribed the test of a "reasonable insurer". According to Lord Salveson, the test of materiality is: ${ }^{179}$

... a question of fact in each case whether, if the facts concealed or misrepresented had been truly disclosed, they would, on a fair consideration of the evidence, have influenced a reasonable insurer to decline the risk or to have stipulated for a higher premium.

The Judicial Committee of the Privy Council, despite the good faith of the insured, found that answer to question 18, dealing with the disclosure of physician's name, was inaccurate ${ }^{180}$ but subsection 156(5) of the Ontario Insurance Act, 1941,181 worked to the benefit of the beneficiary because the inaccuracy was not material. The results achieved in this case would have been the same as reached in the English case of Dawson, Ltd. v. Bonnin ${ }^{182}$ but for the above section. In that case, an inaccurate answer which was not material avoided the contract because the accuracy of the answer was the basis of the contract.

It follows, therefore, that any inaccuracy in the statements which will avoid a contract must be material as judged by a reasonable insurer. If a finding could then be reached that the misrepresentation was material, the good faith or innocence of the insured and the lack of knowledge about the latent disease would have been of no consequence. Conversely, if the policy was issued after the statutory revision of 1924 as referred to earlier, it could not be avoided despite material misrepresentation of the insured because the evidence of cancer was not within his knowledge

\footnotetext{
${ }^{779}$ Supra, n. 176, [1925] A.C. 344 at $351-52$

180 Id. at 366.

181 Supra, n. 177.

102 [1922] 2 A.C. 413, 91 LJ.P.C. 210.
} 
and there was no "conscious" failure to disclose the supposedly material fact.

The amended provision reads: ${ }^{183}$

119-(1) The insured and the person whose life is insured shall each disclose to the in. surer every fact within his knowledge which is material to the contract.

(2) Any conscious failure to disclose, or any misrepresentation of, a fact material to the contract, on the part of the insured or the person whose life is insured, shall render the contract voidable at the instance of the insurer.

The revised provisions are therefore to be preferred. The position under the present enactment will later be compared with the revisions of 1924 in Ontario and of 1926 in Alberta. The cases decided after these revisions may now be looked at briefly.

In Turner v. B.C. Mutual Benefits Association, ${ }^{184}$ the insured was not subjected to medical examination by the Association. In an answer to a direct question: "Have you been treated by a physician during the last three years?" the insured replied in the negative. In fact she had been treated by a physician for a cold or a touch of influenza; the physician prescribed a tonic for her own run-down condition. The insured died eleven months after the issuance of the policy due to shock following two abdominal operations to remove a tumor in the uterus which, according to the operating surgeon, had existed for six months.

The insurer denied liability on grounds of misrepresentation. Section 83(1) of the British Columbia Insurance Act, $1925,{ }^{185}$ provided:

No contract shall be rendered void or voidable by reason of any misrepresentation, or any failure to disclose on the part of the insured or the person whose life is insured, in the application for the insurance or on the medical examination or otherwise, unless the misrepresentation or failure to disclose is material to the contract.

Section 83(2) of the Act stipulated for conscious failure to disclose material facts. That subsection read:

Any conscious failure to disclose, or any misrepresentation of, a fact material to the contract, on the part of the insured or the person whose life is insured, shall render the contract voidable at the instance of the insurer.

The special jury found that the words "treated by a physician" as contained in the application, were not intended to include trivial ailments like "a touch of influenza or a cold", and that the misrepresentation was not material. ${ }^{186}$ McPhillips J.A., of the British Columbia Court of Appeal, commenting upon the practice of the insurer to refrain from calling for a medical examination when the applicant revealed no medical treatment, said: ${ }^{187}$

... [the insurer] having failed to take a reasonable and proper business precaution [medical examination of the insured] seeks to deny its contract, ... upon some inadvertent answers, in the application.

As to the materiality of misrepresentation, the learned judge remarked: ${ }^{188}$

... it may be rightly assumed that the jury was of the opinion that no misrepresenta-

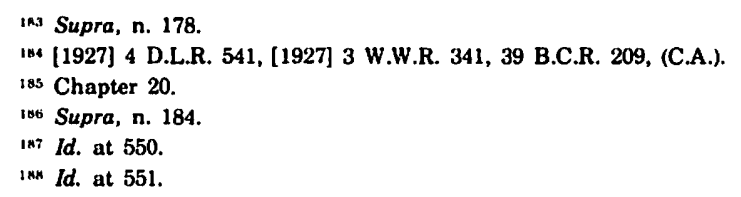


tion or failure to disclose occurred,-or, even if of a contrary view, that nevertheless the misrepresentation or failure to disclose was not material to the contract.

The leading case of Mutual Life Ins. Co. v. Ontario Metal Products, ${ }^{189}$ was applied. Both these cases show that failure to disclose treatment by a physician for trivial ailments does not constitute misrepresentation of material facts. If it could be argued that the misrepresentation was material, it was nevertheless not within the knowledge of the insured and there was no conscious failure to disclose them.

Where the insured is specifically told about a serious disease necessitating an operation to which he does not submit, and he dies as a result thereof, failure to disclose such a disease is conscious and will avoid the policy. In Zimmerman v. Northern Life Ass. Co., ${ }^{190}$ an Ontario case, the insured was issued two policies of life insurance, one before he was told about the disease and the other afterwards. The policies were issued as a result of the solicitation of an insurance agent who paid the premium and took a pro-note from the insured. The insured was diagnosed as suffering from appendicitis and was told about this and an operation was recommended. The insured failed to get the operation and died as a result of a diseased appendix. The conscious failure to disclose the disease avoided the second policy but the plaintiff was able to recover under the first policy.

Section 125(1) of the Ontario Insurance Act, 1927,191 required the insured to "disclose to the insurer every fact within his knowledge which is material to the contract" and subsection (2) rendered the contract voidable for any "conscious failure to disclose, or any misrepresentation of a fact material to the contract."

Raney J., of the Ontario Supreme Court, as to the effect of the word "conscious", said:192

... though the word 'conscious' is introduced in s. 125(2) of the present revised statute, before the words 'failure to disclose' it is not introduced before the word 'misrepresentation' which immediately follows ... s.s.(2) should be read as though its language were,

'any misrepresentation of a fact within his knowledge and material to the contract'.

The old rule which prevailed prior to the revisions of 1924 and 1926 and which provided for avoidance of the policy for innocent misrepresentation of material facts not within the knowledge of the insured has been changed by the revised statute. The revised provision in Alberta ${ }^{193}$ provided:

202-(1) The insured and the person whose life is insured shall each disclose to the insurer every fact within his knowledge which is material to the contract.

(2) Any conscious failure to disclose, or any misrepresentation of, a fact material to contract, on the part of the insured or the person whose life is insured, shall render the contract voidable at the instance of the insurer.

Under the present enactment, the insurer can dispute liability under the contract for misrepresentation and non-disclosure as to material facts within the knowledge of the applicant and the insured. It need not establish conscious failure to disclose material facts. The comment by the Editor of Canadian Abridgement ${ }^{194}$ in that regard is worthy of note:

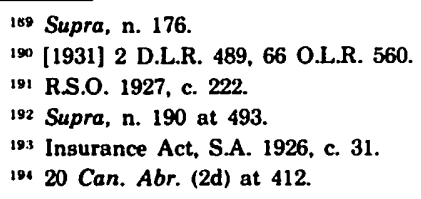


The Insurance Act, R.S.O. 1960, c. 190 was amended by 1961-62, c. 63, s. 4 subsequent to Zimmerman v. Nor. Life Assur. Co., supra. S. 149, as amended provides for a duty on both the applicant and the life insured to disclose 'every fact within his knowledge that is material to the insurance and is not so disclosed by the other.' The section by subs. (2) provides that a failure of compliance renders the contract voidable. The provision which governed at the time Zimmerman arose provided for 'conscious' failure of compliance. Perhaps this change leaves open the question whether there is a middle position between deliberate misrepresentation and innocent misrepresentation as to matters not within the applicant's knowledge-i.e., an innocent misrepresentation as to something within his knowledge.

Murphy v. Sun Life Ass. Co., ${ }^{195}$ decided by the Appellate Division of the Supreme Court of Alberta in 1965, suggests that there could be innocent misrepresentation of facts within the knowledge of the insured. This will be discussed later under the title "Applicant's Health".

Where the insured has suffered from a disease known to him, which was cured before the application was made, but he failed to disclose the same in answer to direct questions, the policy has been avoided. In McArthur v. Prudential Ins. Co., ${ }^{196}$ the insured died of coronary thrombosis. In reply to specific questions the deceased had stated that he did not receive any treatment for heart failure, chest pains, high blood pressure, nor for sugar in the urine or diabetes. Shortly before the policy was issued, electrocardiograms of the insured's heart were taken which did not indicate any heart disease. The urine analysis, however, showed traces of sugar. The deceased was informed that he suffered from a mild case of diabetes and was placed on a special diet. A test conducted later showed that there were no symptoms of diabetes and the insured did not die of this disease. The name of insured's physician appeared on the application form but the insurer did not take the initiative of conducting an inquiry. The insurer repudiated liability on the ground of nondisclosure of diabetes and contended that the misrepresentations were material and induced the company to enter into the contract.

Ferguson J., of the Ontario Supreme Court, required the insured to know about the materiality of the facts undisclosed. He said:197

...he [the insured] must be taken to know these matters were material as the questions on the form concerned them and his signature must be taken to be corroboration.

The opinion of Ritchie J., of the Supreme Court of Canada, in Henwood v. Prudential Ins. Co., ${ }^{198}$ appears to be to the contrary effect. He says: ${ }^{199}$

It must, of cource, be recognised that a misrepresentation is not necessarily 'material to the insurance' simply because it has been elicited in answer to a question devised by the insurance company but in a case where senior officials of the company testify that untrue answers given by an insured would have effected the rate and the risk, there is, in my opinion, evidence that these answers bore a direct relation to the acceptance of the risk by the insurer.

In the Henwood case, the insured had failed to disclose in the written application and on medical examination that she had consulted and been treated by a psychiatrist for nervous disorders. She was later killed in a car accident while travelling as a passenger. The circumstances of

12549 D.L.R. (2d) 412, 50 W.W.R. 581, [1965] I.L.R. 1-142, affirming 44 D.L.R. (2d) 369, 47 W.W.R. 47, [1964] 1.L.R. $1-124$ (Alta. A.D.).

1966 D.L.R. (3d) 477. [1969]2 O.R. 689, [1969] I.L.R. 1-279 at 730.

197 Id. at 734 .

198 [1967] S.C.R. 720, 64 D.L.R. (2d) 715, affirming [1965] I.L.R. 1.514.

190 Id. at 726. 
the death were not in any way connected with the non-disclosure or misrepresentation of facts which, according to Ritchie $J$., had influenced the judgement of the insurer in accepting the risk.

In the McArthur200 case the diagnosis of diabetes was held to be material, whether the view of the deceased as to the existence of the disease was accurate or not, and regardless of the position whether the insured's physician's opinion was right or wrong. The defendant's opinion as to materiality was accepted by the Ontario Supreme Court, citing Henwood case as authority. This case will be discussed later under the heading "Burden of Proof". In the McArthur case Ferguson J., made the following remarks: ${ }^{201}$

... the defendant's evidence that the matters undisclosed were material to the risk and at the best would have effected the premium payable must be accepted as the attitude of a reasonable underwriter.

The court, in accepting the evidence of the defendant as that of a "reasonable underwriter", was guided by the Henwood case which, in effect, decided that where no evidence was adduced to show the unreasonableness of the practice of the insurer, there was no burden on the insurer to prove that his practice was reasonable.202 This implies that the burden of proving unreasonable practice is shifted to the plaintiff. This is a very heavy onus for the plaintiff to discharge. He may not be in a position to engage insurance expertise to discharge the burden, and he is incapable of doing so himself. If insurers were required to prove reasonable practice, it would not be very difficult to do so, in view of the experience of the insurance industry available to them. It is suggested that even in cases where the individual insurer establishes that its practice was not inconsistent with other companies, the courts should examine whether the practice by the insurance industry is a healthy one. Should an unsound practice arise in the industry, the courts could exercise a healthy influence in deciding against it.

\section{(b) Non-disclosure and/or misrepresentation attributable to insurer's medical officer}

If the omission or misrepresentation is referrable to the fault of the company's medical examiner, the insured or his beneficiary cannot be bound by it, and the insurer must suffer the consequences. This is just and reasonable because the insured is in no way responsible for such act or omission.

In Pearce v. National Life Ass. Co.,203 an old Ontario case, the medical officer of the company, who was also the insured's physician, after his examination, classified the insured as a "first class risk", but failed to write an answer to a question because the wrong space was filled in, and there was not enough room in the previous space to fill in the whole answer. The defendant, knowing this, and without any attempt to have the omission supplied, accepted the risk. The insurer pleaded that the insured was in bad health at the time of application for insurance and had made misrepresentations to the medical officer of the company.

Meredith J.A., of the Ontario Court of Appeal, found that there was

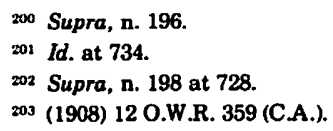


no evasion, concealment or misrepresentation on the part of the insured and the omission was due to the carelessness of the medical officer in filling out the application. As to the ex post facto plea of the insurer and the effect of omission, the learned judge observed:204

It is very easy to be suspicious, and to be wise, after the events ... have happened... I cannot understand how the insured could be bound by any errors made... which was entirely the work of the defendant's medical officer, and over which the applicant had no control, and of the contents of which probably he ought not to have any knowledge.

The case was decided correctly and on just and reasonable grounds as the medical officer was the representative of the insurance company, and was working for and in the interest of the latter. If this principle could be extended to the cases where non-disclosure or misrepresentation results due to the fault of the insurance agent, the problems of the insured public might be alleviated to a greater extent.

In a recent Quebec case of Lacroix v. L'Industrielle Compagnie d'Assurance Sur la Vie, ${ }^{205}$ the company's medical officer, who was also the regular doctor of the insured, for unexplained reasons, did not carry out the medical examination until three months after the completion of the medical report by him. In the report he filled in the answer "No" to a question asking about high blood pressure. There was no evidence that the insured knew about the blood pressure or the treatment therefor. He died of coronary thrombosis and the defendant contended non-disclosure of consultation for abnormal blood pressure. Challies J., of the Superior Court, District of Montreal, as to the misrepresentation and the responsibility therefor, said:206

... you cannot misrepresent or conceal a fact that is not within your knowledge... Moreover, as the medical examiner was the representative of the defendant and knew better than anyone the blood pressure of the insured and as he inserted the answer 'No' to the question whether he had ever suffered from high blood pressure, the responsibility for his error, if error there was, must be borne by the defendant and not by the insured.

This result appears consistent with a somewhat more enlightened approach to the insured's duty of disclosure taken by Quebec courts in general. This point will be discussed further in the section on disclosure through insurance agents.

(c) Applicant's health

Where the insured makes non-disclosure or misrepresentation of facts material to the contract that are within his knowledge, it does not matter whether they are deliberate or innocent: the insured in both cases is treated by the Legislatures equally, ${ }^{207}$ i.e., the contract is voidable in these instances and no refund of premium may be allowed in either situation.

(i) Deliberate non-disclosure or misrepresentation

In Vanini v. Prudential Ins. Co., ${ }^{208}$ the risk was accepted without a medical examination. The insured, in reply to a direct question, misrepresented his hospitalization in a sanitarium for tuberculosis and possibly silicosis. The insured remained in the hospital for six weeks

204 Id. at $360-61$.

200 [1970] I.L.R. 1.314 at 875 .

200 Id. at 876 .

207 Insurance Acts: R.S.M. 1970, c. I-40, s. 160(1) \& (2); R.S.O. 1970, c. 224, s. 157, supra, n. 70, 8. 123(1).

${ }^{200}$ [1945] 3 D.L.R. 492, [1945] O.W.N. 500, 12 I.L.R. 162. 
spitting blood, but he was later discharged as not tubercular. He died of coronary thrombosis within one month of the application for insurance. The insurer denied liability for misrepresentation.

Roach J.A., of the Ontario Court of Appeal, found that the insured had failed to disclose circumstances which were within his knowledge and material to the acceptance of the risk. The learned judge adopted "the language of the Master of the Rolls"209 in London Assurance v. Mansel, referred to by Masten J.A., in Selick v. New York Life Insurance Co. ${ }^{210}$

No human being acquainted with the practice of companies or of insurance societies or underwriters could doubt for a moment that the answers complained of relate to facts of great materiality.

There was deliberate misrepresentation of material facts and the policy was rightly avoided.

(ii) Innocent misrepresentation

In Murphy v. Sun Life Ass. Co., ${ }^{211}$ decided by the Alberta Supreme Court Appellate Division, the insured had a fainting spell. However, a physical examination and two electrocardiograms revealed that he was in normal health. One month thereafter the agent of the insurance company approached him for life insurance coverage. The deceased applied for a policy and signed the portion of the application completed by the defendant's medical examiner. The application contained the following specific questions about loss of consciousness, physical examination or treatment by physicians and electrocardiograms:

Q. 4.- Have you ever suffered from or consulted a physician or other practitioner for any complaint or affection:

a. Of the brain or nervous system?

(for example-fits, nervous breakdown, loss of consciousness. ...)

A. No.

Q. 8.-A. Have you, during the past five years, been examined or treated by, or consulted a physician or other practitioner ... ? Give details.

A. Yes. May 1960, personal routine annual medical. Dr. G. Hardy, Calgary. No pathology, no treatment, found physically fit.

c. Have you ever submitted to electrocardiographic, . . . tests? If so what tests, why, when and the results?

A. No.

The insured died of natural causes but the defendant repudiated the claim of the beneficiary on the above grounds. The company's doctor who had examined the insured had also died. The application form was the prima facie proof of the facts in question but the burden of proof that the facts were either not within his knowledge or were not material had shifted from the defendant to the plaintiff. The declaration signed by the insured provided that answers to the questions in the application form made to the medical examiner were read by him and certified to be full and true.

Smith C.J.A., of the Alberta Supreme Court Appellate Division, concurred with the opinion of the trial judge that there had been failure to disclose material facts within the knowledge of the deceased insured,212

\footnotetext{
200 Supra, n. 208 at 156.

21048 D.L.R. 416 at 427.

211 Supra, n. 175.

212 Id. at 713.
} 
within the meaning of section 226 Alberta Insurance Act, 1955, 213 now section 240 of the Act, ${ }^{214}$ which provides:

(1) An applicant for insurance and a person whose life is to be insured shall each disclose to the insurer in the application, on a medical examination, if any, and in any written statements or answers furnished as evidence of insurability, every fact within his knowledge that is material to the insurance and is not disclosed by the other.

(2) Subject to section 241 , a failure to disclose or misrepresentation of, such a fact renders the contract voidable by the insurer.

Accepting the evidence of the defendant's actuary the Chief Justice said:215

...the evidence of Gower was admissible as evidence tending to show that a reasonable insurer would have declined the risk or stipulated for a higher premium, had there been proper disclosure....

The judgement of McDermid J., of the Alberta Supreme Court, is worthy of attention. As to the innocent non-disclosure, the judge admitted that the insured was an honest man and was told by four doctors that he was in perfect health. The judge speculated that this could be the reason why the questions were not answered, but said that the insured as a "reasonable man" should have made the full disclosures. Citing Jordan v. Provincial Provident Institution, ${ }^{216}$ a nineteenth century case, as authority, he observed:217

It matters not that the non-disclosure and misrepresentation were innocent and there was no intention to defraud.

It is noteworthy that the Jordan case arose in 1898 when life insurance contracts could be avoided for non-disclosure of latent diseases not within the knowledge of the insured. Moreover, the Jordan case was distinguished in Zimmerman v. Nor. Life Ass. Co. ${ }^{218}$ and doubt was cast on its authority in the case of Arnprior v. U.S. Fidelity \& Guaranty Co., ${ }^{219}$ both by Meredith, C.J.O., in the Ontario Court of Appeal and by Anglin J., in the Supreme Court of Canada.220

Commenting upon the materiality and the absence of relation of the facts omitted to the circumstances of the death, McDermid J., of the Alberta Supreme Court, in the Murphy case also said:221

The fact that the deceased might have considered that the answers were not material does not excuse him ... In my opinion it does not matter what the cause of the death was. If the deceased had died in a car accident or from a heart attack it does not effect the outcome of the law suit.

(iii) Critique of the Murphy decision

In this case the insured believed in good faith that he was in perfect health. This belief was reinforced by the fact that four doctors had made statements to that effect. However, if there can be a difference of opinion among medical experts as to the outcome of electrocardiograms, the layman insured should not be expected to know this. There was no in-

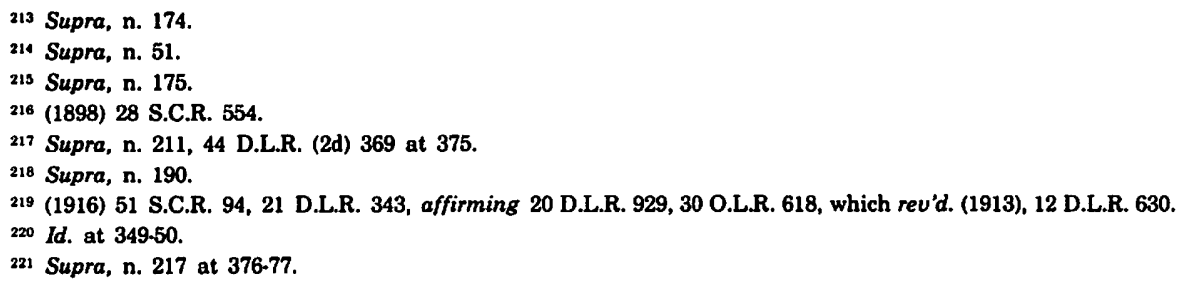


dication in the proposal form to suggest to the layman insured that where the physical examination, x-rays, electrocardiograms, clinical tests, etc., do not reveal any disease or symptoms of disease or where the insured volunteers himself to a normal check-up, there is nevertheless a duty to disclose such examinations. It is easier for the insurers in the light of their experience, to frame questions to that effect and to emphasize to the insuring public the importance which they attach to these tests.

It seems to be the height of injustice that an insured who deliberately conceals or misrepresents material facts should suffer the same consequences as an innocent insured who makes representations honestly and in good faith. Yet both types of insured have been subjected to repudiation of contract with no return of premiums.

It is strongly urged that, subject to the discussion which follows, the defence of innocent non-disclosure or misrepresentation should be abolished, the claim of the plaintiff in such cases should be allowed, and the argument of the insurer that a higher rate of premium would have been charged should not be allowed to vitiate a claim.

Whenever the risk is greater than stated, a higher premium should be charged, or the amount representing the difference between the actual premium chargeable and the premium received with interest thereon from the date of issue of policy until the date of death or maturity should be deductible from the policy proceeds. A life policy becomes incontestible after two years under section 241 of the Alberta Insurance Act ${ }^{22}$ which provides:

(1) This section does not apply to a misstatement of age or to disability insurance.

(2) Subject to subsection (3) [dealing with group insurance] where a contract has been in effect for two years during the life time of the person whose life is insured, a failure to disclose, or a misrepresentation of, a fact required to be disclosed by section 240 does not, in the absence of fraud, render the contract voidable.

This suggestion is based upon the legislative protection already extended to the insured in the above section. In essence it provides that in the absence of fraud, a failure to disclose or a misrepresentation of material facts does not render the contract voidable if the contract has been in effect for two years.

Under present law, if the insured, who is guilty of non-disclosure or misrepresentation, dies one day short of two years, the claim of the beneficiary is prejudiced, but if he dies any time after the said period, the beneficiary's interest is fully protected, unless the insurer can prove fraud on the part of the insured. Why should beneficiaries under the two situations be differently treated when the insured in both cases is guilty of non-disclosure or misrepresentation and the beneficiaries are equally innocent?

Except in cases of fraud, where the facts withheld or misrepresented would have resulted in a higher premium if properly disclosed and the insured dies within two years, it is suggested that a differential premium be charged for the full two years and that the contract be made incontestible in respect of a claim by the beneficiary. This would bring to an end any inequality between the position of innocent beneficiaries according to whether the policy has been in effect for less or more than two years.

${ }^{222}$ Supra, n. 51. Similar provision exists in other provincial Insurance Acts: Supra, n. 70, 8. 123(2); R.S.M. 1970, c. I-40, s. $161(2)$; R.S.O. 1970 , c. 224 , 8. $158(2)$. 
Except for fraud, the insurer would perhaps be left with only one complete defence, namely, that it would not have accepted the risk if the material facts had been truthfully disclosed. This defence is reasonable in circumstances where the insurer can establish by industry practice that such risk is totally unacceptable. To meet these situations the courts should be prepared to determine whether the facts withheld or misrepresented are serious enough to entirely preclude acceptance of the risk.

(iv) Change in insurability and incontestibility

Sections 237 and 241 of the Alberta Insurance Act ${ }^{223}$ respectively provide for the coming into effect of life insurance contracts and the incontestibility of the contract after two years. The sections read:

237. (1) Subject to any provision to the contrary in the application or the policy, a contract does not take effect unless

(a) the policy is delivered to an insured, his assign or agent, or to a beneficiary,

(b) payment of the first premium is made to the insurer or its authorized agent, and

(c) no change has taken place in the insurability of the life to be insured between the time the application was completed and the time the policy was delivered.

(2) Where a policy is issued on the terms applied for and is delivered to an agent of the insurer for unconditional delivery to a person referred to in subsection (1), clause (a), it shall be deemed, but not to the prejudice of the insured, to have been delivered to the insured.

241. (1) This section does not apply to a misstatement of age or to disability insurance.

(2) ... where a contract has been in effect for two years during the lifetime of the person whose life is insured, a failure to disclose, or a misrepresentation of, a fact required to be disclosed by section 240 does not, in the absence of fraud, render the contract voidable.

Section 237(1)(c) governs the eventuality of some serious disease intervening between the time the application is completed and the time the policy is delivered. The contract does not take effect in such a situation. The section is silent as to what would be the position where the insured notifies the change taking place before the delivery of the policy but the insurer does not require a de novo application and a fresh medical examination prior to delivery of the policy. It seems that in such a situation, the insurer would be estopped from denying liability because of its conduct towards the insured. This should be specifically provided for in the section.

In Desser v. Occidental Life Ins. Co. of California, ${ }^{224}$ the insured was issued two policies of life insurance by the defendant. The first policy was issued three years prior to, and the second policy a day after, the death of the insured. The insured had, to his knowledge, suffered heart disease for the past five years but denied the same in answer to a question in the proposal form. Application for the second policy was made on March 11, 1967. On March 31, 1967, the insured's doctor, in order to frighten him into the hospital, emphatically told him that he had severe heart disease, but he refused hospitalization. The insured died of coronary arteriosclerotic heart disease on April 4, 1967, and the policy was

${ }^{223}$ Supra, n. 51. Provisions similar to section 237 are to be found in other provincial Insurance Acts: Supra, n. 70 , 8. $128(1)$; R.S.M. 1970, c. I-40, 8. 157(1); R.S.O. 1970, c. 224, s. 154(1). For provisions corresponding to s. 241 , see n. 222, supra.

224 [1969] I.L.R. 1-290 at 783 (Man. Q.B.). 
mailed to his address on April 5. The first policy had become incontestible and the claim was therefore paid. The insurer denied liability on the second policy on account of misrepresentation of heart disease and change in the insurability of his life after the second application but before the delivery of the policy. Tritschler C.J., of the Manitoba Queen's Bench, found that the answer given to the relevant question was knowingly false and the proof thereof was "well beyond a mere balance or preponderance of probabilities." 225 Dismissing the action of the plaintiff, he made the following comments:226

If the contract of insurance was not voidable it is clear beyond any doubt that a grievous change took place in the insurability of Oscar Desser's [the insured's] life between March 11, 1967 and the time the policy was delivered.

In spite of the fact that the insured had knowingly failed to disclose heart disease in his application for the first policy, the insurer did not charge fraud and contest the policy.

(v) Good health

The insured in Canada is not now required to state opinions about his health, and is only asked to list diseases that are within his knowledge and material to the risk. ${ }^{227}$ At a time when the insured was asked to state his opinion regarding his health, such questions concerning "good or sound health" were treated liberally by the courts. Two Quebec cases decided in the early twentieth century will be discussed to show the state of the law at that particular time.

In Fernand v. Metropolitan Life Ins. Co., ${ }^{228}$ a policy was issued on the life of a 15-year old girl who, prior to the application for insurance, had undergone an operation on her throat, the nature of which was not known to her. She failed to disclose that she suffered from goitre. Questions to be asked by the Medical "Inspector" were completed in his writing but were not signed by the insured. The insured died ten months after the issue of the policy following a second operation for goitre. The insurer repudiated liability on account of misrepresentation. Archibald J., of the Quebec Supreme Court, found that at the time of the contract, there was no evidence of the existence of goitre in the insured and that the answers as written were the answers of the insured. The policy could not therefore be avoided for misrepresentation. As to the meaning of "sound health", the learned judge made the following observation:229

... the expression 'sound health', is a relative expression. No person is in sound health; otherwise he would live forever. I think the words are to be interpreted in the sense of absence of any disease actually at the time operating in a manner likely to seriously threaten the individual's life ... I do not think that the proof discloses with any degree of certainty, that at the time of the contract of insurance, the disease from which the insured afterwards died was in any state of activity, or that the insured was, at the time, suffering from that disease in such a sense that she could not be described to be in good health.

In Security Life Ins. Co. v. Power, 230 the insured, in answer to a question whether he was suffering from gout or rheumatism, replied "some rheumatism years ago," since after consultation with his medical ad-

225 Id. at 786 .

226 Id. at 787.

227 Insurance Acts Supra, n. 51, s. 240; supra, n. 70, 8. 123; R.S.M. 1970, c. I-40, 8. 160; R.S.O. 1970 , c. 224 , 8. 157.

228 (1913) 44 Que. S.C. 117, aff'd. 47 Que. S.C. 520 (C.A.).

229 Id. at $120-21$.

230 (1915) 24 Que. K.B. 181 (C.A.). 
viser he had doubts about the disease. The insured died of gout and the appellant contended that the insured had failed to disclose the truth concerning his condition. The jury returned a verdict that the answers of the deceased were true and sincere. This finding was not disturbed by the Court of Queen's Bench in Appeal. Carroll J., of this court, stated the following about the implication of the term "good health":231

In the absence of fraud, a statement that an applicant for insurance is in good health should be interpreted liberally, and not as meaning that he is entirely free from infirmity or disease. Although the fact that an applicant is suffering from gout is material to the risk to be undertaken, yet if the evidence gives reason to think that at the time of the application the gout was inactive, and its existence was unknown to the applicant, the jury will be justified in finding that the answers to questions were frank and complete, although there was no disclosure of the gout.

In the absence of such liberal interpretation of the term "good health" or "sound health", the insurer could find it easier to avoid payment of claims on one ground or the other and retain the premiums.

\section{(d) Applicant's age}

Section 243 of the Alberta Insurance Act, 232 dealing with misstatement of age provides:

243. (1) This section does not apply to a contract of group insurance or of creditor's group insurance.

(2) Subject to subsection (3), where the age of a person whose life is insured is misstated to the insurer, the insurance money provided by the contract shall be increased or decreased to the amount that would have been provided for the same premium at the correct age.

(3) Where a contract limits the insurable age, and the correct age of the person whose life is insured at the date of the application exceeds the age so limited, the contract is, during the lifetime of that person but not later than five years from the date the contract takes effect, voidable by the insurer within 60 days after it discovers the error.

Similar provision exists in other provincial Insurance Acts. ${ }^{233}$

The misstatement of age is no longer regarded as essential from an underwriting point of view but is important for actuarial calculations. ${ }^{234}$ The insurer cannot, therefore, claim relief on the ground of misrepresentation of age. Erroneous statement of age can only result in reduction or increase of sums payable on death or maturity. The rule is not applicable in contracts of group insurance and in cases where the applicant's age exceeds the maximum insurable age.

In Standard Trusts Co. v. Can. Life Ass. Co. ${ }^{235}$ when proof of death was filed, it transpired that the insured had misstated his age, the correct disclosure of which would have warranted a higher premium. The policy was for $\$ 50,000$ and consequently the sum insured was reduced to $\$ 47,500$ but the claim was allowed.

The interest of an insured is protected in case of misstatement of age, whether intentional or unintentional.

(e) Other cases

(i) Refusal of insurance by other companies

23120 Can. Abr. (2d) 2524 at 415.

232 Supra, n. 51.

${ }^{233}$ R.S.M. 1970, c. I-40, s. 163; R.S.O. 1970, c. 224, s. 160 ; supra, n. 70, s. 126.

234 Editor's note, $20 \mathrm{Can}$. Abr. (2nd) 417.

${ }^{235} 51$ D.L.R. 275, [1920] 1 W.W.R. 516, 15 Alta. L.R. 546, reversing in part 48 D.L.R. 685, [1919] 3 W.W.R. 387, (C.A.). Abridged, 17 Can. Abr. (2nd) 417. 
The refusal by insurance companies to insure the life of an applicant is regarded as a material fact by the underwriters. If the applicant fails to so disclose, the insurers may endeavour to avoid the policy. It is submitted that refusal by other insurance companies to insure the applicant's life should only be regarded as material when the rejection of the risk was based on legitimate underwriting considerations. If the insurer refuses merely on the ground that it already holds a number of policies on the life of the insured, who is declared by Medical Examiners of the insurers as a "first class life", as was the position in the English case of London Assurance v. Mansel, 236 the refusal should not be treated as a rejection of the risk and should not be regarded as material.

In Compagnie D'Assurance "La Sauvegarde" v. Sacker, 237 a Nova Scotia case, the applicant failed to disclose that he had applied for insurance to, and been refused by, three companies. The policy contained a clause that in the absence of fraud, statements by the insured were to be treated as representations and not warranties. The insured was refused insurance four times but told the Medical Examiner of the Company that he was only refused once. This constituted a diminution of the appreciation of the risk and the policy was avoided for false declaration. It was not made clear what were the circumstances which led to the rejection of the four applications.

The application can only be considered as having been rejected if it was acted upon. Where the application was not considered by the insurance company at all, there can be no rejection. In Kiernan v. Metropolitan Life Ins. Co., ${ }^{238}$ decided by the Supreme Court of Canada, the applicant was asked to state whether he had ever applied for insurance without ever receiving it, to which he answered in the negative. In fact, the insured, a physician, had earlier applied to one insurance company at a time when he was suffering from hoarseness. The company's Medical Examiner, a personal friend of the applicant, told him not to appear for examination until the condition had vanished. No further action was taken on the application. In a proposal form to another insurance company, the insured denied rejection. The insured later died of throat cancer and the insurer denied liability. The majority of the Supreme Court did not discuss the issue of rejection of the earlier application but found that the contract was voidable on other grounds. Mignault and Rinfret JJ., in their dissenting judgements, expressed the view that the failure on the part of the insured to disclose the earlier negotiations did not constitute a misrepresentation. ${ }^{239}$

The dissenting opinion concerning the earlier negotiations appears to be reasonable inasmuch as there was no consideration of the application from the underwriting or actuarial point of view and the insurer cannot be said to have been prejudiced thereby. In cases where there has been rejection but the life can still be accepted as a risk with a higher rate of premium, any non-disclosure or misrepresentation of any earlier rejection should not be allowed to affect a claim under the policy. Instead, the difference between the two rates of premium, as discussed earlier, should be deducted from the sum payable.

236 (1879) 41 L.T. 225.

237 (1923) 29 R.L.N.S. 314

238 [1925] S.C.R. 600, [1925] 4 D.L.R. 439.

239 Id. 
Apart from the above facts, family medical history is also considered as an important circumstance, especially in cases where the insured dies of hereditary disease. ${ }^{240}$

(ii) burden of proof

The onus of proving non-disclosure or misrepresentation and its materiality is on the insurer. In life insurance, the insurer must establish that the facts omitted or misrepresented were within the knowledge of the applicant or insured and were material to the acceptance of the risk. Materiality is a question of fact in each case. The test of materiality was laid down by Lord Salveson of the Judicial Committee of the Privy Council in the leading case of Mutual Life Ins. Co. v. Ont. Metal Products Co., ${ }^{241}$ as follows: ${ }^{242}$

... it is a question of fact in each case whether, if the facts concealed or misrepresented had been truly disclosed, they would, on a fair consideration of the evidence, have influenced a reasonable insurer to decline the risk or to have stipulated for a higher premium.

Henwood v. Prudential Ins. Co., 243 recently decided by the Supreme Court of Canada, has appeared to lessen the burden of proof on the insurer inasmuch as it can prove materiality by calling its own officials and adducing evidence as to its own practice. The onus of proving that the practice was unreasonable, or that other insurers follow a different practice has, apparently, been shifted by the Supreme Court to the plaintiff. This is a comparatively heavy burden to discharge. It is easy for the individual insurer to ascertain the practice of other insurers because of frequent communication among themselves and accessibility to the underwriting statistics. Conversely, an insured layman or a beneficiary lacks the means to prove reasonable insurance practice.

In the Henwood case, the insured, in answer to direct questions, failed to disclose a medical consultation with a psychiatrist and the nervous disorders from which she suffered for over a year. The insured was a frail young woman of 20 years of age at the time of application for insurance. Two years before the issuance of policy she had romantic problems due to breaking off her engagement following religious differences with her fiance, which caused her a mild nervous condition and later resulted in consultation with a psychiatrist. She had, however, fully recovered from the nervous disorders before applying for insurance coverage. The insured, while travelling in a car as a passenger, died in a traffic accident. Although the circumstances of the death had no connection whatever with the non-disclosure or misrepresentation, the insurer contended that disclosure of nervous disorders might have led to the rejection of the risk or stipulation of higher premium. The trial judge found that the plaintiff could not contradict the testimony of the insurer's senior officials regarding the materiality of the facts in question. On appeal to the Supreme Court of Canada, which found for the insurer, Ritchie J. made the following comments:244

... a misrepresentation is not necessarily 'material to the insurance' simply because it has been elicited in answer to a question devised by the insurance company but in a

240 Daviau v. Can. Order of Foresters (1923) 61 Que. S.C. 492.

241 [1925] A.C. 344, [1925] 1 D.L.R. 583, [1925] 1 W.W.R. 362, affirming [1924] S.C.R. 35, [1924] 1 D.L.R. 127, which rev'd. 54 O.L.R. 299.

242 Id. at 351-2.

243 Supra, n. 198

24 Id. at 726. 
case where senior officials of the company testify that untrue answers given by an insured would have effected the rate and the risk, there is, in my opinion, evidence that these answers bore a direct relation to the acceptance of the risk by the insurer.

As to the materiality of facts to the insurer and the absence of evidence on the part of the plaintiff showing the unreasonableness of the insurer's practice or its inconsistency with the practice of other insurers, Ritchie J. said:245

If the matters here concealed had been truly disclosed they would undoubtedly have influenced the respondent company in stipulating for a higher premium and as there is no evidence to suggest that this was unreasonable or that other insurance companies would have followed a different course, ... it has been affirmatively shown that untrue answers respecting the medical advisers consulted by the insured were material to the risk. This is enough to avoid the policy.

The dissenting opinion of Spence J. merits attention. That learned judge points out that the testimony of the company's officials as to the materiality of non-disclosure was based on the practice of the respondent alone and that the officials expressed ignorance about the practice of other insurers. This led him to make the following observations:246

... the evidence given by Dr. Roadhouse and by Miss Degnan [Company's officials] cannot be accepted as a discharge of the onus upon the insurer to prove that if the facts had been truly represented they would have caused a reasonable insurer to decline the risk or required a higher premium ... these two witnesses not only testified as to the policy of their own company but testified that they had no knowledge of the policies of other insurers. This, therefore, would require the court to hold that the respondent in reciting its policy automatically recites the policy of a reasonable insurer.

As to the opinion of Ritchie J., it is respectfully submitted that the acceptance of the testimony of one insurer's officials without requiring them to prove that their practice was consistent with other reasonable insurers would lead to the replacement of the "reasonable insurer" test of materiality, as laid down in Mutual Life Ins. Co. v. Ontario Metal Products, ${ }^{247}$ by a test of the "particular insurer". The burden of proof as discussed earlier is unduly shifted to the plaintiff. It has been suggested by the Editor, Canadian Abridgment 248 that the Henwood case "does not deny the validity of this test [reasonable insurer's test] but leaves it open to the insurer to establish what a 'reasonable insurer' would do by reference to its own practice." It should be noted that the respondent did not establish that a "reasonable insurer" would have acted in the same manner as he did. There must be a positive proof adduced by a particular insurer of the practice of the "reasonable insurer" before there can be a sufficient discharge of the onus that devolves upon him. Moreover, the courts should examine the reasonableness or otherwise of the practice.

\section{The Editor also makes the following statement: ${ }^{249}$}

Later cases have concentrated on the 'reasonable insurer' as defined by industry practice, and it has usually been thought desirable to have the opinion of industry representatives not employed by the insurer involved in the litigation.

It is not evident from the cases reported in the Abridgement under

\footnotetext{
$245 \mathrm{Jd}$. at 727.28 .

246 Id. at 737-38.

247 Supra, n. 241.

24* 20 Can. Abr. (2d) at 419.

249 Id.
} 
the heading "Materiality" whether the opinion of industry representatives as mentioned above has been solicited and accepted. Such a change in judicial outlook would certainly be for the better, but it would not alleviate the problem completely, so long as materiality is assessed strictly from the insurer's point of view.

C. Automobile Insurance

1. Non-disclosure

Section 287 of the Alberta Insurance Act, ${ }^{250}$ which deals with misrepresentation and non-disclosure in automobile insurance provides:

(1) Where,

(a) an applicant for a contract,

(i) gives false particulars of the described automobile to be insured to the prejudice of the insurer, or

(ii) knowingly misrepresents or fails to disclose in the application any fact required to be stated therein,

or

(b) the insured contravenes a term of the contract or commits a fraud, or

(c) the insured wilfully makes a false statement in respect of a claim under the contract,

a claim by the insured is invalid and the right of the unsured to recover indemnity is forfeited.

Other provinces have promulgated similar legislation..$^{251}$

The cases dealing with non-disclosure and misrepresentation will be discussed separately. Certain cases will, however, be grouped under a general heading because either non-disclosure was held to amount to misrepresentation or the courts did not draw a clear distinction between the two. Case law on non-disclosure will be taken up first.

The driving record of the insured is regarded as a circumstance material to the acceptance of the risk and specific questions are asked as to previous motor vehicle accidents, claims made by and against the insured, driving convictions, cancellation or suspension of licences, permits, registration certificates and fines.

\section{(a) Previous accidents}

If an applicant for automobile insurance "knowingly" fails to disclose his driving record it invalidates his right of recovery under the policy. Where, however, an insurer, after becoming aware of insured's nondisclosure, does not repudiate the policy, the insured may have a cause of action based on acquiescence if he takes up that position in his pleading. In Silcock v. Co-op Fire \& Casualty Co., ${ }^{252}$ the insured failed to disclose that he had been involved in an accident while driving a government dump truck. The insured was involved in another accident following issuance of the policy. The insurer then learned about the previous accident and verbally informed the insured, through his employee, that the policy was invalid. Notice of cancellation of the contract together with return of the premium in full was made six weeks after the date of the accident, although the insurer had received an abstract of the driving record of the insured. The jury found that the insured had failed to disclose a material fact but held that the insurer had acquiesced in the insured's dishonesty to the prejudice of the insured.

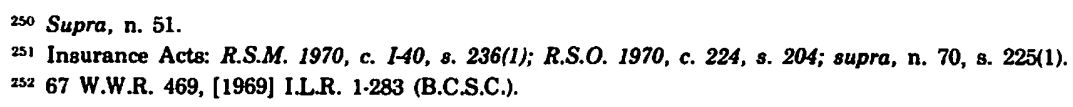


On appeal to Supreme Court of British Columbia, Wooton J., commenting on the conduct of the insurer, said: ${ }^{253}$

The acquiescence of the defendant, if any, may give the plaintiff a cause of action, but he did not plead that and cannot set up a claim by way of reply.

As to the cancellation notice and invalidity of the claim, the learned judge remarked: ${ }^{254}$

There was no obligation upon the defendant to give notification that it cancelled the policy. It could have done that but relied instead on the Insurance Act, sec. 225 [deal-

ing with knowledgeable misrepresentation or non-disclosure], to make the claim to in-

demnity by the plaintiff invalid.

The appeal of the plaintiff was, therefore, dismissed on the ground that his right of indemnity was forfeited by the statute at the time when he had made a misrepresentation or failed to disclosed material facts in the application. The insurer's failure to repudiate the contract after it had become aware of non-disclosure or misrepresentation did not help the insured.

Although the applicant must truly state facts in response to direct questions in the proposal form put by the insurer, when the latter has obtained an abstract of the driving record of the former, the insurer should be estopped from pleading non-disclosure or misrepresentation. Insurance companies should not accept the premium and utilize it to their advantage only to assert that the claim is invalid after a loss.

It has been seen that a misrepresentation or failure to disclose material facts made "knowingly" will render a claim for indemnity invalid. If, however, the non-disclosure results due to the fact that the applicant was misled by the agent who had apparent authority to bind the company, the insurer would be liable. In Compagnie Equitable v. Gagne, ${ }^{255}$ the applicant truthfully represented to the agent of the insurer, who had apparent authority to bind the company, that he had been involved in two accidents, one of which he had paid the damages of $\$ 65$ out of his own pocket, and the other no damage to the person or property of a third party was involved. The defendant's agent told the applicant that he did not have to reveal the two accidents for the reasons explained to him. Following an accident, the insurer brought an action for a declaration that the automobile policy issued by it was void for misrepresentation. The action was dismissed and the insurance company appealed to the Quebec Court of Appeal. Choquette J. adopted the opinion of Hyde J. in Great-West Life Assurance Co. v. Paris: ${ }^{256}$

...the insurer's agent was his duly authorized representative for the purpose of soliciting and receiving applications for insurance and as the insurer had not taken the precaution of indicating in the form that the agent had no authority to interpret or advise in connection with the question asked therein, the agent's action in doing so was within his apparent authority and the applicant was entitled to assume that he could rely upon his assistance. The insurer is bound by the act of its agent within the scope of his apparent authority and cannot complain of the answer given.

After citing a number of authorities as to the effect of explanations given by insurer's agents, the learned judge quoted McGillivray on Insurance Law:257

233 Id. at 480 .

2s. Id. at 482 .

2ss (1966) 58 D.L.R. (2d) 56 (Que. C.A.).

2s6 [1959] Que. Q.B. 349 at 349-50.

25? 1 McGillivray on Insurance Law at 483-4 (5th ed.). 
If the agent has authority to negotiate and settle the terms of the proposal, he must by necessary implication, have some authority to explain the matter to the applicant.

The decision makes it clear that where the applicant is misled by the insurer's agent having ostensible authority, as to the requirements of the insurance company, and relies upon the agent's explanation, the insurer cannot avoid coverage on grounds of non-disclosure or misrepresentation. The case must, however, be distinguished from a situation where concealment or misrepresentation has resulted due to the complicity of the agent and the insured. In Abbi v. Klippert and State Farm Fire and Casualty Co.,258 which will be discussed in detail under the heading "Misrepresentation", the agent had told the applicant to report one accident instead of two to enable him to obtain insurance and the applicant acted accordingly. The claim of the insured was invalid but he succeeded on other grounds. ${ }^{259}$

\section{(b) Suspension of driving licenses}

An insured is required to disclose in his application for automobile insurance any suspension or cancellation of his license. The duty of disclosure, however, is not restricted to original applications for insurance. The insured is required to communicate, at the time for the renewal of his insurance, any cancellation or suspension which has taken place prior to renewal. In Turgeon v. Atlas Ass. Co., ${ }^{260}$ a Quebec case, the insured was issued a policy of automobile insurance on the strength of an application containing the declaration that his driver's permit had not been suspended during the preceding three years. Before the renewal of the policy, the insured's driving license was suspended for impaired driving, but he failed to disclose this to the insurer until after the accident giving rise to the claim. The renewal signed by him provided that the insured reaffirmed as of the day of renewal the representations contained in the original application. The insurer refused to pay an injured third party victim on the ground that the omission constituted an important and pertinent material fact of such a nature as to diminish the appreciation of the risk.

The Superior Court awarded judgement in favour of the insured by declaring that the policy and certificate of renewal were in force on the day of the accident. This was reversed by a majority judgment of the Court of Appeal. An appeal to the Supreme Court of Canada was dismissed. The headnote reads: 261

Per Fauteux, Martland and Judson JJ.: 'By accepting the renewal without revealing that his permit had been suspended, the defendant Fortin misled the respondent company ... The company must not suffer the consequences of the defendant's failure to read the policy which he signed and the certificate of renewal which he accepted, and his good or bad faith is of no importance'....

The dissenting opinion of Hall and Pigeon JJ. is worthy of attention:262

In the application signed by the insured, there is nothing which is likely to inform the insured that he must disclose a suspension occurring subsequently. Furthermore, there is nothing susceptible to take away the impression arising from the rider printed on

2s.M 68 W.W.R. 426, [1969] I.L.R. 1-286 (Alta. S.C.).

2sy Id.

260 [1969] S.C.R. 286, [1969] I.L.R. 1.259 (sub. nom. Turgeon v. Fortin).

261 Id. at 288.

$262 \mathrm{ld}$. 
the policy as well as from the marginal notes, that the insured was not obliged to disclose suspension of his permit.

The Supreme Court of Canada, in a majority judgment, dismissed the appeal of the insured on the ground that the company must not suffer the consequences of plaintiff's failure to read the policy and the certificate which he signed. Since the non-disclosure had resulted in the diminution of the appreciation of the risk, the insured's good faith or bad faith was of no consequence. The result is undesirable in that the third party victims were unable to recover from the insurer.

If this case had arisen in the Provinces of Alberta, British Columbia, Manitoba or Ontario, it appears that the insurer could not avoid the claim. The insured in automobile insurance in these Provinces is only under a statutory duty "to disclose in the application any fact required to be stated therein."263 This may imply that where the insurer does not require a de novo application, there is no statutory duty to disclose suspension or cancellation of a driving license. This should be made clear by legislation.

It is submitted that the insurer should require a de novo application from the insured if he wants the disclosure of intervening suspension or cancellation of driving licenses. In Quebec, however, the insurer should make it prominently clear in the application form that certain facts occurring after the grant of insurance should be communicated on renewal.

(c) Cancellation of previous insurance

Cancellation of previous insurance by other insurers, of a similar class as applied for, is regarded as a material circumstance because its truthful disclosure may lead the insurance company to investigate the reasons responsible for cancellation. Courts have, however, taken a strict view of the term "cancellation" as requiring a unilateral action by the insurer or insured. Where the insurance company asks its agent to obtain the policy for cancellation and the insured willingly returns the same, it does not constitute cancellation in the strict sense of the term. The insurer or insured must exercise the statutory right giving or demanding a stipulated period of notice to effect cancellation.

In Offstein v. Sweet, Halifax Ins. Co., ${ }^{264}$ an Ontario case, the insurer alleged that the insured had failed to disclose the cancellation or refusal of previous insurance; whereas the plaintiff believed that he had not actually been refused a policy nor that any policy in his favour had been cancelled. The plaintiff had placed insurance with another company which later asked its agent to obtain the policy from the insured as it did not consider the risk desirable. This was not explained to the plaintiff but the policy was returned by him. The plaintiff, while applying for auto insurance through the defendant's agent, explained this to the agent. The latter wrote "No" to the question: "Has any insurer cancelled, declined or refused to renew or issue automobile insurance to the applicant?" The application did not require anything more than a simple answer "No" and this answer was given by the applicant. The insurer denied indemnity to the collision victims and was added as a third party by the insured. Urquhart J., in determining the purport of the word "cancellation", observed:265

26:1 Insurance Acts: Supra, n. 51, s. 287(I)(a)(ii). For text of the section see note 250; Supra, n. 70, s. 225(1); R.S.O. 1970 , c. 224 , s. 204 ; R.S.M. 1970, c. I-40, s. $236(1)$.

254 [1948] O.W.N. 22, 14 I.L.R. 239, reported under the name of Offstein v. Sweet.

265 Id. at 27. 
Cancellation ... implies unilateral and not mutual action. Mutual action by Bryson [the agent] and Sweet [the insured], such as is described by the evidence, is not cancellation .... what amounts to cancellations being a conclusion of law-a layman, ... could not be expected to supply the answer.

The Ontario High Court of Justice found that the insured was entitled to be indemnified against judgment which might be obtained by the plaintiff against him. Apart from the interpretation of the word "cancellation", this finding was also reached on the ground that the insured had been lulled into a false sense of security by the issuance of a policy and insurer's failure to make investigations and repudiate the contract. The contra proferentem rule of construction was applied against the insurer, thus preventing it from avoiding liability. This rule of construction is a useful tool which may allow the courts to give the insured a reasonable degree of contractual security.

An opportunity will now be taken to discuss the case of Ellis v. London-Canada Ins. Co., ${ }^{266}$ which was decided by the Supreme Court of Canada on somewaht similar facts as Offstein v. Sweet, but with different results. In the Ellis case, the insured, to the knowledge of insurer's agent, had untruthfully represented that he was never denied any coverage for automobile insurance and had no license suspensions. After the issuance of the policy, the insurer instructed its agent to procure the policy for cancellation as the risk was not desirable. No written notice of cancellation was given to the insured. The agent wrote a letter to the insured requesting immediate surrender of the policy without assigning any reason therefor, which request the latter complied with promptly without requiring the defendant to serve fifteen days statutory notice for unilateral cancellation. ${ }^{267}$ The insured received the refund of premium and realized the proceeds of the cheque before the date of the accident, the subject of litigation. Following the insured's involvement in a serious accident giving rise to a third party claim, an action was brought against the insurer to recover the judgment obtained against the insured. The insured was successful at trial but the appeal was decided against him, as discussed in detail later. ${ }^{268}$ On further appeal, the Supreme Court of Canada found for the insurer on the ground that the statutory notice of fifteen days is only required in cases of unilateral action, whereas here the cancellation was effected through mutual agreement and before the date of accident. The results were unfortunate because the third party victims failed to recover the judgment from the insurer.

In Offstein v. Sweet, Halifax ${ }^{269}$ the Ontario High Court of Justice had found that the surrender as a result of mutual agreement did not result in cancellation, whereas the findings of the Supreme Court of Canada in the Ellis case are to the effect that the cancellation took place by mutual agreement. If the court had held in the Ellis case that the insurer was under a statutory obligation to serve fifteen days' notice, the accident giving rise to the claim would have been covered and the interest of third parties protected.

266 [1954] 1 D.L.R. 785 (S.C.C.).

267 Ontario Insurance Act, R.S.O. 1970, c. 224, 8. 205, Statutory Condition \#8 provides:

(1) This contract may be terminated,

(a) by the insurer giving to the insured fifteen days' notice of termination by registered mailor five days' written notice of termination personally delivered;

(b) by the insured at any time on request.

26" See note 366 , post.

269 Supra, n. 264. 
It is submitted that either there should be a prominent statement in the policy declaring the statutory rights of the insured, or in the absence of such instructive material in the policy or proposal form, the statutory obligations devolving upon the insurer must be strictly enforced for the protection of the interests of the insured and third parties. The fifteen days' notice period should apply to all terminations of coverage, whether effected unilaterally or by mutual consent.

\section{(d) Concurrent insurance}

The existence of additional concurrent insurance covering the same property, peril and interest must be disclosed to enable the insurers to determine their proportionate liability in the event of loss. The insured, however, cannot be allowed to recover in full on all the policies. In Ontario, prior to 1937, a concurrent insurance had the effect of avoiding liability under either of the policies. Statutory condition $6(1)(e)$ of the Ontario Insurance Act $^{270}$ then provided:

(1) Unless otherwise specifically stated in the policy, or endorsed thereon, the insurer shall not be liable;

(e) if at the time a loss, damage or accident occurs there is any other insurance, of the same interest, whether valid or not, covering said loss or damage, or any portion thereof, which would have been in force if this insurance had not been effected.

The case of Autobus \& Taxi Ltd. v. The Homestead Fire Ins. Co. of Baltimore ${ }^{271}$ was decided under the above statutory condition and the insured was unable to recover under either of the policies because of nondisclosure of existing insurance. The plaintiff had purchased a bus coach under a conditional sales contract which was assigned to Acceptance Corporation for advances made. The bus was at first insured with Globe \& Rutgers and subsequently with Homestead in favour of plaintiff. Secondary insurance was necessitated because of refinancing of the original purchase, and the Acceptance Corporation had made arrangments with Homestead to issue master policies and also specific policies. The bus was destroyed by fire and the action against Globe was dismissed. Held by Masten J.A. of the Ontario Court of Appeal:272

No liability of the defendant, The Homestead Company, arose under the specific policy issued by it, such liability being voided by statutory condition 6(e) owing to the concurrent insurance in the Globe \& Rutgers Company.

The results were that the insured was not able to recover from either insurer. The position has since changed and the insurer is now liable for a rateable proportion of the loss. Subsection 224(4) of the Ontario Insurance Act $^{273}$ provides:

Where indemnity is provided to the insured under two or more contracts and one or more of them are excess insurance, the insurers shall, as between themselves, con. tribute to the payment of expenses, costs and reimbursement for which provision is made in section 212 in accordance with their respective liabilities for damages awarded against the insured.

Other provinces have enacted similar legislation. ${ }^{274}$

The secondary insurance in the above case was not an attempt on the

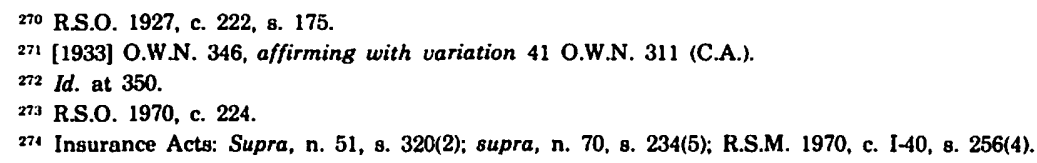


part of the insured to deceive either insurer but was necessitated as a result of refinancing of the purchase. Since the finance company had made arrangements with the second company, the purchaser had to take another insurance policy and while taking the second policy he did not know that he was required to disclose the first one.

The problem stems from the fact that materiality is judged from the insurer's point of view, and although the insured may be in possession of the facts, he does not know their significance from the insurer's point of view. The insured in the above case perhaps did not know that he was required to disclose the first insurance. Section 286(5) of the present Alberta Insurance Act, ${ }^{275}$ requires the insurer to print in a conspicuous manner the provisions of section $287(1)^{276}$ on every application form for automobile insurance and policy therefor. These sections read:

286(5) Upon every application form and policy, there shall be printed or stamped in conspicuous type a copy of section 287 , subsection (1).

287(1) Where,

(a) an applicant for a contract,

(i) gives false particulars of the described automobile to be insured, to the prejudice of insurer, or

(ii) knowingly misrepresents or fails to disclose in the application any fact required to be stated therein,

... a claim by the insured is invalid and the right of the insured to recover indemnity is forfeited.

Legislation similar to section $286(5)$ exists in other provinces. ${ }^{277}$

The Legislature of Alberta, by enacting section 223(1), requires that statutory conditions dealing with the duty of disclosure in fire insurance be printed on every policy. The conditions are, however, not required to be published on the application forms. The applicant for insurance cannot therefore know about them until after the policy is issued.

Similar provisions exist in other provincial Insurance Acts. ${ }^{278}$

Section 286(5) of the Alberta Insurance Act, dealing with automobile insurance, is therefore to be preferred, inasmuch as it requires that the section regulating the duty of disclosure be printed on every application form and policy. Insurance companies should be penalized for failing to do so. It is submitted that this requirement should also be extended to fire and life insurance application forms.

Apart from the above anomalies, it appears that no attempt has so far been made either by the legislatures or by the insurers to point out to the insuring public what facts are material, disclosure of which is essential at the time of original application for insurance or upon renewal.

\section{Misrepresentation}

Where an applicant "knowingly" misrepresents any fact required to be stated in the application, such a misrepresentation may effect his right of recovery under the policy. A motor vehicle collision victim is protected from the effect of such a misrepresentation unless the misrepresentation has resulted in the issuance of a liability policy to a person other than the real owner of the vehicle. Cases dealing with the effect of misrepresentation on the applicant and the victims will now be discussed.

\footnotetext{
${ }_{275}$ Supra, n. 51.

276 Id.

277 Insurance Acts: R.S.M. 1970, c. I-40, s. 235(5); R.S.O. 1970, c. 224, s 203(5); supra, n. 70 s. 219(6).

${ }^{274}$ Insurance Acts: R.S.M. 1970, c. I-40, 8. 142(1); R.S.O. 1970, c. 224, 8. 122(1); supra, n. 70, 8. 208(1)
} 


\section{(a) Effect on applicant}

In Sleigh v. Stevenson, 279 the plaintiff, in an application completed by the agent and signed by her without reading it, misrepresented the ownership of the vehicle and her occupation. In fact, her son was the real owner of the car at all material times, but the car was registered in her name. The plaintiff's son, while driving the car, was involved in an accident. Following a claim by the insured, the insurer denied liability and forwarded a cheque for the full amount of premium to the insured. The action by the plaintiff was dismissed by the trial court. On appeal to the Ontario Court of Appeal, it was held by Kellock J.A.:280

... that no person other than the owner may register under the Act [Highway Traffic Act, 8. 3(1)] and the statement in the application that the appellant was the registered owner was not true in the sense that the appellant, as the person entitled to register, had obtained registration.

As to the effect of misrepresentation and whether they were made "knowingly", the learned judge remarked:281

If Magee was the agent of the appellant in filling the application, as I think he was, the answers are her answers and she knew, as she admits, that they were not correct ... I think 'knowingly' in the statute is used in the sense that the applicant is in possession of information that what is in fact stated in the application is untrue or does not disclose the truth.

The case stands as authority for the proposition that where a person signs an application form which contains untrue statements he makes a misrepresentation within the meaning of statutory condition 1 , although the application has not been completed by him or read over to him before he signs. His signature is a corroboration of the authenticity of the statement made therein.

\section{(b) Misrepresentation as to ownership}

Section 287 of the Alberta Insurance Act, 282 and similar provisions in other provinces, ${ }^{282}$ provide that knowing misrepresentations of facts required to be stated in the application for automobile insurance renders a claim by the insured invalid. This may imply that the interest of third party accident victims is protected despite the non-disclosure or misrepresentation made "knowingly" by the insured. An attempt will now be made to analyze how far the statutory provisions and the efforts of the judiciary have protected the interest of innocent third party motor vehicle collision victims.

The user of a motor vehicle, under section 3 of the Fatal Accidents Act, ${ }^{284}$ is liable to action for damages in respect of the death of a person caused by his wrongful act, neglect or default while operating the motor vehicle. This legal liability imposed on the user of a motor vehicle is covered by the issue of an owner's policy under section 290 of the Alberta Insurance Act, ${ }^{285}$ which provides:

290(1) Every contract evidenced by an owner's policy insures the person named therein and every other person who with his consent personally drives an

279 [1943] 4 D.L.R. 433, [1943] O.W.N. 465, 10 I.L.R. 287, affirming [1943] O.W.N. 292, 10 I.L.R. 246.

200 Id. at 440.

281 Id. at 441.

283 Supra, n. 51.

283 Insurance Acts: Supra, n. 70, s. 225(1). R.S.M. 1970, c. I-40, s. 236(1); R.S.O. 1970, c. 224, 8. 204.

284 R.S.A. 1970, c. 138. Other provinces have promulgated similar legislation. See Fatal Accidents Acts: R.S.M. 1970 , c. F-50, s. 3(1); R.S.O. 1970 , c. 164 , 8. 2.

2ns Supra, n. 51. Similar provision exists in other provincial Insurance Acts: Supra, n. 70, s. 232(1); R.S.M. 1970, c. $1-40$, s. $239(1)$; R.S.O. 1970 , c. 224 , s. $207(1)$. 
automobile owned by the insured named in the contract and within the description or definition thereof in the contract against liability imposed by law upon the insured named in the contract or that other person for loss or damage,

(a) arising from the ownership, use or operation of any such automobile, and

(b) resulting from bodily injury to or the death of any person, and damage to property.

This section makes it clear that the policy issued in owner's form covers the person named therein and every other person who with his consent personally drives the automobile. A problem arises where the true owner, for one reason or another, does not arrange insurance in his own name but enters into a sham transaction with another, who, for the convenience of the true owner, becomes a supposed owner. Application for automobile insurance is then made by the supposed owner who falsely represents himself to be the true owner. The supposed owner has neither true ownership nor control of the use of the vehicle, and cannot give or withhold permission as to the use of the vehicle by the true owner or any other person. Moreover, he has no insurable interest in the motor vehicle. By virtue of section 290 of the Alberta Insurance Act, ${ }^{286}$ the automobile policy issued to the supposed owner is not an owner's policy and therefore does not provide coverage either to him or to the true owner. It does not provide coverage to the true owner against legal liability because the true owner is not a named insured and cannot be said to be driving the motor vehicle with the permission of the supposed owner as the named insured. It does not cover the supposed owner because he has no insurable interest. Whether the right of innocent third party collision victims is protected or not in such an eventuality will be analyzed in the light of statutory protection afforded to the third parties and the judicial precedents in that area.

Section 306 of the Alberta Insurance Act deals with the rights of third party collision victims. Subsections (1) and (4) of this section provide:

(1) Any person who has a claim against an insured for which indemnity is provided by a contract evidenced by a motor vehicle liability policy, notwithstanding that such person is not a party to the contract, may, upon recovering a judgment therefor in any province or territory of Canada against the insured, have the insurance money payable under the contract applied in or towards satisfaction of his judgment and of any other judgments or claims against the insured covered by the contract and may, on behalf of himself and all persons having such judgments or claims, maintain an action against the insurer to have the insurance money so applied.

(4) The right of a person who is entitled under subsection (1) to have insurance money applied upon his judgment or claim is not prejudiced by

(a) an assignment, waiver, surrender, cancellation or discharge of the contract, or of any interest therein or of the proceeds therof, made by the insured after the happening of the event giving rise to a claim under the contract, or

(b) any act or default of the insured before or after that even in contravention of this Part or of the terms of the contract,

and nothing mentioned in clause (a), (b) ... is available to the insurer as a defence in an action brought under subsection (1).

Section 306(5) of the Alberta Insurance Act 287 prevents an insurer from taking a defence that a policy issued by it as a motor vehicle liability policy is not such a policy. The subsection provides:

It is not a defence to an action under this section that an instrument issued as a motor vehicle liability policy by a person engaged in the business of an insurer and alleged

${ }^{2 m 6}$ Supra, n. 51.

${ }^{2 k 7}$ Id. 
by a party to the action to be such a policy is not a motor vehicle liability policy, and this section applies mutatis mutandis to the instrument.

Provisions similar to sections 306(1), (4) \& (5) are to be found in other provincial Insurance Acts. ${ }^{288}$

An action is brought for damages either by the injured party or the representatives of the deceased victim under section 3 of the Fatal Accidents Act ${ }^{289}$ to recover judgement against the negligent insured responsible for the mishap. In case of his death, an action is brought against his estate. Upon recovering a judgment against the insured or his estate, the aggrieved party then proceeds ${ }^{290}$ under section $306(1)$ of the Alberta Insurance Act to recover the same from the insurer of the negligent driver, i.e., the tortfeasor. The third party victim may then be met with a defense by the insurer that the policy issued as a motor vehicle liability policy is not an owner's policy as explained earlier. ${ }^{291}$ The only protection available to it is enshrined in section $306(4)$ as set forth above. The subsection is wide enough in its import to cover any failure of the insured to truthfully disclose or misrepresent material facts in the application form. In case of any act or default of the insured either before or after the accident which is covered by section $306(4)(\mathrm{b})$, the victim is entitled to recover from the insurer the judgement obtained by him against the tortfeasor. The insurer will then be entitled to reimbursement from the insured under section 306(13) of the Alberta Insurance Act ${ }^{292}$ because the insurer was not otherwise liable to pay on account of the insured's non-disclosure or misrepresentation. The said section provides:

(13) The insured shall reimburse the insurer upon demand in the amount that the insurer has paid by reason of this section and that it would not otherwise be liable to pay.

The right of recovery of victims is based on section 306(1) of the Alberta Insurance Act. The third party can only recover from the tortfeasor, i.e., the negligent insured, a claim "for which indemnity is provided", but if the insurance contract does not provide coverage the third party cannot recover from the insurer any claim on behalf of the insured. The position has been aptly summarized as follows. ${ }^{293}$

If there is a misrepresentation or failure to disclose a material fact which is not included in the standard application form, this affects neither the victim's nor the insured's insurance coverage. If there is misrepresentation or failure to disclose a material fact which is included in the standard contract or a breach of condition by the insured, under all provincial statutes this does not deprive the victim from collecting the insurance proceeds, but does give the insurer a right to recover over against the insured. If the loss is occasioned by conduct beyond the definition of the risk, there is no coverage for the insured and hence no right of recovery by the victim.

Having set forth the statutory provisions we now proceed to analyze the case law.

${ }^{288}$ Insurance Acts: R.S.M. 1970, c. I-40, 8. 258(1); R.S.O. 1970, c. 224, 8. 255(1), supra, n. 70, 8. 242.

289 Supra, n. 284.

200 Legislation is on the anvil stipulating only one action by the victim against the insured by making liability of the insurer absolute without the necessity of further action against the latter. This would apply only in cases where coverage is provided by the liability policy of the tortfeasor. Proposed amendment to section 225 , Ontario Insurance Act, 1970, the equivalent of subsection 306(1) of the Alberta Insurance Act, R.S.A. 1970, c. 187, provides: ". . . all sums are payable by the insurer without the necessity of any judgement being obtained against the insurer." See Kesolution 18, Proceedings of 1973 Meetings of the Association of Superintendents of Insurance of the Provinces of Canada.

291 Supra, n. 285.

292 Supra, n. 51. Other provinces have made corresponding provisions in their provincial Insurance Acts: R.S.M. 1970, c. I-40, 8. 258(13); R.S.O. 1970, c. 224, 8. 225(3), supra, n. 70, 8. 242(8).

293 Baer, Insurance Law, (1973) 6 Ottawa L. Rev. 193 at 201. 
In Comer v. Bussell, ${ }^{294}$ one Johnson, the owner of a taxi-cab business, being unable to obtain a driving license due to residence requirements, made arrangement with Seaman, the vendor of the cabs, whereby the cabs and business were ostensibly transferred to the latter. The business was supervised by Johnson as Seaman actually had no connection with it. A motor vehicle liability policy was issued for two taxi-cabs by Lloyds Underwriters on the application of Seaman, who described himself as owner. The plaintiff was injured by the negligence of Kowaluk, the driver of Johnson, and judgement was obtained against the latter two. The judgment remaining unsatisfied, action was brought against the insurer under section 205 of the Insurance Act, 1937,295 the equivalent of subsection 306(1) under the current Alberta Insurance Act. ${ }^{296}$

The plaintiff contended that Kowaluk, the driver, although not nam. ed in the policy, was insured by virtue of section 198 of the Ontario Insurance Act, ${ }^{297}$ i.e., the equivalent of section 290 of the 1970 Alberta Insurance Act. ${ }^{298}$ The section provides indemnity for legal liability not only to the named insured but also to every other person who, with his consent, personally drives the described automobile. Judgement at trial given in favour of the plaintiff was reversed on appeal.

The Court of Appeal held that the automobile policy issued to Seaman was not an owner's policy. An "owner's policy" as defined by section 183 (g) of the Ontario Insurance Act, 1937,299 is a "motor vehicle liability policy insuring a person named therein in respect of the ownership, operation or use of any automobile owned by him and designated in the policy." Seaman was not an actual owner of the cab and, therefore, the policy was not an owner's policy. ${ }^{300}$ Secondly, the Court of Appeal also held that Kowaluk, Johnson's driver, was not a named insured, who could be said to be driving the car with Seaman's permission. . $^{301}$ Kowaluk had, therefore, no right of indemnity under section 98 of the Ontario Insurance Act, 1937, the equivalent of section 290 of the Alberta Insurance Act.

On appeal to the Supreme Court of Canada, judgement was delivered orally by Duff C.J., who said: ${ }^{302}$

There was no contractual relationship between Kowaluk and the Insurance Company, and, therefore, the provisions in the policy taken out by Seaman (apart from the enactments of the Insurance Act) could give Kowaluk no status to sue.

As to the contention of the plaintiff that Kowaluk was driving the cab with the permission of Seaman, the "person named" in the "owner's policy", the finding of the Court of Appeal that the policy was not an owner's policy was upheld. ${ }^{303}$ Consequently, the plaintiff could not recover as a judgment creditor under section 205 of the Insurance Act, 304 the equivalent of section 306 of the present Alberta Insurance Act.

\footnotetext{
294 [1940] S.C.R. 506, 7 I.L.R. 247, [1940] 3 D.L.R. 417, affirming 7 I.L.R. 44, [1940] 1 D.L.R. 97 which rev'd. 7 I.L.R. 49 (sub. nom. Johnson and Kowaluk v. Bussell).

295 R.S.O. 1937, c. 256.

20 Supra, n. 51.

297 Supra, n. 295.

228 Supra, n. 51, for text see n. 285, supra.

209 Supra, n. 295.

300 Supra, n. 294 at 46.

301 Id. at 48.

302 Supre, n. 294 at 509.

${ }^{303}$ Supre, n. 294 at 510

304 R.S.O. 1937, c. 250 . For text of the section see n. 286, supra.
} 
In Minister of Transport v. London \& Midland Gen. Ins. Co., ${ }^{305}$ a motor vehicle liability policy in owner's form was issued to Miss Bassert, the supposed owner of the vehicle. Dolson, the true owner, did not have a driving license and made arrangement for the temporary registration of the vehicle and issuance of the policy in her name. On obtaining the license, the ownership and policy were to be transferred to him.

Dolson, the true owner, while driving the vehicle, collided with another car and was killed in the accident in which third parties sustained injuries. Judgement recovered against the estate of Dolson was paid for by the Minister of Transport who then sought recovery from the insurer. The trial court dismissed the action. On appeal to the Ontario Court of Appeal, Gale C.J.O. stated:306

... if a policy is issued to the owner of a motor vehicle as a result of his misrepresentation, then the fact of the misrepresentation will not provide an insurance company with a defence against third parties who are injured as a result of the operation of the vehicle by the owner.

In the instant case, the policy was not issued to the owner of the vehicle as a result of his misrepresentation but to the supposed owner due to latter's false representation as to ownership.

As regards the question whether the true owner was driving with the permission of the supposed owner, the Chief Justice observed: ${ }^{307}$

This policy does not cover this risk not only because it is not an owner's policy but also because it cannot be said that Dolson had Miss Bassert's consent to operate the car at the time the accident occurred. We say that because she was not in a position to be able to give or withhold consent.

The Minister of Transport who had already paid the judgement to the third party and received an assignment thereof, was unable to recover from the insurer.

The cases of Pascoe v. Provincial Treasurer of Manitoba $a^{308}$ and Peters v. General Accident \& Life Assurance Corporation Ltd., ${ }^{309}$ were cited as authority in the London \& Midland case. ${ }^{310}$

The approach of the Nova Scotia Supreme Court, Trial Division, in protecting the interest of third parties differed in the case of Wolfe $v$. Oliver et al; Co-op Fire and Casualty Co., ${ }^{311}$ from the approach of the courts in Comer v. Bussell and London \& Midland, cases discussed earlier. ${ }^{312}$ The decision in Wolfe v. Oliver appears more favourable to the third party on the point of consent from the owner to the driver. David Oliver was operating a 1967 Ford car when he was involved in an accident resulting in injuries to the plaintiff. The Ford was purchased by David Oliver in his mother's name, i.e., Cleophas Oliver, who had executed a chattel mortgage for financing the car. David's mother had an owner's policy in respect of another vehicle. She obtained coverage for the Ford in her own name by an alteration endorsement to her existing liability policy by representing to the insurer that she would be the

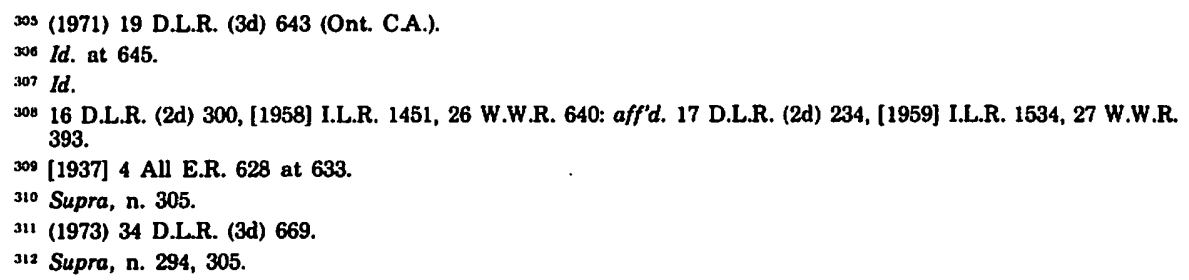


owner of the vehicle. It was agreed between the son and the mother that the former would have the sole control and use of the vehicle. This arrangement was made to secure insurance in the name of the mother at a lower premium.

Before purchasing the Ford, David Oliver held a 1970 Austin in his name and had an owner's policy in respect thereof. He was convicted of impaired driving, and thereafter his driving license was suspended for one year. He made arrangements with his parents whereby they took over the interest in the Austin and assumed liability for instalment payments. No change was, however, made in the registration of the vehicle or the owner's policy in the name of David Oliver. His driving permit was later restored. When he was driving the Ford, the subject of this action, the owner's policy in his name in respect of the Austin was in force. David had not informed his insurers about the change of interest, i.e., that he no longer owned the Austin and had purchased the Ford. The accident took place within two weeks of the purchase of the Ford. Upon giving notice within two weeks of the delivery of the new car to him, David was entitled to cover the newly acquired automobile under his liability policy and to claim indemnity for the accident.

An action was brought by the injured victim against Cleophas Oliver, the mother of David Oliver, as the registered owner of the Ford. Section 221(3) of the Nova Scotia Motor Vehicles Act ${ }^{313}$ provides that the driver is deemed to be the agent of the owner unless the contrary is established. As discussed earlier, the son had sole control and use of the vehicle. Cowan C.J.T.D., of the Nova Scotia Supreme Court, found that the son's authority to use the car was not an authority to use it as a servant or agent of his mother. He also found that the son was operating the car as his own and as of right. 314 The claim of the victim was, therefore, dismissed against Cleophas Oliver as she was not vicariously liable for the negligent driving of her son. The plaintiff was, however, successful against David Oliver.

Cleophas Oliver had an insurable interest in the Ford as she had signed a chattel mortgage and the Ford was a part of the security. Moreover, section 98(5) of the Nova Scotia Insurance Act, ${ }^{315}$ the equivalent of section 306(5) of the Alberta Insurance Act ${ }^{316}$ provides:

(5) It is not a defence to an action under this Section that an instrument issued as a motor vehicle liability policy by a person engaged in the business of an insurer, and alleged by a party to the action to be such a policy, is not a motor vehicle liability policy, and this Section applies, mutatis mutandis to the instrument.

The Chief Justice found that whether or not the mother was an owner or had an insurable interest, section 98(5) prevents the insurer from setting up as a valid defence that an instrument issued as a motor vehicle liability policy is not such a policy.

Section 82 of the Nova Scotia Insurance Act, ${ }^{317}$ the equivalent of section 290 Alberta Insurance Act, ${ }^{318}$ provides:

\footnotetext{
313 R.S.N.S. 1967 , c. 191.

314 Supra, n. 311 at 680 .

31 Section 98 of the Insurance Act, as enacted by 1966 (N.S.), c. 79, 8. 4 [now R.S.N.S. 1967, c. 148, 8. 101] proclaimed in force January 1, 1969. For similar provision in other provinces, see supra, n. 288.

316 Supra, n. 51.

317 S. 82 [now 8. 90] of the Insurance Act, enacted 1966 (N.S.), c. 79, 8. 4 proclaimed in force January 1, 1969.

318 Supra, n. 51.
} 
82.(1) Every contract evidenced by an owner's policy insures the person named therein and every other person who with his consent personally drives an automobile owned by the insured named in the contract....

As to the effect of this section, i.e., whether or not the son was an insured person under his mother's policy or driving with her consent, the Chief Justice remarked: ${ }^{319}$

I interpret this [s. 82] as meaning that a person driving the automobile is covered unless he has taken the automobile without the consent of the person named as owner in the contract of insurance. I have no difficulty in coming to the conclusion that David Gerard Oliver was, at all material times, driving the 1967 Ford automobile with the consent of his mother, ... she [having] agreed impliedly to the continued operation of that automobile by her son....

The Chief Justice, therefore, held that the policy issued to Cleophas Oliver, the mother of the defendant, was an owner's policy and that David Oliver was personally driving the automobile with the permission of his mother and was consequently an insured under the policy. He further held that the plaintiff had a claim for which indemnity was provided by a contract evidenced by a motor vehicle liability policy, and that the defences available against the defendant's son were not available against the plaintiff since his claim was within the limits prescribed by section 92 [now section 95] of the Insurance Act. ${ }^{320}$ The plaintiff was able to recover the damages from the insurer.

The claim of David Oliver against the insurer was, however, dismissed because of breach of statutory condition 2(1)(a) by him, i.e., impaired driving at the time of the accident. David was, therefore, required to reimburse the insurer for damages paid by it because of said breach of statutory condition.

This approach is preferable for two reasons. First, the court held that whether or not the registered owner was the real owner, and whether or not she had an insurable interest, the insurer could not argue a valid defence under section 98(5) of the Nova Scotia Insurance Act, that the policy issued as a motor vehicle liability policy was not such a policy. The section was very broadly construed. Secondly, the court found that the driver was operating the vehicle with the implied consent of the registered owner. The courts in Comer v. Bussell and London \& Midland Gen. Ins. Co. ${ }^{321}$ had, however, held that the registered owner who was the supposed owner, could neither give nor withhold any consent; and since the supposed owner had no insurable interest, the policy was not an owner's policy. Further, they had held that the true owner had no contractual relation with the insurer in order to recover.

It is submitted that, in order to protect victims, section $306(5)$ of the Alberta Insurance Act should explicitly provide that an insurer is under an obligation to pay damages to the victims whether the policy issued by it to the named insured is an owner's policy or not. The insurer should, however, be entitled to reimbursement from the insured, i.e., the supposed owner, where he falsely represents himself to be the true owner and thereby induces the insurer to enter into the contract. In that event, the supposed owner will be rightly penalized for making false representations as to ownership.

\footnotetext{
319 Supra, n. 311 at 690.91 .

320 Id. at 692.93 .

321 Supre, n. 294, 305.
} 
In Blair v. Royal Exchange Ass., ${ }^{322}$ the applicant, who wanted to use the car, told the insurer's agent that the car belonged to his son who was away from home. The son had given written authorization to his father to drive the car. The application was completed by the soliciting agent for the insurer who mistakenly described the father as owner of the car. The applicant signed the proposal form without reading it and a policy was subsequently issued naming the father as owner. An endorsement was later issued covering the son as occasional driver for an additional premium. Without notice to, or the knowledge of his father, the son sold the car for another and arranged an endorsement for the substituted car. The son, while driving the new car, was killed in an accident. The plaintiffs, having obtained judgement against the estate of the insured, claimed against the insurer as judgement creditors. The insurer contended that the applicant "knowingly" misrepresented the true facts when he signed the application. This plea was not considered. Hunt J., of the Manitoba Queen's Bench, held that section 215(1) of the Insurance Act, ${ }^{323}$ the equivalent of section 287(1) of the Alberta Insurance Act, ${ }^{324}$ avoids the policy for misrepresentation as against the insured but does not prejudice the claim of third parties as judgement creditors. ${ }^{325}$ Section 227(4) of the Manitoba Insurance Act provides: 326

It shall not be a defence ... that an instrument issued as a motor vehicle liability policy ... is not a motor vehicle liability policy....

An appeal to the Manitoba Court of Appeal was dismissed. Guy J.A., affirming the Queen's Bench judgement, said:327

The defendant company clearly intended to insure them [the father and the son] in some manner, and took a premium from each of them. Equity will not permit the defendant company to say, in effect, 'we took your money but what we gave you for it is worthless.

The case makes it clear that it is only the claim of the insured that will be invalid for misrepresentation and the right of judgement creditors to recover indemnity under section 227 of the Manitoba Insurance act will not be forfeited. The claim of the third party could not be defeated because the policy, irrespective of alleged misrepresentation, was an "owner's policy".

\section{(c) No misrepresentation as to ownership}

It is possible that a misrepresentation as to ownership may not be made in the original application for insurance and yet an endorsement is obtained to the existing policy whereby coverage is transferred in the name of another. Where an insured car is sold and a new vehicle is acquired in the name of another person for the purpose of financing the purchase, and the insurance company issues an endorsement to the existing policy covering the new car and another person as insured, without requiring any application or making an enquiry, the insurer may be estopped from denying liability to motor vehicle collision victims. In Parise v. Canada Security Ass. Co., ${ }^{328}$ the insurance coverage for legal

${ }^{322} 69$ D.L.R. (2d) 340, 65 W.W.R. 511, [1968] I.L.R. 1-205, (C.A.), affirming 67 D.L.R. (2d) 420, 3 W.W.R. 428, [1968] I.L.R. 1-197, (Man. C.A.)

323 R.S.M. 1954, c. 126.

324 Supra, n. 51, for text of the section see supra, n. 276.

325 Supre, n. 322 at 424.

${ }^{326}$ R.S.M. 1954, c. 126. Similar provision exists in other provincial Insurance Acts: R.S.A. 1970, c. 187, s. 306(5); R.S.B.C. 1960 , c. 197 , s. $242(4) ;$ RS.O. 1970 , c. 224 , 8. $225(5)$;

327 Supra, n. 322 at 341.

${ }^{328}$ [1965] 2 O.R. 482, 51 D.L.R. (2d) 193. 
liability and the registration of the car was originally in the name of Sheldon E. Armstrong who was under 21 years of age. Armstrong traded in his old car. In order to facilitate the purchase of the new car, a chattel mortgage was executed by his father although the son undertook to redeem the mortgage. These facts were disclosed to the recording agent of the company who issued three endorsements covering the substitution of the automobile in the name of the father, the increased coverage, and the chattel mortgage. No reduction in premium was made for the inclusion of the insured's father who was over 25 years of age. The endorsements were signed under the signature of the agent who transmitted them to the company.

The insurer knew that the son was under 21 years of age and therefore could not execute the mortgage, yet the insurance was transferred in the name of the father without any written application from the bank or any inquiry conducted by the insurer. The son was killed in a collision which resulted in liability to third parties. Judgement was obtained against the estate of the deceased and then action was brought against the insurer to have the insurance monies applied in satisfaction of judgement. It was held by Moorhouse J., of the Ontario High Court: ${ }^{329}$

In view of the manner in which this transaction was carried out by the company's agent and acquiesced in by the insurer the suggestion of the plaintiff that the insurer intended to insure both the father and the son is entitled to prevail. The endorsements nowhere indicate clearly the son is no longer insured and protected. He was an insured in the policy... If the company wished to rid itself of liability for the son's acts, it should do so clearly, bringing this to the son's notice.

Section 213(4) of the Ontario Insurance Act ${ }^{330}$ provides:

Any person insured by but not named in a policy may recover indemnity in the same manner and to the same extent as if named therein as the insured, and for that purpose shall be deemed to be a party to the contract and to have given consideration therefor.

As to the contention of the insurer that the standard automobile policy is not an owner's policy the learned judge observed: ${ }^{331}$

... the defendant is not entitled to any advantage flowing from such description. If it is intended to be an owner's policy, it should be accurately described ... This subsection [213(4)] omits any mention of "owner's policy". . . the policy in question would effectively protect the son's estate.

The plaintiffs were successful on the ground that the insurer had acquiesced in the manner in which the transaction was carried out. Moreover, the court held that the policy was not described as an owner's policy. The courts in the Comer v. Bussell and London \& Midland Gen. Ins. Co. ${ }^{332}$ cases did not adopt the approach that the policy was not described as an owner's policy. Such an approach would have resulted in the protection of the victims' interest.

(d) Previous accidents.

Misrepresentation of previous accidents is decidedly an important circumstance which affects the rate and acceptance of the risk. An applicant with no claims is a better risk than one who has been involved in a

329 Id. 51 D.L.R. (2d) 193 at 197-198.

330 R.S.O. 1960, c. 190, [now s. 234, R.S.O. 1970, c. 224] Other provinces have enacted similar legislation. See Insurance Acts: R.S.A. 1970, c. 187, 8. 294 R.S.B.C. 1960, c.197, s. 232(4); R.S.M. 1970, c. I-40, s. 243.

331 Supra, n. 328 at $198-99$.

.32 Supra, n. 294, 305. 
number of accidents. Misrepresentation of previous accidents made "knowingly", therefore, will prejudice the claim of the insured. In Lannigan v. United States Fire Ins. Co., ${ }^{333}$ the plaintiff obtained an "Inland Transportation Policy" for collision coverage on a truck. The plaintiff represented to the insurer's agent that he had been involved in two accidents but that no charges had been laid against him. In fact, he had been in nine motor accidents within a period of three years immediately preceding the application for insurance. The truck, while being driven on a snow covered hill, ran off the road and was rendered unfit for further use. The insurer denied liability for the claim arising out of the accident on the ground of misrepresentation. McDonald D.C.J.O., commenting on the effect of misrepresentation on the acceptability of risk, said: ${ }^{334}$

It would seem reasonable that any company with disclosure of an actual record such as is now disclosed, would have assumed lack of responsibility and respect of laws and regulations on the part of the plaintiff, and would have declined to grant insurance.

Where misrepresentation of previous accidents ensues from the complicity of the insurer's agent with the applicant, the agent's knowledge cannot be imputed to the company. The claim by the insured will be invalid, but the insurer may be estopped from denying liability due to its unreasonable conduct in retaining premiums. That was clearly the case in Abbi v. Klippert and State Farm Fire \& Casualty Co., ${ }^{335}$ where the plaintiff had told the insurer's agent that he had had two accidents. The agent, who had an interest in the commission, advised him to report one, since it was the company's policy not to accept insurance if the applicant had two accidents in one year. Thus, the plaintiff reported only one accident in the application. Following issuance of the policy, the insured was involved in an accident. The insurer then learned that the insured had had two previous accidents. It therefore cancelled the policy and retained a portion of the premium. The claim under the policy would have been invalid but for the conduct of the insurer in retaining the premium. It was held by Dechene J., of the Supreme Court of Alberta. ${ }^{336}$

Having elected to cancel the policy on a date following the accident and retained the portion of the premium up to that date, the company affirmed the policy and could not later claim that it was void $a b$ initio.

Section 287(1) of the Alberta Insurance Act ${ }^{337}$ provides that a claim made following a misrepresentation or non-disclosure in the application for insurance "shall be invalid and the right of the insured to claim indemnity shall be forfeited." The insurer may in such case either reject the claim or avoid the contract. If it selects the latter, the court may require the insurer to return the premiums paid by or on behalf of the insured.

\section{(e) Description of vehicle, cost and liens}

The calculation of the premium is based, inter alia, on the model, the year, the actual cost, and the horse-power of the vehicle. The existence of liens is also an important factor to be considered before the granting of insurance. Misrepresentation or non-disclosure of these facts will prevent the insured from exercising his right of recovery under the policy.

\footnotetext{
333 [1956] O.W.N. 469, [1956] I.L.R. 1-225.

334 Id. at 471.

33568 W.W.R. 426, [1969] I.L.R. 1.286 (Alta. S.C.).

338 Id. at 429.

${ }^{337}$ Supra, n. 51; for text of the section see supra, n. 276.
} 
In Holdaway v. British Crown Ass. Co., ${ }^{338}$ a policy was issued on the strength of an application signed by the agent of the insured who, although authorized by the insured, had no writing to that effect. The application contained a misstatement as to model year, the actual cost of the vehicle and previous loss of another vehicle by fire. The insured truck was destroyed by fire, the cause of which could not be ascertained. The insurer successfully denied liability on the grounds above mentioned.

At the time the policy was issued, section 198(d) of the Ontario Insurance Act ${ }^{339}$ provided:

... an insurer shall not effect a contract of automobile insurance unless such insurer has received an application therefor in writing signed by the insured, or by his agent, authorized in writing signed by the insured.

No such authorization in writing was produced, but both the parties relying on the policy sought justice from the court. Latchford C.J.A., dealing with the effect of section 198(d) said: ${ }^{340}$

The section appears to me to be enacted for the protection of both the insurer and the assured. If both choose, as in the present case, not to rely on the prohibition which it contains, it may, in my opinion, be wholly disregarded, and ... the matter in issue falls to be determined on the provisions of the policy itself.

The Appellate Court found that the plaintiff knew the truck was a 1917 model which cost $\$ 5,900$, although he represented it as a 1921 model at a cost of $\$ 7,500$. The Court was of the opinion that such facts were material. Hodgins $J$., of the same court, referred to the principle enunciated in Dworkin v. Globe Indemnity Company ${ }^{341}$ when he stated ${ }^{342}$

... where untrue material statements are shown to have been made in order to induce the issue of a policy of insurance, or fraudulent suppression upon material matters is proved, resulting in the insurance contract being entered into and the policy delivered, then quite apart from any defence based on its terms, the party responsible for such statements or omissions cannot recover upon the contract. It is vitiated by fraud.

The case amply demonstrates the importance of the facts misrepresented; namely, the model year and the actual cost of the vehicle. The year of manufacture of the vehicle is important because of its relevance to cost, horsepower and risk.

Another case which emphasizes the importance of truthful representation of the price paid and amount outstanding on the vehicle merits a brief discussion. In McDonald v. Guildhall Insurance Co., ${ }^{343}$ the defendant successfully contended that the plaintiffs, either by themselves or through the agent, had wrongly answered the questions on the application form as to the price paid for the truck and the amount outstanding thereon thereby inducing the defendants to issue a policy. Lennox J., of the County Court of Vancouver, said:344

... there is no doubt in my mind that the answers to the questions as to the price paid for the truck, the amount paid thereon and the amount outstanding, were such that, had they been truthfully and properly answered, the defendant company would have acted very reasonably in refusing the application.

33957 O.L.R. 70, [1925] 3 D.L.R. 269 reversing 56 O.L.R. 235, [1925] I D.L.R. 386 (C.A.).

339 R.S.O. 1914, c. 183 , 8. 198(d) [enacted 1922, c. 61, s. 14].

340 Supra, n. 338 [1925] 3 D.L.R. 269 at 279.

341 (1921) 67 D.L.R. 404, 51 O.L.R. 159.

342 Supra, n. 338 [1925] 3 D.L.R. 269 at 280-81.

343 (1940) 7 I.L.R. 170 (B.C.).

34, Id. at 171 . 


\section{(f) Other cases}

(i) Insurer's agent not explaining terms:

Where the insurer's agent or the employee of the latter, whose acts the agent adopts, inserts a technical term in the application for insurance but does not explain its import, the insurer may not be allowed a defence to a claim. In Valgardson v. Contingency Ins. Co., ${ }^{345}$ the application required the proposed insured to state the purpose for which the car was to be "chiefly used". The answer of "Pleasure (select)" was written by the manager of the dealership from which the car was purchased, who had completed the application for insurance on behalf of the plaintiff. The manager was an employee of the agent. At the time of the accident the car was driven by plaintiff's foster son who was under 25 years of age. The defendant contended that the word "select" signified that there were no drivers under 25 and that the plaintiff had made material misrepresentation or alternatively had violated the terms of the policy by failing to notify of a change material to the risk.

As to the significance of the word "chiefly", Maybank J., of the Manitoba Queen's Bench, said that the car would be used "chiefly for pleasure and chiefly by a person over 25 years of age"; 346 while, with regards to the word "select" in the rating book, (which was in the present tense-"there are no drivers, etc."), the judge commented that "When the plaintiff wrote the word 'select' into the application and thereby said 'there are no drivers under 25 ' he was stating the absolute truth." 347

The misrepresentation alleged, if any, and if made "knowingly", was not material since the application did not ask any questions about the maturity or immaturity of drivers of the automobile.

Statutory condition 2(1)(b), pursuant to section 185 of the Manitoba Insurance Act ${ }^{348}$ provides:

2.(1) The insured shall not use or drive the automobile,

(b) whilst he is not for the time being qualified and authorized by law to drive or operate the automobile or, in case the law does not prescribe any qualification or authority whilst under the age of sixteen years.

Section 185(1)(b) dealing with a variation or omission of this statutory condition stipulates: 349

No variation or omission of a statutory condition shall be valid nor shall anything contained in any addition to a statutory condition or in the description of the subject matter of the insurance be effective in 80 far as it is inconsistent with, varies or avoids any such condition.

The defendant, therefore, in seeking to delete the number " 16 " and substituting therefor the number " 25 " was asking for the variation of a statutory condition which could not be permitted. ${ }^{350}$

As to the effect of the document prepared by the employee of the insurer's agent, Maybank J. observed: ${ }^{351}$

...Mr. Veitch [the agent] adopted the work on the application for insurance as his

\footnotetext{
sus [1955] I.L.R. 1-199, [1955], 5 D.L.R. 649, 16 W.W.R. 177, (Man. Q.B.).

366 Id. [1955] 5 D.L.R. 649 at 655.

3.: Id. at 656 .

340 R.S.M. 1940, c. 103.

309 Id.

3so Supra, n. 345 [1955] 5 D.L.R. 649 at 658.

ast Id. at 660-61.
} 
own and the application form becomes one made by him, a properly qualified insurance agent of the defendant company ... there is no evidence at all to suggest that the insurer in this case took any steps whatever to bring home to the mind of the insured exactly what he was getting.

The contra proferentem rule was applied. This rule has been explained in this chapter. ${ }^{352}$ Misrepresentation could not be attributed to the insured as the significance of the word "select" was not explained by the insurer's agent to the plaintiff. Moreover, the word implied that "there are no drivers under 25". This was absolutely true when application for insurance was made.

The case makes it clear that, where an insurer's agent has authority to negotiate the terms of the contract, he is authorized to explain the terms and if he fails to discharge his duty, the insurer will be held liable. A reform of the statute law along this line is suggested. It is submitted that this decision is desirable as it protects the insured innocent party from the acts and defaults of the insurer's agent.

(ii) Misrepresentation affecting validity of renewal:

Where the original application contains a false statement as to the suspension of a driving license during the three years immediately preceding, and policies are from year to year, the insurer may not be permitted to establish that it relied on the representations made in the original application and treated all the policies issued thereafter as "renewals" only. In Pengelly v. British Empire Ass. Co.,"353 the insured, in his application for automobile insurance, falsely stated that he had never been disqualified from driving or had had his license suspended. The policy was issued in 1966 and renewed from year to year. The renewal was in force when the plaintiff, a third party victim, was involved in an accident on July 19, 1971. The applicant in fact had his license suspended for two months in 1964. The plaintiff recovered judgement against the insured in 1971 but was unable to recover any amount from him. The plaintiff then sued the insurer. The defendant insurer denied liability on the ground that the succeeding renewals were tainted with false statements due to the untrue statement in the original application.

The insurer required disclosure of license suspensions during the three years preceding the date of the issue of the policy sued on, and since suspension had taken place more than three years before, the insurer was not interested in knowing about it (as was evident from the questionnaire). Tucker J., of the Saskatchewan Queen's Bench, dealing with the insurer's practice in relying on the representations contained in the original application, said: 354

The attempt by evidence to vary the terms of the written document sued on, by showing that it was the practice of the defendant to rely on the representations made at the time of the first application for insurance and to treat all policies issued thereafter as 'renewals' only, was ... improper as an attempt to vary the written document sued on, which plainly states that it replaces No. 9086907 expired.

There was no evidence to show that the insured had knowingly misrepresented or failed to disclose any fact required to be stated in the application deemed to be part of the contract sued and relied upon.

\footnotetext{
isz See discussion following note 265 , ante.

ss: [1973] 6 W.W.R. 68.

ist Id. at 73 .
} 
Tucker J. quoted the following paragraph from the judgement of Guy J.A., in Blair v. Royal Exchange Ass., ${ }^{355}$ as fairly applicable:356

Equity will not permit the defendant company to say, in effect, 'we took your money but what we gave you for it is worthless'.

The Pengelly case case represents good law inasmuch as it shows a greater awareness on the part of the judiciary of the legitimate protection of the interest of the insured and third parties. If the argument of the defendant, that the subsequent policies were merely "renewals" of a void policy, had been allowed to prevail, the consequences would have been disastrous to the insured and the injured victims.

Section 194 of the Saskatchewan Insurance Act ${ }^{357}$ invalidates the claim of an insured if he "knowingly misrepresents or fails to disclose in the application any fact required to be stated therein". The insurer in the above case did not require a fresh application on each renewal. It is submitted that the court, on the basis of strict interpretation of section 194, should have held that since the insurer did not require a de novo application, there was no misrepresentation or non-disclosure "in the application". It is suggested that this section should be strictly construed, and therefore, there should not be any duty of disclosure on each renewal if the insurer fails to require a de novo application. It is preferable, however, that this should be made clear by amending legislation.

In Turgeon v. Atlas Ass. Co., ${ }^{358}$ discussed above, ${ }^{359}$ the insured and the third party had to suffer because of non-disclosure of a license suspension at the time of renewal. The license suspension was made after the issuance of the original policy and before renewal, but the insurer had failed to require a fresh application. It is submitted that the approach of the Saskatchewan Queen's Bench in protecting the interest of insured and accident victims in the Pengelly case is preferable.

(iii) Misrepresentation as to physical disabilities:

The Newshome rule ${ }^{360}$ provides that where an applicant orally furnishes correct answers to the insurer's agent, in response to questions in the application, but the agent fills in incorrect answers, the applicant is responsible for any non-disclosure or misrepresentation therein if the latter signs the form without reading it. The applicant will, however, not be bound by any inaccuracy in the answers if he would not have considered the answers to be false, had he read it. In Lewis v. Northern Assurance Co., ${ }^{361}$ the applicant, a carpenter, explained to the employee of the agent who completed the proposal form, that he had an artificial limb which worked efficiently. The employee answered in the negative the question; "Will the automobile be operated by any person suffering from the loss of a foot or limb?" The applicant signed the form on being told that it only contained; "What I asked you and what you said." The insured also believed that the agent's employee, by writing "No" to the relevant question, placed him in the category of persons who were not suf-

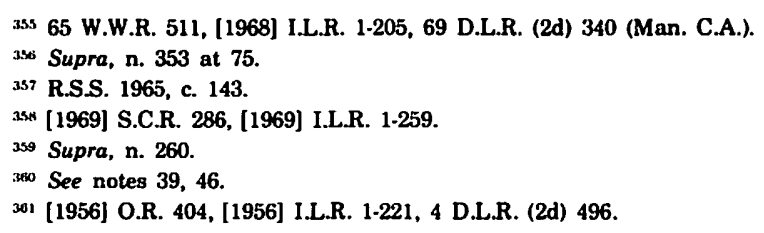


fering from any physical infirmities despite the amputation of his limb because of his efficient use of the artificial limb. The insurer, following a claim involving third parties in an accident, contended that the policy was void $a b$ initio because of the fraudulent misrepresentation of the insured.

The court believed the insured's testimony and rejected that of the agent's employee, who with thirty-four years of experience in the insurance industry, inserted wrong answers in the agent's report. The insured did not "knowingly" misrepresent or fail to disclose in the application any fact required to be stated therein.

Section 214(4) of the Ontario Insurance Act ${ }^{362}$ provides:

It shall not be a defence to an action under this section that an instrument issued as a motor vehicle liability policy by a person engaged in the business of an insurer, and alleged by a party to the action to be such a policy, is not a motor vehicle liability policy, and this section shall apply mutatis mutandis, to the instrument.

Spence J., of the Ontario High Court, commented on the ineffectiveness of the defence: ${ }^{363}$

... the defendant in alleging that the policy is void ab initio is simply using other words to deny that the policy is a motor vehicle liability policy. In my view, the section applies exactly to the present situation, and even had I come to other conclusions as to the facts and as to the effect of the insertion of the word ' $N o$ '... I would have concluded that the defendant's defence was barred by s.214(4) of the Insurance Act.

The case in an exception to the rule that an applicant who signs a proposal form containing false representations is deemed to have "knowingly" made misrepresentations even though he does not know of the falsity of the answers written therein. The reason for the exception is based on the belief by the insured that the answer is not false in view of the conduct of the agent or his employee. The reasoning in the decision protects the interest of the innocent insured and third parties.

(iv) Interim coverage before application containing misrepresentation

Where interim coverage is granted by the insurer prior to the completion of the application by the insured and the intention of the insurer is to keep him covered pending investigations, misrepresentation in the application may not affect the right of recovery under the temporary insurance. In Whitelaw v. Ransom and Wellington Fire Ins. Co., ${ }^{364}$ the insured was issued a pink card with a policy number indicated thereon, providing coverage for the automobile designated in the card. The application containing the misrepresentation was later filled in by the agent who knew that the insured had had his policy cancelled for previous accidents. The application was rejected and the agent was so informed, but no notice of rejection was received by the applicant who five months later was involved in an accident. The insurer denied liability. Judgement was given at trial against the insurer to the effect that the interim insurance was in full force and effect at the time of the accident and the insurer was required to pay. This was affirmed on appeal. Des Brisay C.J., of the British Columbia Court of Appeal, made the following findings as regards the application completed after the grant of interim coverage: ${ }^{365}$

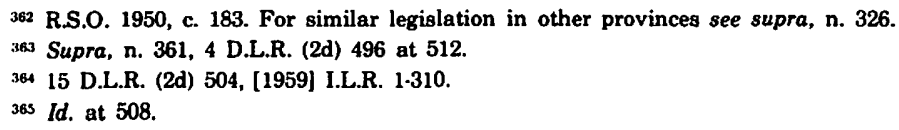


The contract of interim insurance in effect was not that applied for by the written application, nor was the truth of the representation in the written application the basis of the interim coverage, since before the application was completed the appellant instructed Buchanan [the insurer's agent] to continue the interim coverage and to obtain from the respondent an application. Misrepresentation and non-disclosure in written application cannot avoid insurance antecedent to it and not granted upon the faith of it.

The insured was successful on the grounds that notice of rejection by the insurer to its agent was not a notice to the insured and the agent in receiving such a notice was not the agent of insured. However, the position of the insurer was prejudiced because the agent deliberately withheld the information about the misrepresentation from the insurer, and also failed to communicate the notice of rejection to the insured. Based on the reasoning that the application for insurance containing the misrepresentation was not the basis of interim coverage, the Appellate Court's finding against the insurer was justified. It is submitted that the case should have been decided against the insurer on the ground that the agent, in soliciting insurance, is regarded as the agent of the insurer, thereby reversing the Newsholme rule. This will be discussed in some detail later in this chapter.

(v) Surrender of policy before accident; effect on victims

Where the insurer requests the surrender of the policy and the insured complies before the accident and accepts the return of full premiums, the right of any third party accident victims to recover indemnity is forfeited because there is no valid insurance in force. In that event, the defence of misrepresentation in the application for insurance is unnecessary. This is evident from the case of Ellis v. London-Canada Insurance Co., ${ }^{366}$ decided by the Supreme Court of Canada. The insured in this case had untruthfully represented, to the knowledge of the agent who signed the application which was later ratified by the insured, that there was no refusal of previous automobile insurance and suspension of license. On instructions from the insurer that the risk was undesirable, the agent wrote the insured requesting the surrender of the policy. The insured immediately returned the policy without insisting on the fifteen days statutory notice required for unilateral cancellation, and received the refund of the premium and cashed the cheque before the date of the accident. In an action on the accident, judgement was recovered against the owner and then action was brought against the insurer.

Statutory condition 12, pursuant to section 197 of the Ontario Insurance Act, ${ }^{367}$ provides:

12.-(1) The policy may be cancelled at any time at the request of the insured named therein, and the insurer shall, upon surrender of the policy, refund the excess of paid premium above the customary short rate premium for the time the policy has been in force.

(2) This policy may be cancelled at any time by the insurer giving to the insured named in the policy fifteen days notice in writing of cancellation by registered post, whether registered within or without Canada, or five days notice of cancellation personally delivered, and refunding the excess of paid premium beyond the pro rata premium for the expired time. Repayment of excess premiums may be made by money, post office order, postal note or cheque. Such repayment shall accompany the notice and in such case the fifteen days

${ }^{366}$ [1954] S.C.R. 28, [1954] 1 D.L.R. 785, [1954] I.L.R. 1-14 at 581, affirming [1953] 1 D.L.R. 607, [1953] O.R. 141, [1953] I.L.R. 500, which rev'd. [1952] 4 D.L.R. 316, [1952] O.R. 644, [1952 I.L.R. 411.

367 R.S.O. 1950 , c. 183. 
above-mentioned shall commence to run from the day following the receipt of the registered letter at the post office to which it is addressed.

The Ontario High Court of Justice granted judgement in favour of the plaintiff on the ground that, by cancelling the policy, the insurer recognized that the contract existed and incurred the risk involved in statutory condition $12(2)$ requiring notice ${ }^{368}$ Appeal to the Ontario Court of Appeal was allowed. The plaintiff then appealed to the Supreme Court of Canada. With regards to the invocation of statutory condition 12 , Taschereau J., in a majority judgement, remarked:369

The Statutory Condition applies in case of unilateral cancellation, but does not prohibit a cancellation of a policy by mutual agreement, and here this agreement was prior to the accident... If Gillan [the insured] had refused to comply with the request of the company which was his undisputable right, the company then could have in. voked section 197, Statutory Condition 12(2), and the policy would have remained in force for fifteen days.

There appears to be great force in the argument advanced by McRuer, Chief Justice of the Ontario High Court, that the defendant, by giving notice of cancellation, was treating the contract as subsisting and trying to avoid any future contingent liability, instead of repudiating the insurance contract on the basis of misrepresentation. ${ }^{370}$ The insurer knew about its obligation to give statutory notice whereas the insured did not. It is for the courts to protect the interest of the insured and third parties where the insurer attempts to take advantage of the lack of knowledge on the part of the insured as to his legal rights. Unless the courts can find dishonest conduct on the part of the insured, indemnity under the policy should not be denied him.

\section{Non-disclosure and/or misrepresentation}

Cases where the courts have not distinguished between non-disclosure and misrepresentation, or where they have held that a non-disclosure amounted to misrepresentation will now be briefly analyzed.

\section{(a) Driving convictions}

In Hoey v. Merit Insurance Co., ${ }^{371}$ the plaintiff obtained a policy of automobile insurance through the services of the dealership from which he had bought and financed a car. The plaintiff failed to disclose in the application for insurance repeated convictions on charges of impaired and dangerous driving and license suspensions. The plaintiff was involved in a head-on collision and the car was totally demolished. The insured demanded the full value of the automobile but the insurer denied liability completely, alleging non-disclosure as discussed above.

The plaintiff admitted that he had read the application and confirmed its accuracy, but alleged that there was not sufficient space on the application to record the answers. In response to three questions which required a simple "yes" or "no" answer, the plaintiff penned them with a dash. Wilson J., of the Manitoba Queen's Bench, commenting on the effect of such an answer said: "Significance of the 'answer' so penned, i.e., a dash, I find equivalent to a negative, or 'not applicable' response." 372

368 [1952] L.L.R. $1-077$ at 315.

369 Supre, n. 366 [1954] I.L.R. 1-141 at 583.

370 Supra, n. 368.

37 [1971] I.L.R. $1-417$ at 1274.

372 Id. at 1276. 
In quoting Maybank J., of the Manitoba Queen's Bench, in Valgardson v. Contingency Ins. Co.,373 the judge pointed out that "by using the word 'knowingly' the Act rules out innocent misrepresentation, or innocent failure to disclose; further, the onus is on the defendant, not only to prove misrepresentation but also to prove knowledge."374

Wilson $\mathrm{J}$. found that the plaintiff had failed to disclose facts required to be stated in the application which were material for the consideration of the risk, and that such non-disclosure amounting to misrepresentation was done "knowingly". 375

The decision in the case regarding the significance of the "dash" answer must be contrasted with cases where it has been held that the insurer, by accepting the risk without requiring a reply to questions unanswered, has waived the question as if it was not printed in the application. ${ }^{376}$ The approach of the Manitoba court in the present case is in conformity with the English cases ${ }^{377}$ and Hanson v. Queensland Ins. Co., ${ }^{378}$ decided by the Supreme Court of Alberta, but does not seem to be reasonable inasmuch as the insurer is allowed to benefit by its own failure in not requiring the insured to supply answers to all the questions in the proposal form before accepting the risk. It is not suggested that where the insured has been guilty of deliberate nondisclosure or misrepresentation he should recover under the policy. The insurer should rather insist that all questions be answered, and then if the insured "knowingly" misrepresents or fails to disclose any material fact required to be stated, the right of recovery under the policy may be forfeited.

It is, however, suggested that insurers be placed under a statutory obligation not to accept an application for insurance unless all the questions in the application have been answered. The enactment should also provide that notwithstanding this provision, if an insurer elects to accept an application with a dash or blank answer, it shall be deemed to have waived the question and no defence based on such a non-disclosure will be sustained.

\section{(b) Cancellation of policy for non-disclosure following loss}

In Wells v. General Exchange Ins. Corp.,379 the plaintiff insured a truck with the defendants that was subsequently destroyed by fire. The insurer contended that the insured had failed to disclose an impairment in one leg and three accidents in which he was involved during the past three years. The policy sued on was cancelled following the loss and the full premium, which was returned by the insurer, was retained by the insured who also sent back the policy. Later the action was brought against the company.

The medical evidence established that there was no impairment as alleged. The trial court accepted the explanation given by the plaintiff that in his view "since he was not damaged in respect of the cars that

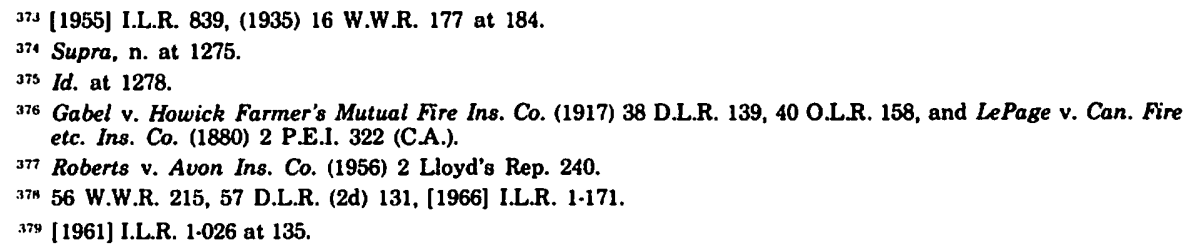


ran into him from the rear and that no vehicle was involved when he slid off the road that he had not therefore been in an accident."380

On appeal to the British Columbia Court of Appeal, Bird J.A., accepting the findings of the trial judge, said: ${ }^{381}$

... the respondent thereby did not 'knowingly misrepresent' or knowingly 'fail to disclose' those facts ... since the policy of insurance was shown to have been in full force and effect at the date of loss by fire ... the attempted cancellation of the policy by the appellant after the date of the fire was not an effective cancellation ... the policy was returned to the company's agent without conceding the validity of the position taken by the company.

The case must be distinguished from Ellis v. London-Canada Insurance Company, discussed above, ${ }^{382}$ where the insured had voluntarily surrendered the policy before the date of the accident and the policy was, therefore, not subsisting at the time of the mishap. The same results could have been achieved in Ellis if the insured had insisted on his statutory rights, or the court had held that the insurer by not giving the required notice had prejudiced the rights of the insured and third parties. Such a finding is necessary and reasonable in view of the interest of innocent third parties who are at the mercy of misrepresentations made by the insured.

\section{Disclosure through insurance agents}

It is not very common for the proposed assured to apply for insurance coverage directly to the insurer. Rather, insurance companies employ a number of agents to solicit insurance business for them and to collect premiums. ${ }^{383}$. The agent or broker is, therefore, a principal participant in the making of insurance contracts. He is also in a position to mitigate or aggrevate the conditions surrounding dispustes between the insured and the insurer. ${ }^{384}$ The discussion of the case law on non-disclosure and misrepresentation would, therefore, be incomplete without a discussion of the agency function.

The agent, in soliciting insurance business, acts for both parties simultaneously, i.e., for the proposed insured and the insurer. The agent acts for the insurer in soliciting insurance business, collecting premiums, issuing receipts, receiving notice of changes material to the risk and delivering policies. He often acts as well for the consumer of insurance because the latter normally seeks his advice and may ask or allow him to complete the proposal form. This is a consequence of the applicant's belief that the agent is equipped with a knowledge of insurance matters and can complete the application in a manner most satisfactory to the insurer. The agent has a manifest interest in completing the application and procuring the policy because he earns commission on the business procured. This places him in a conflict of interest situation.

It is possible for the proposal form completed by the agent to include a misrepresentation or non-disclosure of material facts. It then becomes necessary to determine whether the agent, in completing the application form, was acting as the representative of the insured, of the insurer, or of both.

\footnotetext{
$3+1 d$. at 136.

381 Id. at 137 .

382 Supra, n. 266, 366.

363 Colinvaux, The Law of Insurance 224 (3d ed. 1970).

so4 Shibley, Law Society of Upper Canada Lectures 241 (1962).
} 
The position of a broker should first be briefly examined. A broker, in placing insurance, is considered an agent of the insured only. Under the common law, a broker cannot accept employment from another principal inconsistent with his duty to the first principal unless he fully discloses his interest to both principals and obtains their consent. ${ }^{385}$ There cannot, therefore, be a clash of interest unless permitted by both principals. This is not the case with an insurance agent.

\section{Classes of agents}

There are several different classes of agents each with varied powers to bind the insurer. Therefore, it is necessary to discuss the classes of agents and the extent of their authority to commit insurers to binding contracts. It may be noted that only certain classes of agents are candidates for "apparent authority" and that not every agent, by his acts or omissions, can bind the insurer.

The decision in Potvin v. Glen Falls Ins. Co., ${ }^{386}$ although somewhat dated, contains a good discussion of the classes of agents. The case also makes it clear that a "soliciting agent" has no authority to bind the insurer. In that case, the application for fire insurance was filled out by one Martin, the soliciting agent of the insurer, and signed by the plaintiff. The application was sent to the general agents of the company, but Martin told the plaintiff that the insurance began to take effect from "today". The application was rejected by the general agents within five days of its execution. The property, the subject of insurance, was, however, destroyed in the intervening period.

The evidence established that Martin was a non-recording agent who was not supplied with any interim or renewal receipts and had no authority to grant oral or other cover. He was authorized only to solicit applications which were scrutinized by the general agents of the company and were either accepted or returned to Martin.

Ford J., of the Alberta Supreme Court, found that the soliciting agent had no authority to bind the insurer. The judge laid down the following legal classification of insurance agents:

(1) General Agents for a province: They are empowered to issue policies of insurance, interim receipts and to grant oral coverage on behalf of insurers.

(2) Recording Agents: They possess the same power as the General Agents.

(3) Non-recording Agents who are authorized to issue interim receipts. They can grant interim coverage either orally or in writing.

(4) Non-recording Agents who are not issued interim receipts but are provided with proposal forms. These agents cannot grant interim coverage either orally or in writing. These are also called "Soliciting Agents".

Ford J., citing judicial precedents with reference to implied authority, remarked:387

$\ldots$ in all the cases in which it has been held that an agent of an insurance company had implied authority to bind the company the agent either had in his possession some indicia of authority, some forms to implement his promise of an interim covering, or the course of the dealing between the agent and his principal showed that with the

\footnotetext{
${ }^{385}$ Anglo-African Merchants, Ltd. and Exmouth Clothing Co. v. Bayley [1969] 1 Lloyd's Rep. 268.

385 [1931] 1 W.W.R. 380.

347 Id. at 390.
} 
knowledge and consent of his superiors he had been habitually exercising the authority he assumed.

It was suggested by Ford J., that where the agent is entrusted with interim receipts, renewal certificates, blank policies duly signed by the directors of the company or completely executed policies for delivery against payment of premium, he may have apparent authority to bind the company. It is, however, pointed out that there can be other instances of implied authority; for example, a "pink card" issued by an agent in the case of automobile insurance.

Ford J. required that the applicant for insurance make reasonable enquiry as to the authority of the agent with whom he was dealing and that he insist on an interim receipt if immediate cover were desired.

It is submitted that where the consumer of insurance is obliged to make his own enquiries, at his own risk, as to an agent's power to bind the insurer, that is to require more than what is reasonable.

A brief analysis of the case law in Canada and England on the extent of an agent's authority follows.

\section{Case law in Canada}

\section{(a) Agents with express or implied authority}

An insurer will be bound by all the acts or omissions of its agent if they fall within his express or implied authority. The knowledge of the agent as to the material facts will be treated as the knowledge of the company. The insurer may also be estopped from denying the liability where an act or omission of the agent is acquiesced in by the insurer.

In $M c C o y$ v. Alliance Ins. Co., ${ }^{388}$ the plaintiff purchased a house and intended to remove it to another location. The plaintiff asked the defendant's agent, a general agent of the company, to place fire insurance on the house and specifically told him that the house was to be covered for both locations and during transit. The application for fire insurance was later filled out by the agent and signed on the plaintiff's behalf. The agent described the house as situated at the original location. A policy was issued covering the house on these premises. Later the agent erroneously assumed that the house had been moved to the new location and informed the insurer about it. An endorsement was issued covering this change. The house was later destroyed by fire while in transit. The policy containing the endorsement was with the defendant's agent until after the fire and the plaintiff could not, therefore, know that the contract did not cover the house while in transit. Following a loss, an action was brought against the insurer to recover indemnity and in the alternative against the agent for failing to secure proper insurance.

On the evidence, Treleaven J., of the Ontario High Court, found that the agent was the general agent of the company with authority to issue policies. The agency contract evidencing this fact was produced in court. The learned judge also observed that the house was identified and that the policy did not restrict the coverage to the house while on the named premises. He found, therefore, that the real contract was to insure the house on both locations and while in transit. As to the knowledge of the agent being the knowledge of the insurer, the judge make the following remarks: ${ }^{389}$ 
It is quite clear that the company knew, through its agent, that the house was to be moved, and if it did not intend to cover the house while in transit, it should have excluded it by some words of limitation from the policy.

Judgement was awarded against the insurer but the claim against the agent was dismissed. Since the knowledge of the agent was treated as the knowledge of the insurer, the insured did not suffer the consequences of failure on the part of the agent to communicate the material facts to the insurer.

An insurer will also be estopped from denying liability where it acquiesces in the transaction carried out by its agent. In Parise v. Canada Security Ass. Co., ${ }^{390}$ discussed in detail above, ${ }^{391}$ the defendant's agent, a recording agent of the company, knew that the car proposed to be insured was purchased in the name of the deceased's father who had executed a chattel mortgage to facilitate its financing. The agent issued endorsements to the policy orginally held by the son in respect of a previous car. The endorsement provided coverage in respect of the substituted car in the deceased's father's name and also insured the chattel mortgage. The son, while driving the car, was killed in an accident which resulted in liability to third parties. Judgement having been recovered against the estate of the deceased, an action to satisfy the judgement was brought against the insurer, who pleaded that the father was the sole insured. Moorhouse J., of the Ontario High Court, held the insurer liable for the following reasons: ${ }^{392}$

In view of the manner in which this transaction was carried out by the company's agent and acquiesced in by the insurer the suggestion of the plaintiff that the insurer intended to insure both the father and the son is entitled to prevail. The endorsements nowhere indicate clearly the son is no longer insured and protected. He was an insured in the policy....

The learned judge found that the deceased's father had an insurable interest in the vehicle since he was liable on the chattel mortgage to the bank and that the son was driving the vehicle with the permission of the father. Citing the $M c C o y$ case, supra, the judge said, "... the insurer, if not aware of all the facts, had such notice of them as to give no cause to now complain." 393

The case shows that where a transaction is carried out by the authorized agent of the company in such a manner as to give the insured a sense of security and is acquiesced in by the insurer, the latter will be responsible for any claim arising under the insurance coverage. Moreover, where the agent has actual authority to bind the company, notice to or knowledge of material facts possessed by the agent, is treated as notice to or knowledge of the insurer.

A consumer of insurance, without the agency contract or the cooperation of the parties, never knows what authority, express or implied, an agent has. Most often the consumer must rely on "appearances", i.e., apparent authority. The determination of apparent authority is a question of fact depending upon the circumstances in each case.

(b) Agents with apparent authority

An insurer will be held liable for the acts of its agent if it holds him out as its agent or allows the agent to hold himself out as its represen-

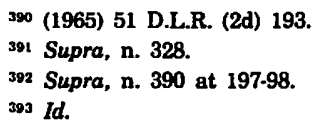


tative. This will also be so in cases where the agent has exceeded his actual authority.

In World Marine \& Gen. Ins. Co. v. Leger, 394 the plaintiff had applied for fire insurance coverage on his portable sawmill through the defendant's soliciting agent who was appointed as a sub-agent under the agency of Anderson \& Co., but with no writing in that behalf. The plaintiff signed an application form which was not addressed to any particular insurance company. No policy of insurance was issued, but the plaintiff had paid the sub-agent for the premiums. The sub-agent issued an ordinary receipt, though not on the company's form, acknowledging that he had received the premium. The sub-agent before accepting the premium had contacted Anderson \& Co., the general agents, about the acceptance of the risk. They advised him that they would try to place the insurance as the risk was to be brokered out. The sub-agent told the plaintiff that fire risks on portable sawmill "were very hard to place and would have to be brokered out." The day following this, the mill was destroyed by fire and the plaintiff brought an action alleging verbal contract.

The sub-agent was not supplied with any interim receipts or renewal applications to indicate that any authority had been conferred upon him. He had, however, in many cases received premiums. He could solicit applications for insurance but had no express authority to bind the company. The trial judge found for the insurer on the ground that an agent cannot bind his principal unless the former has express or implied authority to commit the latter. On the basis of evidence, the trial judge found that the sub-agent had no such authority.

This was reversed on appeal to the New Brunswick Supreme Court, Appellate Division, on the ground that the sub-agent was allowed by the general agents of the company to act as if he had authority to solicit applications for insurance and to collect premiums. According to the Appellate Court, the plaintiff had relied on the apparent authority of the agent and the defendants were bound by the acts of the sub-agent within his apparent authority. On appeal, the Supreme Court of Canada, per Kerwin J., found for the insurer on the basis of the following statement of Ford J., of the Alberta Supreme Court in the Potvin case:395

$\ldots$ in all cases in which it has been held that an agent of an insurance company had implied authority to bind the company the agent either had in his possession some indicia of authority, some forms to implement his promise of an interim covering, or the course of dealing between the agent and his principal showed that with the knowledge and consent of his superiors he had been habitually exercising the authority he assumed.

Kerwin J., quoted McGillivray on Insurance Law, 396 that "acceptance of a premium by an agent who has no actual or apparent authority to contract, does not bind the company."397 The learned judge also quoted from the opinion of Sir John Romily M.R. in Linford v. Provincial Horse and Cattle Ins. Co.,"398 to the effect that the applicant had made "a proposal with a deposit which the company was entitled either to accept or reject, and the company never having accepted it, was not bound."399

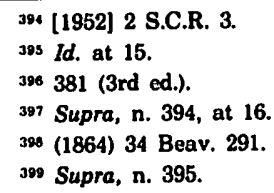


With due respect to this reasoning, it may be asked why insurance companies should be allowed to utilize premiums to their advantage, and also to reject the application if the loss happens in the meantime.

In such cases, insurers should be required by law to point out to the insuring public in their application forms that the agent is a soliciting agent and is not authorized to bind the company. In the absence of such a clear warning, insurers should be bound by the acts of their agents.

It may be noted, however, that any limitation on the authority of the agent to bind the company which is unknown to the third party is ineffective and the insurer will be bound by the acts of its agent provided they are within his apparent or ostensible authority.

In Berryere v. Fireman's Fund Ins. Co., and Murray, ${ }^{400}$ one Kariotis applied for liability insurance in respect of his motor vehicle through the defendant's agent, Murray, who told the proposer that because of his previous involvement in an accident, the application would have to be referred to, and approved by, the insurer. Before the application was accepted by the insurer, the proposer enquired about its approval and was informed by the agent that it had been granted. Thereafter, the agent issued the applicant with a "pink card", a financial responsibility card under the Manitoba Highway Traffic Act, 1954.401 The agent, by issuing the pink card and assuring Kariotis that he had coverage, purported to bind the company, although the insurer was not aware of these facts. The agent was much more than a mere soliciting agent and had authority to bind the company which was not in dispute, but the agent acted in disregard of specific instructions from the defendant in purporting to accept an application before the results of the referral were communicated to him. The applicant relied in good faith upon the results of the referral and the issue of the pink card. Before the application could be accepted by the insurer, Kariotis was involved in an accident resulting in liability to the plaintiff. Judgement having been recovered against Kariotis, action was brought against the insurer to have the insurance money applied toward the satisfaction of the judgement. It was contended on behalf of the defendant that the agent had no authority to communicate the results of the referral. The trial judge found for the plaintiff on the following grounds. 402

Murray was not a broker. He was defendant's agent, not Kariotis' [insured's]. Murray was much more than a mere soliciting agent. He had apparent or ostensible authority to bind [the insurer] ... With respect to third persons, limitations on the authority of an agent are ineffective if the acts of the agent are within his apparent authority and in the absence of knowledge by third persons .... Even if he [the applicant] had seen the agency contract and the underwriting instructions he would have known that Murray after referral could bind the defendant.

An appeal to the Manitoba Court of Appeal was not successful. Schultz J.A., on the basis of the evidence, found that the decision on the application of Kariotis was to be conveyed to the agent and not to the applicant. The agent could, therefore, bind the insurer by acceptance of the risk, or he could refuse it, according to the instructions received from the insurer. Since the agent was the only means of communication between the applicant and the insurer, the learned judge concluded:403

${ }^{100}$ [1964] I.L.R. 1-129 at 647 (Man. Q.B.).

01 R.S.M. 1954, c. 112.

${ }^{102}$ Supra, n. 400 . at 651.

${ }^{003}$ [1965] I.L.R. 1-134, 663 at 668 . 
... Murray [the agent] was held by the insurance company not merely as having authority to bind - that much was his apparent authority-but also quite ostensibly as having authority to communicate to Kariotis [the applicant] the result of the reference.

Regarding the argument of the defendant that the proposer should apply to the head office of the insurer to ascertain the acceptance or otherwise of the application, the learned judge remarked:404

... this could have readily been provided in the application form by a statement therein to that effect. But although, on the application form Kariotis was warned in vivid red ink of the consequences of false answers, there is nothing to indicate to him, or even to suggest, that his admission... [as to] a previous motor accident subtly changed his relationship with the company's agent; that he could no longer rely on such agent as the means of communication between the insurance company and himself, and that as far as the referral was concerned he must rely on the head office of the company.

The case represents good law inasmuch as the insured and the innocent victim were saved from the failure of the insurer in not warning the applicant about his limitation on the authority of the agent, i.e., that he had no authority to communicate the results of the referral. This approach has, however, not been consistently applied. The decision in Jensen v. South Trail Mobile Ltd., ${ }^{405}$ although not an insurance case, provides a contrast.

In that case, the plaintiff alleged that he had a contract with the defendants for the sale of one of their mobile homes in exchange for a similar home owned by him. The alleged deal was made through the agent of the defendant. The agent was the manager of the defendant company's dealership in the city of Whitehorse. The agent's authority was limited in that his letter of appointment provided "that all sales must have the final approval of Mr. Mandel or Fred Aitken [the company's officers] before considered being final." The agent had told the plaintiff about this limitation. Moreover, the purchase agreement provided that it is "[n]ot valid unless Signed and Accepted by an officer of the Company." When the plaintiff originally approached the agent for the result of the referral, he was informed that the trade-in was not accepted by the head office. The agent later advised him that he had finally received approval of the deal. It may be interposed here that, when a deal was approved, the practice of the company was to advise the agent over the telephone. A purchase agreement was executed by the plaintiff and the agent on a printed form supplied by the defendants. The agent, having taken delivery of Jenson's trailer, rented it to a third party and the alleged contract did not materialize.

An action was brought to enforce the alleged contract. The question to be decided was whether the representation to the plaintiff made by the agent of the company that the head office had finally approved the sale could bind the company. The trial judge, on the basis of the facts, concluded that the agent had been held out as having authority to make the deal. The trial judge quoted the law applied in the case of Reid \& Keast v. A. E. McKenzie Co. Ltd., ${ }^{406}$ as stated in Halsbury's Laws of England:407

429. Where a person has by words or conduct held out another person, or enabled another person to hold himself out, as having authority to act on his behalf, he is

40. Id. at 669.

${ }^{405}$ [1972] 28 D.L.R. (3d) 233.

105 (1921) 61 D.L.R. 95 at 97.

so7 1 Halbury's Laws of England 201 (1st ed.). 
bound, as regards third parties, by the acts of such other person to the same extent as he would have been bound if such other person had in fact had the authority which he was held as having.

The following exception to the principle was, however, quoted by the trial judge from Halsbury's:408

431. Where a principal, in conferring authority upon his agent to act on his behalf, imposes conditions or limitations on its exercise, no act done by the agent in excess of the conditional or limited authority is binding on the principal as regards such persons as have or ought to have notice of such excess of authority.

But in the absence of notice, the principal cannot by any instruction to his agent, escape liability for acts done by the agent which fall within the apparent scope of his authority.

The trial judge concluded that the case did not fall within the ambit or purview of the exceptions and gave judgement for the plaintiff. On appeal to the Alberta Supreme Court, Appellate Division, the case was decided against the plaintiff. Clement J.A., of the Appellate Division, found that the plaintiff knew of the limitation on the agent's authority, and that the agent was not an officer of the company authorized to execute a contract binding on the company. The judge made the following remarks:409

There is no evidence that the company held out to Jensen in any way, whether by act or omission, verbally or in writing, that the known limitation on Kozmeniuk's [agent's] authority had been modified; rather, it is clear that Jensen understood at all times that the limitation existed.

The following dissenting opinion of McDermid J., of the Alberta Supreme Court is worthy of attention: 410

As the source of the knowledge of the limitation was the Agent, I think Jensen was justified in accepting from the same source the representation that approval had been obtained. It was the practice of the Company to approve any transaction by telephone to the Agent. The Company did not expect the customer to communicate with them. They relied on their Agent and, in my opinion, Jensen was entitled to rely on him also and accept his assurance that the sale had obtained the requisite approval.

The dissenting opinion is to be preferred because the defendant itself did not take sufficient steps to point out the limitation to the customers and left the matter entirely in the hands of their agent. Since the source of limitation was the agent, a customer would be justified in believing the representation by the agent that the required approval had been granted by the head office of the company. This is the reasoning of the Berryere 411 case. Since the result of the referral in this case was to be communicated through the agent, as in Berryere, the court should have similarly held that the applicant could rely on the presentation of the agent that the risk had been approved. The majority decision in Jensen does not augur well for the insuring public in Alberta. It means that the customer who relies upon the agent's advice may do so at his own risk.

When an agent, in purporting to bind the insurer, exceeds his actual authority, but his acts are within his ostensible authority, the insurer may be bound by those acts and liable to the insured. In Buske v. Potter and London \& Midland Gen. Ins. Co., ${ }^{412}$ the plaintiff had applied for

\footnotetext{
${ }_{100}$ Id.

${ }^{409}$ Supra, n. 405. at 242.

$410 \mathrm{Id}$. at 237.

(11 Supra, n. 400.

12 (1965) 54 D.L.R. (2d) 290.
} 
motor vehicle insurance in respect of legal liability and physical damage to the car through the defendant's agent, Potter. The period of coverage was stated to be six months. The agent was supplied with application forms and rates book but was not authorized to issue certificates of insurance. The agent accepted the premium and issued a receipt therefor, indicating that the risk was covered effective July 7,1974 . The agent, exceeding his actual authority, also issued a certificate of insurance which provided coverage from July 7, 1964, to January 7, 1965. The application for insurance was forwarded to the head office of the company for approval. The insurer later, on July 24, 1964, sent a notice of cancellation of the binder to the agent, but no communication was made to the plaintiff until after the accident. The company, in the meantime, had retained both the application form and the premium. Following a claim, the insurer denied that any contract of automobile insurance existed between it and the plaintiff as it contended that the binders were normally issued for fifteen days. Anderson $J$. found for the plaintiff on the following grounds: 413

In my view, John Potter [the agent] held himself out as the ostensible agent ... at least to the extent of having the right to issue insurance liability certificate that he did issue.... The defendant Potter may have exceeded his authority as far as his principal ... was concerned, but he did not exceed his ostensible authority in so far as the plaintiff was concerned when he issued the insurance certificate....

As regards the defence of the insurer that the certificate of insurance was customarily issued for fifteen days, the learned judge observed that this was irrelevant because it was in fact issued for six months. He also held that, in the absence of a cancellation notice, the plaintiff was entitled to assume that he was fully covered in respect of collisions. The insurer was estopped from denying the liability because:414

... when a premium of insurance has been received, together with an application form, its retention by the insurer, though perhaps not conclusive, raises a strong presumption, in the absence of circumstances leading to the contrary conclusions, that the in surer has accepted the proposal of the applicant.

The determination of ostensible authority is a question of fact in each case. The court rightly concluded that the agent had held himself out as the ostensible agent. Moreover, there was nothing in the application form or the certificate to suggest that the agent was not authorized to issue the certificate in question. It is suggested that the courts should lean in favour of finding ostensible authority to protect the legitimate interest of the insuring public, who must rely on the authority which the insurance agent appears to possess.

The insurer is liable for the acts of its agent falling within his apparent or ostensible authority, not only to the insured, but also to the collision victims.

In Code v. British America Ass. Co.,415 one McCastlin purchased a 1958 Vauxhall automobile from the plaintiff. McCastlin could not transfer the ownership of the vehicle as he was not insured. He approached the defendant's non-recording agent for insurance coverage. The agent had "full power and authority on behalf of the company to receive proposals for insurance, countersign and deliver binders, interim cover notes, renewal and other certificates, endorsements, permits and

413 Id. at 379,384 .

11. Id. at 299 .

41 (1972) 29 D.L.R. (3d) 264. 
policies. ..." No application for insurance was made, no premium paid and no policy was issued. The defendant's agent, over-stepping his express authority, issued an insurance liability certificate which was used in transferring the ownership to McCastlin.

At the time of the accident, McCastlin was driving a 1953 Volkswagen borrowed from the plaintiff since his car was undergoing repairs. As a result of the accident, the occupants of the other car were injured and recovered judgement against the plaintiff, the owner of the vehicle and the estate of McCastlin, since the latter had in the meantime died. The accident in question was never reported to McCastlin's insurer. The plaintiff was insured with another insurer and paid off the judgement against himself to the victims. The plaintiff, being unable to recover from the estate of McCastlin, brought an action against the defendant, McCastlin's insurer.

The issue was whether the liability certificate could be relied on as evidence of insurance coverage. Lieff J., of the Ontario High Court, cited the cases of Berryere v. Fireman's Fund Ins. Co., and Murray, ${ }^{16}$ and Wassink v. Western Union Ins. Co. ${ }^{417}$ dealing with apparent or ostensible authority. In the Wassink case the plaintiff was issued a pink card by the agent of the insurer. No proposal was made and no policy was issued. The pink card bore a policy number but no policy was in fact issued. In the words of Lieff J., of the Ontario High Court, it was held in the Wassink case: ${ }^{418}$

... that an agent having apparent or ostensible authority will bind his principal by acts done within the scope of such authority even though, unknown to the person dealing with the agent, the acts extended beyond limits imposed by the principal.

In the Code 419 case, Lieff $\mathrm{J}$., found that the agent, by issuing a liability certificate to McCastlin, had demonstrated that he could bind the insurer. McCastlin was, therefore, entitled to rely on the representations of the agent. The plaintiff was, therefore, indemnified in respect of amounts already paid by him to the victims.

The case makes it clear that where an agent exceeds his actual authority, but acts within the scope of his ostensible or apparent authority and issues a liability certificate, the insurer is liable not only to the insured, but also to the third parties who after recovering judgement seek to enforce it against the insurer.

It may be noted that holding out is a form of estoppel, and, if the agent is held out as having authority to bind the company, any waiver of warranty by the agent will estop the insurer from disclaiming liability.

In Fallas v. Continental Ins. Co.,420 the plaintiff applied for marine insurance coverage through the defendant's agent in respect of physical damage to or loss of his boat. The application for insurance filled out by the agent was sent to the insurer without the signature of the plaintiff. The defendant did not require the plaintiff to sign the application. The policy issued to the plaintiff bore the counter-signature of the agent. The policy contained a clause warranting that the insured would not operate

\footnotetext{
41 Supra, n. 400.

11 (1964) 49 W.W.R. 404.

118 Supra, n. 415 at 273.

119 Id.

420 [1973] I.L.R. 1.558 at 1848 .
} 
the boat outside the designated trading limits. The plaintiff made frank disclosure to the agent that he wished to operate the boat outside the policy trading limits. The agent said that that would be all right. The defendant was neither informed nor aware of this arrangement between its agent and the plaintiff. The boat, while being operated outside the trading limits, became a total loss and the plaintiff lodged a claim therefor.

The defendant denied liability on the ground that the plaintiff had committed a breach of warranty by navigating the vessel outside the trading limits. The question to be determined was whether the waiver of warranty by the agent was a holding out which could estop the company from denying liability. Berger J., of the Supreme Court of British Columbia, had this to say on the matter: ${ }^{421}$

There was a holding out by the defendant. Mr. Fallas [the insured] was led to believe that Mr. McGaw [the agent] had the power to waive the warranty. The policy itself said that it was not valid 'unless countersigned by the duly Authorized Representative of the Company'... . Continental held out McGaw as its agent, not merely to solicit applications, but also to bind Continental and to waive the requirement relating to trading limits.

The judge found that the agent had sufficient indicia of authority in the power to countersign policies and the plaintiff was, therefore, entitled to rely on such authority.

It may be interposed here that the old English case of Bawden $\mathbf{v}$. London Edinburgh and Glasgow Assurance Co.,422 held that the knowledge of a soliciting agent as to material facts was the knowledge of the insurer. In that case, the plaintiff had only one eye, but failed to disclose it in the application. The agent knew about the disability but did not communicate it to the insurer. The Court of Appeal, therefore, found that there was a waiver of the requirement by the company, and that the knowledge acquired by the agent within the scope of his apparent authority ought to be imputed to the company. This case has, however, not been followed in Canada and is little followed in England. ${ }^{223}$ In Canada, the knowledge of a soliciting agent cannot be imputed to the insurer. According to Berger J.:424

The Supreme Court of Canada has held that the knowledge of a general agent or of an agent who has authority to bind the company estops the company from denying liability. Hastings Mutual Fire v. Shannon (1878) 2 S.C.R. 395; Mahomed v. Anchor Fire \& Marine Ins. Co. (1913) 48 S.C.R. 546, 15 D.L.R. 405.

As regards the waiver of warranty in the Fallas ${ }^{425}$ case, it has been noted previously that a waiver under the provincial Insurance Acts must be in writing duly signed by an authorized representative of the insurer. ${ }^{426}$ The above case was, however, governed by the British Columbia Marine Insurance Act ${ }^{427}$ which does not contain a similar provision.

The trend of the decisions shows that a soliciting agent cannot bind the insurer, ${ }^{428}$ but, where an agent has been held out as having authority,

421 Id. at 1851 .

122 (1892) 2 Q.B. 534.

12J Holdsworth v. Lancashire \& Yorkshire Ins. Co. (1907) 23 T.L.R. 521.

424 Supra, n. 420 . at 1850.

$42 \mathrm{~s}$ Id.

126 Insurance Act, R.S.A. 1970, c. 187, 8. 198.

427 R.S.B.C. 1960 , c. 231.

42" Potvin v. Glen Falls Ins. Co. [1931] 1 W.W.R. 380; World Marine \& Gen. Ins Cy. v. Leger [1952] 2 S.C.R. 3. 
the insurer will be bound by the acts of its agents, provided that they are within the scope of his apparent authority, ${ }^{429}$ although he may have exceeded his actual authority. ${ }^{430}$ The insurer will also be liable where he acquiesces in the transaction carried out by the agent. ${ }^{431}$ Where an insurer places a limitation on the authority of its agent, the insurer cannot escape liability unless the limitation was known to the insured. If the source of information about the limitation is the agent, the insured may be justified in believing that the agent has obtained the approval of the insurer. ${ }^{432}$ However, it has been held, to the contrary, that a third party cannot recover unless a known limitation was modified by the principal to the knowledge of the third party. ${ }^{433}$

In view of the lack of knowledge on the part of the insuring public as to the classes of agent, their authority to bind the company, limitations on their powers, and the fact that the agent acts for the insurers and is remunerated by them, insurers should be bound by the acts of their agents irrespective of their classification and the delegation of authority. The consumer of insurance should not be under an obligation to make enquiries at his own risk as to an agent's power to bind the company. Moreover, distinctions between recording and non-recording agents regarding their powers to bind insurers are outdated and of little relevance to the insuring public.

\section{Case law in England}

\section{(a) Agents with apparent or ostensible authority}

In England, as in Canada, if an insurer holds out another person as his agent it will be bound by the acts of such person, provided that they fall within the scope of his apparent authority. It is of no relevance that the agent has exceeded his authority, and any legal defence by the insurer based on such excess of authority may not be admissible.

In Holdsworth v. Lancashire \& Yorkshire Ins. Co.,434 the plaintiff had effected workmen's compensation insurance with the defendants. The proposal was filled out by the agent of the company and signed by the plaintiff. At the time of application, the agent knew that the plaintiff was a joiner and builder, but described him in the application only as a joiner. A policy was later issued with this description. This was objected to by the plaintiff. The agent, with the permission of Chief Clerk of the insurer, altered the policy by inserting the word "builder" after the word "joiner". This was not communicated to the insurer. The plaintiff, however, paid a number of premiums on the faith of the policies continuing valid and effectual. Following a claim on one of the renewals of the policy, the insurer denied liability.

Bray J., of the King's Bench Division, found that the insurer, by receiving continued payments of premium, was precluded from denying the agent's authority to alter the contract. In view of the knowledge possessed by the agent that the plaintiff was a "joiner \& builder", the

\footnotetext{
429 McCoy v. Alliance Ins. Co. [1951] 2 D.L.R. 296; Fallas v. Continental Ins. Co. [1973] I.L.R. 1-558 at 1848.

430 Buske v. Potter and London \& Midland Gen. Ins. Co. (1965) 54 D.L.R. (2d) 290; Code v. British America Ass. Co. (1972) 29 D.L.R. (3d) 264.

431 Parise v. Canada Security Ass. Co. (1965) 51 D.L.R. (2d) 193.

${ }^{432}$ Berryere v. Fireman's Fund Ins. Co., and Murray [1964] I.L.R. 1.129.

433 Jensen v. South Trail Mobile Ltd. (1972) 28 D.L.R. (3d) 233.

434 (1907) 23 T.L.R. 521.
} 
learned judge found that the agent's knowledge was the knowledge of the company. The judge had this to say on the matter.435

The contract must be treated as negotiated with a joiner and builder, and not with a joiner only, and in that sense the knowledge of the agent was the knowledge of the company ...., even if there had been no alteration at all in the policy, Holdsworth [the insured] would have been entitled to recover and the fact that an alteration had been made could not in any way prejudice Holdsworth's claim.

The case of Bawden v. London Edinburgh and Glasgow Assurance Co., ${ }^{436}$ was followed. In the Holdsworth case, the inaccuracy in the proposal was made by the agent and, as in the Bawden case, knowledge of the facts possessed by the agent was treated as knowledge of the company.

A similar approach in Canadian courts would be desirable in such cases.

Receipt of premiums by an agent does not necessarily bind the insurer, but, in particular circumstances, where the agent has been customarily receiving premiums on behalf of the insurer, he may bind the insurer if he has received payment thereof after becoming aware that the insured has breached a condition affecting the validity of the policy. The insurer in such circumstances may be estopped from denying the liability.

In Wing v. Harvey, 437 the life policy issued to the deceased provided that it would become void and the insurance money forfeited if the insured should go beyond the limits of Europe without the permission of the Society's directors. The insured came to Canada but continued to regularly remit the premiums to the Society's agent at the place where the policy was effected. The agent knew about the breach of the condition, but represented to the insured that it did not invalidate the policy provided that the premiums were not in arrears. The insured died in Canada. Following a claim, the Society denied liability. An action brought against one of the directors of the Society was tried by the Court of Appeal in Chancery. The headnote reads:438

... the insurance company must be considered to have received constructive notice of the breach of condition, express notice having been given to their agent; and that, whether the company had express notice of the breach or not, the conduct of their agent had been such as that, at the death of the insured, the policy ought to be considered as valid and subsisting.

The defendant was properly prevented from denying liability because of the constructive notice of breach of condition and the conduct of the agent in receiving the premiums and transmitting them to the Society. The agent was, therefore, held out as having the authority to waive the condition of the policy.

Where an agent acts beyond his actual authority, the insurer can repudiate the act, provided that it acts promptly and the position of the insured has not been prejudiced.

In MacKie v. European Ass. Society, ${ }^{439}$ the plaintiff had applied for fire insurance on its mill and warehouse through the defendant's agent,

435 Id. at 524.

436 (1892) 2 Q.B. 534.

37 (1854) 5 De G.M. \& G. 265, 23 L.T.O.S. 120.

438 Id. 23 L.T.O.S. 120.

439 (1869) 21 L.T.R. 102. 
who was also the agent for Commercial Union Ass. Co. The plaintiff had carried insurance in the past with Commercial Union, but at the time of the new application for insurance he did not know that the agent had ceased to represent Commercial Union. The agent received a deposit of premium from the plaintiff, and issued a receipt therefor which provided that "[d]uring the interim the assurance remains in legal force." The plaintiff, on learning that the printed form of receipt was on behalf of the defendant, wrote a letter to the agent stating that he would like to be satisfied as to the standing of the defendant before consenting to the payment of the entire premium. The plaintiff did not hear anything as to the acceptance or rejection of the risk. Before the issue of the policy, a part of the premises was burnt down by fire. Following a claim, the defendant denied liability on the ground that the plaintiff had repudiated the contract by his letter to the agent. Moreover, the defendant contended that the agent, by not communicating the interim assurance, had miscarried the authority.

The evidence established that the agent had authority to accept or reject risks as he considered desirable, and that not a single proposal forwarded by him to the defendant was rejected. As regards the repudiation of the contract by the plaintiff, Malins V.C. remarked that the intention of the plaintiff was not to remain uninsured. With respect to the excess of authority, the learned Vice Chancellor observed:40

The agent binds the company, and they can repudiate [interim insurance] if he exceeds his limit before the event [loss] happens and afterwards it is too late to set up the defence.

It follows, therefore, that if the agent acts beyond the scope of his actual authority but within apparent authority and the insurer fails to repudiate the contract before a loss occurs, the insurer will be estopped from denying liability. ${ }^{441}$

In summary, the jurisprudence on an agent's apparent authority in Canada and England is to the same effect in that where an insurer holds out a person as its agent, it is liable for all the acts of the latter performed within the scope of his ostensible authority.

It is submitted that the rule regarding an agent's mis-statement or non-disclosure of material facts in the insurance application should be that the agent, in filling out the proposal form, is the agent of the insurer for all purposes of disclosure, whatever be the class or category of agent involved. The agent's knowledge should be imputed to his principal, the insurer.

\section{Statutory regulation of agents}

Section 504 of the Alberta Insurance Act, ${ }^{442}$ a general provision, which deals with the function of the agents in collecting premiums provides:

(1) An agent or broker shall, for the purpose of receiving any premium for a contract of insurance, be deemed to be the agent of the insurer notwithstanding any conditions or stipulations to the contrary.

Section 237 of the Alberta Insurance Act, ${ }^{443}$ dealing with life insurance contracts provides:

140 Id. at 105 .

141 Kelly v. London and Staffordshire Fire Ins. Co. (1883) Cab \& El., 47; Brocklebank v. Surgue (1831) 5 C. \& P. 21.

412 Supra, n. 51.

143 Id. 
(1) Subject to any provisions to the contrary in the application or the policy, a contract does not take effect unless

(b) payment of the first premium is made to the insurer or its authorized agent.

Statutory condition 4 enacted under section 223 of the Alberta Insurance Act,444 which deals with fire insurance, provides that "any change material to the risk... [be] promptly notified in writing to the insurer or its local agent...." Similarly in automobile insurance, statutory condition 1 under section 288 of the Alberta Insurance Act 45 stipulates that " $[t]$ he insured . . . shall promptly notify the insurer or its local agent in writing of any change in the risk material to the contract...."

Similar legislation exists in other provinces. ${ }^{446}$

The Insirance Acts of the Provinces of Alberta, British Columbia, Manitoba and Ontario are silent as to the effect of misrepresentation or non-disclosure in an application for insurance completed by the agent. It may be interesting to note that the Legislature of Quebec has taken an enlightened step in stipulating in its Insurance Act that where the application is completed by the company's agent, this shall be deemed an act of the insurer. Statutory condition No. 1 enacted under section 240 of the Quebec Insurance Act, 1964,447 relating to fire insurance provides:

If any person insures his buildings or goods and causes the same to be described otherwise than as they really are, to the prejudice of the company, or misrepresents or omits to communicate any circumstance which is material to be made known to the company, in order to enable it to judge of the risk it undertakes, such insurance shall be of no force with respect to the property in regard to which the misrepresentation or omission is made; but when the application is made out by the company's agent, such application shall be deemed to be the act of the company.

This provision has the happy effect that an applicant does not suffer the consequences of misrepresentation or non-disclosure by the agent when completing the proposal form. ${ }^{448}$

It is submitted that this provision is desirable inasmuch as it protects the legitimate interest of the insuring public. Similar provisions should be instituted in other provincial Insurance Acts.

\section{Imputed knowledge}

On the question of whether the agent, in completing the proposal form, acts as the representative of the insured or insurer two conflicting views have been advanced. Ivamy has put them thus:449

According to the first view which has been severely criticized, the knowledge of the agent acquired during the negotiations, is imputed to the insurers, and the policy is accordingly valid, whether there was an omission ${ }^{450}$ or mis-statement. ${ }^{451}$ According to the second view, the agent's knowledge is not imputed to the insurers and they are entitled to avoid the policy on the ground that the duty of disclosure had not been discharged.452

tos Id.

445 Id.

46 Insurance Acts: R.S.A. 1970, c. 187, s. 223(4), equivalent provisions: R.S.B.C. 1960, c. 197, s. 208(4); R.S.M. 1970 , c. I-40, 8. 142(4); R.S.O. 1970 , c. 224 , 8. $122(4)$; R.S.A. 1970 , c. 187 , s. $288(1)$, equivalent legislation: R.S.B.C. 1960 , c. 197 , s. $222(1)$; R.S.M. 1970 , c. I-40, 8. $237(1)(1)$; R.S.O. 1970 , c. 224. 8. 205(1).

47 R.S.Q. 1964, c. 295.

«s Union Insurance Co. of Paris v. Monette (1924) 38 Que. K.B. 309-11 [Application completed by insurer's agent and signed by the proposer, an illiterate person. The agent knowingly described the premises only as a boarding house when it was also used as a grocery store.]

449 Ivamy, General Principles of Insurance Law 495 (2d ed. 1970).

${ }^{450}$ Bawden v. London, Edinburgh and Glasgow Ass. Co. [1892] 2 Q.B. 534 (C.A.) (accident insurance).

t51 Brewster v. National Life Ins. Society (1892) 8 T.L.R. 648 (C.A.) (life insurance).

452 Biggar v. Rock Life Ass. Co. [1902] 1 K.B. 516 (accident insurance). 
In accordance with the first view, it has been held in England that where the insured was an illiterate person, had only one eye, and the proposal form for accident insurance completed by the agent omitted this fact, the knowledge is to be imputed to the company, provided that this was solely the fault of insurer's agent and there was no breach of duty of disclosure on the part of the insured.453

Conversely, the second view that the knowledge of true facts possessed by the insurer's agent is not to be imputed to the insurance company has been followed in England and Canada. It is based on the ground that the insurer, in determining the extent of the risk and its acceptability or otherwise, is guided by the disclosure made in the application for insurance. The insurers are, therefore, entitled to assume that whatever is stated in the application discloses not only the truth but the whole truth, and any knowledge possessed by the agent which is inconsistent with the disclosures made in the application is not to be imputed to the insurers. According to this view, the agent, in completing the application form, momentarily ceases to be the agent of the insurer.

A detailed statement of the law that has emerged as a result of the second view is to be found in Halsbury's Laws of England.454

\begin{abstract}
...., where the proposer himself signs the proposal form, as is usually insisted upon by insurers, by signing he adopts whatever answers the agent has inserted and makes them his own. This is clearly the case where he reads and approves the answers before signing: but the position is the same if he chooses to sign the proposal without reading them, or if he signs the form when it is blank, leaving it to the agent to insert the answers later. It is irrelevant to inquire how the inaccuracy arose; or whether the agent acted honestly or dishonestly; or whether the agent had forgotten or misunderstood the correct information he had been given; or whether the answers were a mere invention on the part of the agent; if the result is that inaccurate or inadequate information is given on material matters, or that a contractual stipulation as to accuracy or adequacy of any information given is broken, it is the proposer who has to suffer.
\end{abstract}

This has been epitomized in the "Newsholme rule" followed in Canada. The "rule" has not been reversed so far except in Quebec, although exceptions to the "rule" have been found in other provinces. The "rule" is entirely unsatisfactory inasmuch as it places the innocent insured at the mercy of the non-disclosure or misrepresentation of the agent in whom the former places entire reliance. The circumstances giving rise to the case of Newsholme Bros. v. Road Transport and General Ins. $C_{0.45}$ may now be briefly examined.

The plaintiffs made a proposal in January, 1927 for automobile insurance for their motor-bus. The application form in question was filled in by Willey, the insurer's agent, and signed by $\mathrm{H}$. Newsholme, a partner of the plaintiff firm. The proposal form contained a "basis clause" and the insured by subscribing his signature to the application form warranted the accuracy and bona fides of the answers written and that no information was withheld.

The motor-bus was involved in an accident. It sustained damage and the passengers suffered injuries. A claim therefor was rejected by the insurer who contended that the proposal form contained untrue answers and that the disclosure of true facts might have influenced the accep-

453 Supra, n. 451.

45 22 Halsbury's Laws 204-5, notes (i to s) (3d ed. Simonds 1958).

45. [1929] 2 K.B. 356 (C.A.). 
tance of the risk. Following a reference to an arbitrator, answers to the following questions were found to be false:

(7) Have you previously been insured for motor risk? If so, give name of company. Answer: Atlas. (8) Have any insurers at any time in respect of any motor vehicle: (a) declined your proposal, or cancelled or not invited renewal of your policy? Answer. No; (b) required increased premium or special conditions on renewal, or required you to carry the first amount of each loss? Answer. No. (14) State hereunder particulars of all claims made or accidents which have occurred in connection with any motor vehicles owned by you, or under your control, during the past two years, whether insured or not.

A schedule drawn up by the agent revealed four accidents over the preceding two years. The arbitrator did not determine what the true answers would have been but found that the answers as written were untrue in material respects. The arbitrator was, nevertheless, of the opinion that Newsholme had disclosed the true facts to the agent who, for unascertained reasons, did not write down the correct answers. As to the reasons for the incorrect answers, the arbitrator speculated:456

It must be either: (i) that he [the agent] unintentionally wrote untruths, because (a) he did not understand Newsholme's communication to him, or (b) forgot what he was told, or (c) did not understand the questions asked; or (ii) that he intentionally wrote down untrue facts to earn his commission.

As to the capacity of Willey, the agent, the arbitrator came to the finding that Willey was appointed in writing to work under the Agency Manager of the company and supplied with proposal forms to solicit insurance business and collect premiums. The arbitrator concluded that the insurer was liable for the claim as the latter, through its agent, had full knowledge of the true facts. This finding was, however, reversed by Rowlatt, the trial judge.

On appeal to the Court of Appeal, the celebrated rule was laid down by Scrutton L.J.457

... Willey [the agent] was writing the answers as the amanuensis of Newsholme, whose answers they were to be; and after Willey had written the answers, Newsholme signed the proposal, and must be taken to have promised the truth of what he signed. I do not understand how in receiving the information as to these answers, Willey can be taken to be anything else than the agent of the person whose answers they are to be, and must be taken to have written them and promised they were true.

As regards the knowledge of the agent concerning the falsity or otherwise of the answers written, Scrutton L.J. had this to say:458

If the answers are untrue and he [the agent] knows it, he is committing a fraud which prevents his knowledge being the knowledge of the insurance company. If the answers are untrue, but he does not know it, I do not understand how he has any knowledge which can be imputed to the insurance company.

Scrutton L.J. reached the conclusion that a person who signs a proposal form for insurance without reading it, cannot avoid the consequences of his negligence if he fails to detect the concealment or misrepresentation made by the agent. He cannot thereafter allege that the agent, in completing the application form, is the agent of the insurer. The case was, therefore, decided against the insured.

The above findings have proved most damaging to the interests of the insuring public. The rationale of the case finds its support from an out-

\footnotetext{
4s6 [1929] All E.R. 442 at 445.

457 Supra, n. 455 at 364 .

4so Id. at 375-76.
} 
dated philosophy that an agent is employed merely to solicit insurance business and procure proposals, and that he cannot bind the company. When the agent is supplied with stationery, proposal forms, rating book, authorized to collect premiums, issue receipts therefor, deliver policies and to receive notice of changes material to the risk, the insurer, by necessary implication, holds out the agent as empowered to bind the company. If the insurance companies want their agents to be merely soliciting agents with no authority to bind the company, they should not cloak their agents with all the trappings of authority to act. Moreover, they should be required to take the precaution of indicating to the applicant in the proposal forms that the agent has no authority to bind the company.

\section{Application of Newsholme rule in Canada}

In Rocco v. Northwestern National Ins. Co., 459 it was held that where an application for insurance is made through the general agent of the company who is authorized to issue policies, and the application, to the knowledge of the agent, contains material false statements knowingly made by the applicant, notice to or knowledge of the agent is not notice to or knowledge of the insurance company.

The facts leading to the Rocco case were that an application for automobile insurance was made through the general agent of the insurer. The application contained the question: "Has any company cancelled, declined to renew or issue automobile insurance to the insured?", to which the plaintiff answered "no". In fact the plaintiff had two previous policies of automobile insurance cancelled. This application was signed by the plaintiff. The agent of the insurer was fully aware of the cancellation of earlier policies.

Following a claim, the insurer repudiated liability on the ground of misrepresentation as discussed above. An action was brought to recover indemnity under the contract of insurance. It was contended on behalf of the plaintiff that the authority of the agent to issue policies prevented the insurance company from disputing the contract or setting up misrepresentation as a defence. Hodgins J.A., of the Supreme Court of Ontario, Appellate Division, rejecting the contention of the plaintiff, remarked:460

I do not think the agent's authority included the right to deliver a policy containing a misstatement which, to the knowledge of the agent himself, would make it void... [his] was a fraudulent act as against the company, not covered by any authority possessed by him.

Middleton J.A., of the same court, discussing the effect of knowledge possessed by the agent, said:461

... notice to or knowledge of an agent is not notice to or knowledge by the company unless the circumstances are such as to justify the opinion that the agent would be likely to communicate the information to those in charge of the affairs of the company.

According to Middleton J.A., the insurer will not be bound by the acts of the agent unless it can be established that the insurer actually knew about the true facts, or, having received notice thereof, failed to rescind the contract entered on his behalf. The Newsholme rule was thus follow-

499 [1930] 1 D.L.R. 472, 64 O.L.R. 559.

160 Id. 64 O.L.R. 559 at 562.

461 Id. 
ed. The result may be fair in that the insured committed a fraudulent act, but the reasoning of the court is open to question on several other grounds.

It is respectfully submitted that the approach of Middleton JA., as reflected in the above statements, is based on fiction. When the management of an insurance company appoints an agent to act on its behalf, they must ensure that the person selected is of high moral character with sufficient background in insurance and other education. Moreover, he should be honest, and should be sufficiently remunerated so that his personal interest in earning the commission does not override the interests of the insurer and insured. In spite of this, if the agent acts fraudulently against the company, or, if he acts honestly but prejudices the interest of the company, there is no reason why the insurer should not be bound by the acts of its agents. It seems manifestly unfair to allow insurers to benefit from the profitable acts of their agents and to disclaim responsibility for those which are prejudicial to their interests while also retaining the premiums. The duty of the agent is to act in the best interest of the insurers and the insuring public, but if the agent does breach his duty, the insurer should have the normal recourse in agency against him. Thus, agents can be penalized for their fraudulent or negligent conduct without penalizing innocent insurance consumers.

The fictional aspect of the opinion of Middleton J.A. may now be contrasted ${ }^{462}$ with the approach of Taylor J.A., in Mount Hope v. Findley.463

An express notice to a treasurer of a municipality is not constructive but actual and express notice to the municipality when the matter pertains to the functions of the treasurer. In law it is the municipality acting, not the treasurer.

This approach is to be preferred because it protects the interest of the public dealing with the municipality through its representative, the treasurer. Notice to or knowledge of the agent should likewise be treated as notice to or knowledge of the insurance company and the latter should be bound by any fraudulent act or failure on the part of its agent to discharge his duties properly.

The case of Salata v. Continental Ins. Co., ${ }^{464}$ was decided on grounds similar to those in the Rocco case. In Salata, the facts of which have been discussed earlier, ${ }^{465}$ the plaintiff applied for fire insurance through the soliciting agent of the insurer, who had no authority to bind the company. The application was completed by the agent and signed by the applicant. The plaintiff, to the knowledge of the agent, misrepresented that his farm had oil burning equipment which operates without a chimney. In fact there was no such equipment installed at that time. Instead, the plaintiff later used a home made apparatus of his own contrivance, which increased the fire hazard resulting in damage and the claim in question. The insurer denied indemnity to the plaintiff, alleging misrepresentation and fraudulent omission. The question to be determined was whether the knowledge acquired by the agent during negotiations and as a result of inspection of the premises was to be imputed to the company.

McFarland J., gave judgement for the insurer and was affirmed on

\footnotetext{
162 Crawford, Cases on the Canadian Law of Insurance 252 (1971).

4015 Sask. L.R. 40, [1921] 3 W.W.R. 658, 66 D.L.R. 660 (C.A.).

${ }^{64}$ [1948] O.R. 270, 15 I.L.R. 38, [1948] 2 D.L.R. 663, affirming 14 I.L.R. 26 (C.A.).

46 Supra, n. 117.
} 
appeal. Robertson C.J.O., cited the Newsholme case as authority for the proposition that the agent, in filling the proposal form, is considered the amanuensis of the proposer and that the knowledge of true facts possessed by the agent is not to be imputed to the insurance company. The judge also quoted the following passage from the decision of Supreme Court of United States in New York L. Ass. Co. v. Fletcher:466

It would induce great uncertainty in all business transactions, if a party making written proposals for a contract, with representations to induce its execution, should be allowed to show, after it had been obtained, that he did not know the contents of his proposal, and to enforce it, notwithstanding their falsity as to matters essential to its obligation and validity. Contracts could not be made, or business fairly conducted, if such a rule should prevail; and there is no reason why it should be applied merely to contracts of insurance.

The appeal was dismissed and the insured was unable to recover in spite of the fact that the agent had inspected the farm premises and inserted wrong answers in the application.

In regard to the above opinion of the Supreme Court of the United States, it is respectfully submitted that this opinion puts "business convenience" above the interest of the insuring public. Moreover, the nature of insurance transactions compels the proposed insured to rely heavily on the agent of the insurer. The applicant is not possessed with a knowledge of materiality and the requirements of the insurance company. The proposer, by allowing the agent to fill in the form, does not necessarily authorize him to supply incorrect answers, and it would be unfair if the agent could earn his commission and the insurance company retain the premiums without any fault on the part of the insured. The agent being the representative of the insurance company, the latter must suffer the consequences of the agent's acts or omissions.

\section{(a) Exceptions to the Newsholme Rule}

The most frequent exception to the "rule" is the case of "apparent authority" where insurers have held out their agents as having authority and the proposer has relied on such holding out and prejudiced its position. The courts, in such instances, have held that insurers are bound by the acts of the latter which are within the scope of their ostensible authority. The cases of Berryere v. Fireman's Fund Ins. Co. and Murray, ${ }^{467}$ and Jensen v. South Trail Mobile Ltd., ${ }^{468}$ on the subject, have been discussed earlier.469

Apart from the cases on apparent authority, the courts in Canada have found exceptions to the Newsholme rule where the applicant for insurance is illiterate or unable to read or understand English and the agent, having inserted wrong answers, does not read or explain them.

In Istvan v. Continental Casualty 470 the plaintiff, a foreigner, who could not read or understand English, applied for accident insurance coverage through the insurer's agent. The application containing false answers was filled in by the insurer's agent. The false answers were neither read nor explained to the applicant in any language which he understood.

\footnotetext{
466 (1886) 117 U.S. 519 at 529.

67 (1965) 51 D.L.R. (2d) 603.

488 (1972) 28 D.L.R. (3d) 233.

${ }^{469}$ Supra, n. $400,405$.

40 [1941] 2 W.W.R. 512
} 
Following the issuance of the policy, the plaintiff was shot and consequently became wholly incapacitated. A claim was lodged against the insurer who denied liability on the ground that the insured had failed to disclose in the application the existence of a previous policy, a claim thereunder and cancellation of policy. The evidence established that the agent did not ask any question about the facts misrepresented. Rather, the agent managed to get the blank application form signed by the plaintiff and filled in the information afterwards. O'Conner J., of the Alberta Supreme Court, accepted the testimony of the plaintiff and rejected that of the insurer's agent. The court found that the plaintiff did not make a misrepresentation.

The insurer, citing the Newsholme case as authority, contended that the insured by signing the proposal form had bound himself and by bringing the action adopted the policy containing untrue statements. The judge, dealing with this contention, remarked:471

It seems to me it cannot fairly be said that the plaintiff signed a promise that certain statements were true and as he could not read them he could not know them to be untrue.

The case was decided in favour of the insured and the insurer was required to pay. A number of cases ${ }^{472}$ were cited by the defendant where the agent had written false answers. These were distinguished on the ground that in all those cases, the insured could have read the policy and it could fairly be said that he might have adopted it.

Where the applicant would have read the proposal form and considered that the answers were true in spite of the misrepresentation made by insurer's agent, the proposer is not bound by them although he signed the application without reading it. This is evident from the case of Lewis v. Northern Assurance Co., ${ }^{473}$ which has been discussed earlier. ${ }^{474}$

The protection offered by such decisions is limited to the rather exceptional facts giving rise to these cases. It is submitted that even where the insured can read and understand the contents of the proposal form but does not do so in reliance upon the agent, he should be extended similar protection, as is the case in Quebec.

(i) Insurer's agent explaining terms-Quebec position

The courts in Quebec have found that the agent in explaining terms of the contract, is the agent of the insurer.

In Great West Life Ass. Co. v. Paris, ${ }^{475}$ the applicant, a young hockey player, on the suggestion of the plaintiff's agent, took out an accident insurance policy. The application form contained the question: "(8) Do you participate in .... any of the following organized sports: football, rugby, lacrosse, hockey, ...?" The applicant asked the agent about the implication of the term "organized sports" to which the agent replied that it signifies an organization where players are rewarded for their participation in sports. The applicant, on being told this, answered the question in the negative. This was written by the agent in the application form

471 Id. at 516 .

${ }^{42}$ Biggar v. Rock Life Ass. C. [1902] 1 K.B. 516, 71 L.J.K.B. 79; Sereda v. Consolidated Fire and Casualty Ins. Co. [1934] O.R. 502; St. Regis Pastry Shop and Baumgartner v. Continental Casualty Co. (1928) 63 O.L.R. 337, [1929] 1 D.L.R. \&00 (C.A.); Dorsht v, Trasn.Canada Ins. Co. [1933] O.R. 98.

433 (1956) 4 D.L.R. (2d) 496, [1956] O.R. 404, [1956] I.L.R. 1-221.

474 Supra, n. 361.

475 [1959] Q.B. 340 (C.A.). 
for insurance. The agent at that time fully knew that the insured was intending to play hockey as a member of an amateur hockey club.

The insured was totally incapacitated following a knee injury in a hockey game. A claim was rejected by the insurer who deposited, into court, the premium paid by the insured and sought a declaration voiding the policy.

The agent responsible for the misrepresentation was a fully accredited agent of the company. He was supplied with stationery, proposal forms, manuals, authorized to collect premiums and issue receipts therefor. The agent had also undertaken special agent's courses.

The trial court awarded judgement in favour of the insured which was affirmed on appeal. Galipeault C.J. discussing the position of the agent in explaining the terms of the contract, said:478

In furnishing [Paris] with the above mentioned explanations, the agent was acting on

behalf of the insurer whom he represented exclusively, and this agent was acting within the terms of his authority... Armed with this mandate, [authority to act as a fully accredited agent] it does not seem possible that Auger was not the [insurer's] agent when [Paris] signed the application on company forms, particularly when Auger filled in the forms in the circumstances mentioned.

The Chief Justice also found for the respondent on the ground that the appellant had not taken the precaution of indicating in the application form that the agent had no authority to explain or advise about the questions. Furthermore, the Chief Justice found that the term "organized sports" was ambiguous and, therefore, construed the contract contra proferentem.

The case was decided on just and reasonable grounds because the respondent had reason to believe that the agent in negotiating the contract had the authority to explain its terms.

In another Quebec case of Compagnie Equitable v. Gagne, 477 the agent, in explaining the scope and intent of a question, was treated as the agent of the insurer. The case has been discussed earlier. ${ }^{478}$ and will be briefly taken up here.

In the Gagne case, the agent of the company, in completing the application form, represented in good faith that the applicant did not have to reveal the previous two accidents as no claim on any insurer was involved. The agent was the general agent with authority to bind the insurance company. Following a claim, the insurer denied liability for non-disclosure of previous accidents and sought a declaration from the court avoiding the automobile policy. This was not granted by the trial court. In an appeal to the Quebec Court of Appeal, Choquette J A., adopted the following opinion of Hyde J. in Great-West Life Ass. Co. v. Paris. ${ }^{479}$

...the insurer's agent was his duly authorized representative for the purpose of soliciting and receiving applications for insurance and as the insurer has not taken the precaution of indicating in the form that the agent had no authority to interpret or advise in connection with the question asked therein, the agent's action in doing so was within his apparent authority and the applicant was entitled to assume that he could rely upon his assistance. The insurer is bound by the act of its agent within the scope of his authority and cannot complain of the answer given.

\footnotetext{
47 Crawford, Cases on the Canadian Law of Insurance 268 (1971).

477 (1966) 58 D.L.R. (2d) 56 (Que. C.A.).

478 Supra, n. 255.

479 [1959] Que Q.B. 340 at 349-50 (C.A.).
} 
Mr. Justice Hyde's opinion was based, inter alia, upon the following passage from Porter, Law of Insurance:480

... if the agent puts his own construction on facts stated by the assured, and deduces an erroneous answer, which he writes down assuring the applicant that it is the proper one on the facts stated and the one that the insurer wants, the insured is not precluded by his warranty from showing the circumstances under which the answer was made.

The result of the Gagne case was that the appeal of the insurer was dismissed and the insured was able to recover.

It may be noted that Quebec Courts have recently decided the two cases of Patrick v. Maryland Casualty Co. ${ }^{481}$ and Levinson v. Canada Life Ass. Co., ${ }^{482}$ in which the agent was treated as the representative of the company. The cases did not involve any non-disclosure or misrepresentation. In the Patrick case the insured had verbally informed the agent about the loss, who notified the wrong insurer. In the Levinson case the agent had told the insured, while applying for conversion of a term policy, that he was fully covered pending approval of head office. Following a claim before the acceptance of the application, the insurer was required to pay.

(ii) Insurer's agent not explaining terms

In Valgardson v. Contingency Ins. Co. ${ }^{483}$ decided by the Manitoba Queen's Bench, the insurer's agent had failed to explain to the plaintiff the significance of the word "select" written by him in the application for automobile insurance. It was held that where the agent is authorized to negotiate a contract, he has, by necessary implication, authority to explain the terms of the contract and, if he fails to discharge this duty, the insurer will be liable for the loss. This case has been discussed in detail earlier.484

(iii) Agent answering questions with a dash

The position would be different from the one discussed above, where the agent of the insurer does not answer the question in the application, but merely inserts a dash.

In the case of Gabel v. Howick Farmers Mutual Fire Ins. Co.485 the agent had authority to receive applications, collect premiums, issue interim receipts and to bind the company. The plaintiff, who had carried insurance with the defendant in the past, told the agent that he apprehended incendiarism and desired increased insurance. The plaintiff signed a blank application form which was later filled in by the agent, who answered the question relating to incendiarism with a dash. The application specifically provided that the agent, in completing the proposal form, was to be the agent of insured. A fresh policy with increased coverage was issued by the insurer on the basis of this application. Following a loss by incendiarism, indemnity was denied to the insured.

Masten J., of the Ontario High Court, found that the agent, acting in a dual capacity, had failed to discharge his duty to either by not answer-

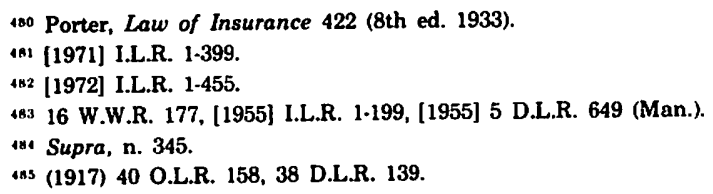


ing the question in the application or by not disclosing the material facts to the insurer. The learned judge remarked:486

If the question 'Is incendiarism threatened or apprehended' had been answered 'No', I would have no difficulty in determining that the plaintiff Gabel was responsible for misrepresentation of material fact, and that the company were not liable on the policy ... If, on the other hand, this question had not been printed on the application, ... notice to such an agent as Fallis was notice to the company but the actual situation is neither the one nor the other of these.

The defendant had accepted the risk without requiring an answer to the question of incendiarism. The judge, therefore, found that the insurer had waived the question in the printed application. As to the disclosure made of the agent, the judge remarked:487

I think that was disclosure to the company [referring to the disclosure made dehors the answers in the application] and that any provision to the contrary in the conditions or in the application is unreasonable, and therefore ineffective.

The judge, however, made it clear that he was not laying down a general proposition but was confining his ruling to the facts of the case.

The insured was saved from the act or omission of the agent as the court had found a waiver of information. If the question had been answered in the negative, the insurer would have been bound by the misrepresentation of the agent.

In Hanson v. Queensland Ins. Co.488 the plaintiff had applied for fire insurance coverage through the insurer's agent. The application was completed by the agent and signed by the plaintiff without reading it. The agent had placed a dash in answer to a question relating to cancellation of a previous fire policy. Following a claim, the liability was avoided on the ground of fraudulent non-disclosure or misrepresentation of previous insurance. An action was brought to recover indemnity. The agent testified that the plaintiff did not tell him about the cancellation of his earlier policy and the insurer's refusal to renew it. The agent also pleaded that his practice was to place a dash in response to questions where the answer was negative or inapplicable.

Kerby J., of the Alberta Supreme Court, accepted the testimony of the insurer's agent and found that the plaintiff's oral answer to the question was that no previous policy of fire insurance had been cancelled in respect of the same risk. The judge concluded that there was fraudulent omission or misrepresentation on the part of the insured which avoided the policy. The practice of the agent in placing a dash where the answers were negative or inapplicable was accepted by the court as correct. The plaintiff was, therefore, unable to recover.

The decision in this case may be contrasted with the approach reflected in the Gabel case where the court had found that the insurer, by accepting an application with a dash and without requiring an answer to the question, had waived the question in the printed application and that disclosure outside the written answers was disclosure to the company.

In the Hanson case the approach of the court was different because it felt that the insured had told a lie. The result of the case may be fair but it is submitted that the court should have laid down a qualified ruling

486 Supra, n. 485 at 164.

487 Id.

${ }^{88} 56$ W.W.R. 215, 57 D.L.R. (2d) 131, [1966] I.L.R. 1-171 (Alta. S.C.), 
that where a question is answered with a dash and the non-disclosure results as a fault of the agent, the insurer is deemed to have waived the information. Such a "rule" might prevent this decision from being indiscriminately followed by the courts in future.

The approach in the Gabel case is to be preferred because it protects the legitimate interest of the innocent insured.

In Manitoba, ${ }^{489}$ however, an answer penned with a dash has been treated as a negative answer.

It is submitted that in the absence of clear-cut legislation a shrewd agent, in the Provinces of Alberta and Manitoba can get away from the effect of false answers merely by placing a dash and the insurer, by retaining the premiums, will benefit from the act or omission of its agent. This is potentially injurious to the interest of the insuring public and calls for suitable statutory amendments.

(iv) Agent completing blank portions of application already signed by insured

An attempt will now be made to show the effects of a misrepresentation made by the insurer's agent where he completes blank portions of a proposal form already signed by the insured.

In Blanchette v. C.I.S. Ltd., ${ }^{490}$ a case recently decided by the Supreme Court of Canada, the insured had applied for fire insurance coverage for its granary and for a public liability policy through the insurer's agent. Answers to a number of questions in the application were written down by the agent and the plaintiff merely signed the application without reading it or having it read over. Two days after the execution of the form, the plaintiff applied for another type of coverage, i.e., automobile insurance for his tractor. The agent advised the plaintiff that he need not complete another application form. Rather, the plaintiff should give him the serial number of the vehicle and the agent would complete the portion of the application dealing with "Farm Equipment" which was not filled in when the application was signed. The serial number of the vehicle was furnished to the agent who later completed the form and submitted it to the insurer. No policy was, however, issued before the loss.

The agent, at the time of application for insurance, had represented to the plaintiff that he was covered until the company rejected the application. The application was rejected fifteen days after the execution of the application. In the meantime the loss had occurred. The question to be determined was whether Raiche, the insurer's agent, had authority to bind the company between the date of the application and the time it was either accepted or rejected by the insurer.

The insurer also denied liability on the ground that the insured had given a false answer to the question: "Will any farm equipment be used for logging, forestry, brush cutting or saw mill operations?" The insured admitted that the tractor was to be used for brush cutting which was a "real bad" fire hazard, but contended that the questions concerning the farm equipment were never put to him by the agent nor answered by him.

The agent was authorized not merely to solicit business but also to fill

${ }^{489}$ Hoey v. Merit Ins. Co. [1971] I.L.R. 1.417 at 1274. For a discussion see supra, n. 371.

480 (1973) 36 D.L.R. (3d) 561 (S.C.C.). 
in the application forms. He was supplied with rate manuals, empowered to collect premiums and issue receipts therefore.

Judgement at trial given in favour of the plaintiff was reversed on appeal to the Saskatchewan Court of Appeal on the ground that the agent was acting as the agent of the insured and not of the insurance company. On further appeal to the Supreme Court of Canada, Pigeon J., in a majority judgement, decided in favour of the appellant on the basis that the insured had no means of verifying the correctness of the answers later written by the agent. As to the effect of false-answers inserted by the agent, after the plaintiff had signed the form, the judge remarked:491

I cannot agree that an applicant for insurance who signs an application form leaving a part concerning 'farm equipment' completely blank and who later applies for this type of coverage and authorizes by telephone the company's agent to complete the form for that coverage, must be in the same position at law as if he had signed the form without reading answers previously entered by the agent ... he [the applicant] had no means of verifying the correctness of the form as completed. In my view, it is unfair to hold that he should suffer the consequences of Raiche's [agent's] failure to complete the form properly.

\section{In his dissenting opinion Ritchie J. stated:492}

... an applicant for insurance who ... authorizes the agent by telephone to fill in a part of the application which had been left in blank over his signature is in the same position at law as an applicant who has signed a form without having read the answers which have previously been entered upon it by an agent.

The majority opinion of the Supreme Court of Canada is to be preferred because the insured did not have any opportunity to verify the correctness of the answers later written by the agent. In fact the insured had requested the agent to come to his place and complete another form which the agent declined to do for reasons discussed above.

The results of the case are desirable inasmuch as the agent in completing the blank portions of the form already signed was treated as the agent of the insurer. The findings of the Supreme Court of Canada in this case may be compared with the recommendations of the U.K. Law Reform Committee which, inter alia, provide:493

(3) that any person who solicits or negotiates a contract of insurance should be deemed, for the purposes of the formation of the contract, to be the agent of the insurers, and that the knowledge of such person should be deemed to be the knowledge of the insurers.

Although the approach of the Supreme Court of Canada, as reflected in the decision of Blanchette 494 is not entirely in conformity with the above recommendation, it is a step in the desired direction.

It may be asked why the agency concept of "holding out" or agency by estoppel is not more often used in order to bind an insurer by its agent's acts. The normal law of agency in this respect seems curiously inoperative in insurance law, obliging the consumer to make his own enquiries at his own risk as to an agent's power to bind the insurer. This anomaly may be explained, perhaps, by the prevailing view that the agent is really the agent of the applicant, such as propounded by the

\footnotetext{
491 Id. at 576-77.

492 Id. at 569.

493 U.K. Law Reform Committee Fifth Report, para. 14 (1957).

494 Supra, n. 491.
} 
"Newsholme rule". This common law approach is in serious need of revision by statute.

The problem of disclosure through the insurer's agent will not be completely eliminated until such time as an agent in soliciting or negotiating an insurance contract is regarded as the agent of the insurer.

It is time to end the agent's dual representation and to eliminate a situation open to conflict of interest. An insurance applicant should be protected against an agent's wrongdoing, save in cases of the insured's own fraud.

In summary, the trend of decisions indicates that in Quebec, where non-disclosure or misrepresentation is made in the application by the insurer's agent, the application is binding on the company. ${ }^{495}$ Furthermore, the agent, in explaining the terms of the contract ${ }^{496}$ or the intent or scope of the question, ${ }^{497}$ is treated as the agent of the insurer. The extreme effects of the Newsholme rule have thus been circumvented in Quebec.

In other provinces the Newsholme rule has been followed. The agent in filling the application form is regarded as the amanuensis of the proposer. ${ }^{498}$ Any knowledge possessed by the agent which is inconsistent with the disclosures made in the application is not imputed to the insurer. This is based on the ground that if the agent knows about the falsity of the answers, he is committing fraud upon the company which prevents his knowledge being the knowledge of the company. Furthermore, if he does not know the true answers, the knowledge cannot be imputed to the insurer.499

The cases also show that where the applicant can read the proposal form but signs the same without reading it, he adopts the answers written by the agent as his own and cannot later complain about the non-disclosure or misrepresentation made by the agent. ${ }^{500}$

In line with Quebec decisions, it has been held in Manitoba that where an agent is permitted to negotiate a contract of insurance, he has, by necessary implication, authority to explain the terms of the contract and if he fails in his duty, the insurer is liable. ${ }^{501}$

It may be noted that in the United States, by the overwhelming weight of authority, the agent in filling in the application form is considered to be the agent of the insurer whether the incorrect answers written by the agent result through inadvertence, mistaken judgment, or fraud of the agent. ${ }^{502}$ The doctrine that the agent, in receiving premiums and delivering policies of insurance, is the agent of the insurer, and as to all other acts is the agent of the assured, has not been accepted in all the states of the United States. ${ }^{503}$ The reason for this has

\footnotetext{
495 Union Ins. Co. of Paris v. Monette (1924) 38 Que. K.B. 309; Great West Life Ass. Co. v. Paris [1959] Que. Q.B. 340 (C.A.); Compagnie Equitable v. Gagne (1966) 58 D.L.R. (2d) 56 (Que. C.A.).

${ }^{196}$ Great West Life Ass. Co. v. Paris [1959] Que Q.B. 340 (C.A.).

497 Compagnie Equitable v. Gagne (1966) 58 D.L.R. (2d) 56 (Que. C.A.).

49k Rocco v. Northwestern National Ins. Co. 64 O.L.R. 559, [1930] 1 D.L.R. 472 (C.A.); Salata v. Continental Ins. Co. [1948] O.R. 270, 15 I.L.R. 38, [1948] 2 D.L.R. 663, affirming 14 I.L.R. 26 (C.A.).

499 Id.

sou Sereda v. Consolidated Fire and Casualty Ins. Co. [1934] O.R. 502; St. Regis Pastry Shop and Baumgartner v. Continental Casualty Co. (1928) 63 O.L.R. 337; [1929] I D.L.R. 900 (C.A.); Dorsht v. Trans-Canada Ins. Co. [1933] O.R. 98.

so1 Valgardson v. Contingency Ins. Co. [1955] 5 D.L.R. 649, 16 W.W.R. 177, [1955] I.L.R. 1-199.

502 Vance on Insurance 461 (3d ed. 1951).

s03 (1872) 13 Wall. 222, 20 L. Ed. 617; see Vance supra, n. 419 at $462-63$.
} 
been stated by the learned Miller J. in the leading case of Union Mutual Ins. Co. v. Wilkinson:504

But to apply such a doctrine, in its full force to the system of selling policies through agents, ... would be a snare and a delusion leading as it has done in numerous in. stances, to the grossest frauds, of which the insurance corporations receive the benefits, and the parties supposing themselves insured are the victims.

Miller J. also made the following remarks regarding the responsibility of the insurer for the acts of its agent:505

An insurance company, establishing a local agency, must be held responsible to the parties with whom they transact business for the acts and declarations of the agent, within the scope of his employment, as if they proceeded from the principal.

A number of cases were cited in support of the proposition..$^{506}$

In conclusion it is submitted that any meaningful protection for the insuring public from the consequences of agents' acts or omissions must depend mainly upon statutory provisions. Such provisions should be framed in light of the precedents discussed above in Quebec, ${ }^{507}$ the United States, ${ }^{508}$ and the recommendations of the U.K. Law Reform Committee. ${ }^{509}$

\section{Critique of the Case Law}

\section{CONCLUSIONS}

The cases discussed in the two preceding chapters have borne out the thesis that consumers of insurance in Canada and England have been placed in a disadvantageous position, by reason of a strict duty to disclose material facts to the insurer at their own initiative, while applying for coverage either personally, or through the insurance agent.

A. General

The difficulties of the consumer are increased by reason of the doctrine that an agent in filling out the application is the agent of the insured, ${ }^{510}$ and that any non-disclosure, ${ }^{511}$ misrepresentation, ${ }^{512}$ or fraud ${ }^{513}$ terminates the insured's right of recovery under the policy. It is submitted that section 490 of the Alberta Insurance Act, 514 authorizing the Superintendent of Insurance to revoke the certificate of authority of any agent, where he is found to have been guilty of misrepresentation, fraud, deceit or dishonesty, does not sufficiently protect the interest of the consumer.

An insurance applicant should be protected against an agent's wrong doings, save in cases of the insured's own fraud. Insurers should be allowed to protect themselves against the unfaithful acts of their agents, but not at the cost of consumers of insurance. In the light of precedents

sos Id.

sos Id. Vance at 463.

506 Woodbury Sav. Bank \& Bldg. Ass'n. v. Chater Oak Fire and Marine Ins. Co. (1863) 31 Conn. 517; Ayres v. Ins Co. (1864) 17 Iowa 176, 85 Am. Dec. 553; Horwitz v. Ins. Co. (1867) 40 Mo. 557, 93 Am. De. 321 ; Howard Ins. Co. v. Burner (1854) 23 Pa. 50.

507 Insurance Act, R.S.Q. 1964, c. 295, 8. 240, Stat. Condition 1.

so: See Vance on Insurance 461 (3d ed. 1951).

sog U.K. Law Reform Committee, Fifth Report, para. 14 (1957).

s10 Salata v. Continental Ins. Co. [1948] 2 D.L.R. 663, [1948] O.R. 270, 15 I.L.R. 38, affirming 14 I.L.R. 26 (C.A.).

sil Rocco v. Northwestern National Ins. Co. [1930] 1 D.L.R. 472, 64 O.L.R. 559 (C.A.).

S12 Id.

${ }^{313}$ Abbi v. Klippert and State Farm Fire and Casualty Co. (1969) 68 W.W.R. 426, [1969] 1.L.R. 1-286 (Alta. S.C.).

sit Supra, n. 51. 
in Quebec ${ }^{515}$ and the United States, ${ }^{516}$ and the recommendation of the U.K. Law Reform Committee, ${ }^{517}$ it is suggested that an agent, in soliciting or negotiating a contract of insurance, should be deemed to be the agent of the insurer for all purposes of disclosure, and any knowledge of material facts possessed by the agent should be regarded to be the knowledge of the insurer irrespective of the class or category of agent involved.

A second problem area arises because the materiality of facts required to be disclosed is judged solely from insurers' point of view. ${ }^{518}$ This has added insult to the injuries of consumers of insurance. An honest and prudent insured may not know until after the claim has arisen that certain facts were allegedly material. whereas an insurer, having the vast experience of the insurance industry, a huge inventory of claims to rely upon, and its own means of inquiry, has been in a position all along to know which facts are material. Moreover, legislatures have not yet taken any step to point out to the insuring public what facts are material, disclosure of which are essential at the time of original application or upon renewal.

The courts have accepted as the test of materiality that of a "reasonable insurer". ${ }^{519}$ An insurer, by calling its paid officials, may establish that the facts in question were material from its point of view without being required to prove the practice of a reasonable insurer. ${ }^{520}$ This may lead to the replacement of the "reasonable insurer's" test of materiality by a test of the "particular insurer". Moreover, the legal test of materiality being that of a "reasonable insurer", the basic clause still operates against the insured.

It is suggested that the reasonable insurer's test is not at all desirable and should be replaced by the test of a "reasonable insured" as suggested by Mignault J., of the Supreme Court of Canada, in the leading case of Mutual Life Ins. Co. v. Ontario Metal Products ${ }^{521}$ and the U.K. Law Reform Committee.522 If the reasonable insurer's test is to be maintained, it is suggested that the insurer should at least be required to prove that its view of what facts are material is in harmony with reasonable practice in the insurance industry. For this purpose, the opinion of independent expert witnesses drawn from the insurance industry should be required to show the reasonableness or otherwise of the practice in question.

The burden of proving the unreasonableness of an insurer's practice has apparently been shifted to consumers of insurance. This is an unduly heavy burden on the insured. In view of his relatively weak financial position, the insured is generally unable to prove the materiality or otherwise of facts allegedly concealed or misrepresented. It is submitted that the unopposed testimony of the insurer's paid officials, who may give partial evidence, should not be accepted as sufficient discharge of the onus upon the insurer.

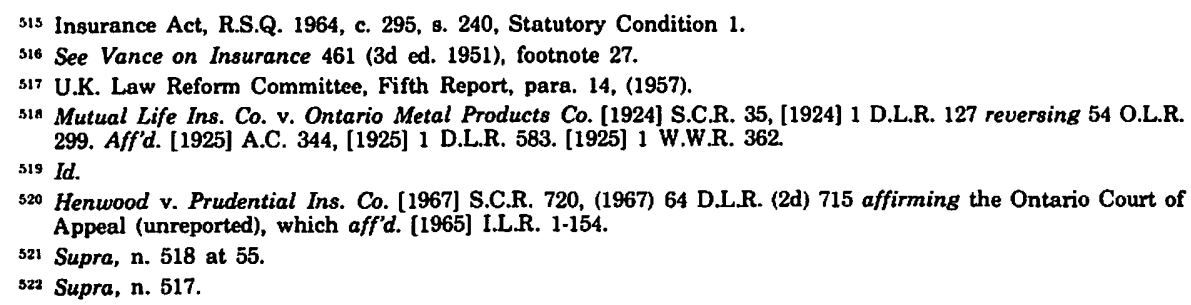


It is suggested that evidence of expert witnesses not employed by the insurer, and preferably drawn from the insurance industry and Insurance Bureau of Canada, be accepted as tending to show the reasonableness or otherwise of the practice in question. Even in cases where the individual insurer establishes that its practice was not inconsistent with other companies, the courts should examine whether such a practice by the insurance industry is a healthy one.

Moreover, the cost of engaging experts should be borne by the defending insurer, irrespective of the outcome of the case, because a finding on materiality will benefit the insurance industry. The relatively weak financial position of the insured justifies such a course of action.

An insurer should not be allowed to raise a legal defence based on misstatement of facts where the insured can establish that the disclosure in the proposal form was true to the best of his knowledge and belief. ${ }^{523}$ The insured should only be penalized where he acts in bad faith. The onus of proving bad faith must be on the insurer.

Life insurance contracts in Canada can be avoided for innocent nondisclosure or misrepresentation, ${ }^{524}$ and fire insurance contracts for innocent misrepresentation. ${ }^{525}$ This has further prejudiced the position of the insured. In the absence of knowledge of the materiality of facts on the part of the insured, insurers should not be allowed-to repudiate liability on the ground of innocent non-disclosure or misrepresentation.

Moreover, the cases have also demonstrated that under a life insurance policy an insured who deliberately conceals or misrepresents material facts ${ }^{526}$ suffers different consequences than an innocent insured who makes a misrepresentation honestly and in good faith. ${ }^{527}$ The former type of insured has been subjected to a repudiation of his contract without a return of premium. So long as the defence of innocent nondisclosure or misrepresentation is available to the insurer, any meaningful reform in this area will not be possible.

The cases have shown that an insured in Canada may be under a strict duty to disclose material facts within his knowledge about which no question is asked in the application, whether the insured thought them material or not.528 It is submitted that this is too much to expect from consumers of insurance. The insured in England is required to disclose at his own initiative every material circumstances known or which ought to be known by him. ${ }^{529} \mathrm{~A}$ Canadian insured is, therefore, somewhat better placed than his counterpart in England. The insurer has not been legally compelled to frame questions in such a manner as to elicit all the material information needed. It is suggested that insurers be placed under a statutory duty to frame specific and appropriate questions before being allowed to base a legal defence upon the non-disclosure of allegedly material facts. They should be precluded from asserting any defences

\footnotetext{
323 Id.

s24 Insurance Acts: R.S.A. 1970 , c. 187 , s. 240 ; R.S.B.C. 1960 , c. 197, s. 123(1); R.S.M. 1970, c. 1-40, s. 160; R.S.O. 1970 , c. $224,8.157$.

325 Insurance Acts: R.S.A. 1970, c. 187 , 8. $223(1)$; R.B.C. 1960 , c. 197 , 8. $208(1)$; R.S.M. 1970 , c. I-40, 8. 142(1); R.S.O. 1970 , c. 224 , s. $122(1)$.

s26 Vanini v. Prudential Ins. Co. [1945] 3 D.L.R. 492, [1945] O.W.N. 500, 12 I.L.R. 152.

327 Murphy v. Sun Life Ass. Co. 49 D.L.R. (2d) 412, 50 W.W.R. 581, [1965] I.L.R. 1-142 at 708 affirming 44 D.L.R. (2d) 369, 47 W.W.R. 47, [1964] I.L.R. 1-124 (Alta. A.D.).

s2s Id.; Chapman v. Accident Fire Ins. Co. (1929) 37 O.W.N. 320.

s29 Lindenau v. Desborough (1828) 8 B. \& C. 586; Joel v. Law Union and Crown Ins. Co. [1908] 2 K.B. 863 (C.A.).
} 
based on non-disclosure of facts which fall outside the purview of questions asked.

Apart from the necessity of specific questions, the law in all provinces should require insurers to print in a conspicuous manner not only the statutory duties, but also the rights of the insured.

The average insurance consumer has rarely, if ever, enjoyed a strong economic position from which to negotiate the terms of his insurance contracts. What room to negotiate he might have enjoyed historically has disappeared in an age of giant insurance companies and "fine print" standard policies given approval under statute. The Consumer Affairs Act of Alberta ${ }^{530}$ and the Consumer Complaint Officer ${ }^{531}$ in the office of the Superintendent of Insurance in Alberta, do not provide sufficient protection for consumers of insurance.

Presently, the Superintendents of Insurance in the various provinces of Canada are vested with wide powers to scrutinize and approve application forms and policies. The task of screening may require expertise beyond that presently available in the offices of the Superintendents, especially in view of their other important functions such as the scrutiny of the financial affairs of insurers established under present legislation.

It is suggested that application forms, policies, endorsements, renewals or continuation certificates drafted by insurers should be the subject of thorough screening and approval by a tribunal consisting of consumer representatives and legal and insurance experts. An appeal against decisions of the tribunal should lie to the provincial Supreme Court. Where, however, insurance companies do not submit their forms to the tribunal or fail to secure its approval, the law should provide that any defence based on breach of policy terms, warranty or conditions will not be entertained by the courts. Moreover, the provincial Superintendents of Insurance should attempt to remedy the lack of uniformity and cohesiveness in each of the provincial insurance statutes and direct their efforts toward the improvement of the law in the important area of the duty of disclosure.

It is also suggested that some kind of advisory or educational body be set up to explain essential features of insurance to consumers in order to acquaint them with the requirements of the insurance industry and their statutory rights and duties.

It is submitted that the unequal application of the so-called doctrine of uberrima fides is to a great extent responsible for the difficulties encountered by insurance consumers. The duty of disclosure is reciprocal but seems to be exacted only from the proposer for insurance. The onus of good faith on the insurer is manifested by a tendency of the courts to construe contra preferentem, ${ }^{532}$ to find estoppel against the company, ${ }^{533}$ to lean in favour of insurable interest, ${ }^{534}$ and to relieve against forfeiture $^{535}$ where possible. But this is not sufficient because the courts do

\footnotetext{
s30 R.S.A. 1970, c. 64.

s31 There is no Consumer Complaint Board in the office of the Superintendent of Insurance in Alberta. An In. vestigation Officer, with two assistants, hear the complaints of consumers to bring about compromises but have no authority to enforce their decision.

332 Fordorchuk v. Car \& General Ins. Corp. [1931] 3 D.L.R. 387, [1931] 2 W.W.R. 586 (Alta. S.C.).

s33 Parise v. Can. Security Ass. Co. 51 D.L.R. (2d) 193, [1965] 2 O.R. 482.

534 Wolfe v. Oliver (1973) 34 D.L.R. (3d) 669.

s3s Supra, n. 532.
} 
not uniformly make use of these devices. ${ }^{536}$ It is suggested that uberrima fides must be fairly applied to both the parties.

It is proposed that the law should also provide against misrepresentation and false advertising by insurers as to policy contracts and the benefits offered.

The courts have accepted the ex-post facto plea of insurers' officials that if the facts allegedly concealed or misrepresented had been truthfully disclosed, they would have required a higher premium or declined the risk. ${ }^{537}$ It is submitted that this contention, even if acceptable, should not allow insurers to repudiate liability as they gain premiums as a windfall profit. It is suggested that in the absence of bad faith on the part of the insured, if the facts subject to the non-disclosure or misrepresentation would, if disclosed, warrant a higher premium, then the difference between the actual premium chargeable and the premium received, with interest thereon, should be deducted from the insurance proceeds.

Apart from fraud on the part of the insured, the insurer would then be left with one complete defence, namely, that it would not have accepted the risk if the material facts had been truthfully disclosed. The defence is reasonable in circumstances where the insurer can establish by the industry's practice that such risk is totally unacceptable. To meet these situations, the courts should be prepared to determine whether the facts withheld or misrepresented are serious enough to entirely preclude the acceptance of the risk. It is suggested that so long as the risk is acceptable with a reasonable higher rate of premium, coverage should not be denied and, in the absence of bad faith, claims should be paid.

The cases have also demonstrated that underwriters regard a previous cancellation or refusal of risk as an important circumstance in the acceptance of such risk.538 It is submitted that the insured, not normally equipped with any knowledge of insurance matters, shoulders all the burden of disclosure whereas the insurer, being well versed in such matters only looks to the representations made, with virtually no burden to discharge. It may be noted that in England, an applicant for marine insurance is not required to disclose previous refusals or cancellation of insurance. ${ }^{539}$ It is submitted that where the refusal or rejection is based on legitimate underwriting considerations, it may be regarded as material, but not in cases where it does not affect the quality of the risk. There is no reason why an applicant should not be in a position to obtain a policy after he has been refused once on flimsy or arbitrary grounds.

It is suggested that the law should lay down a rule to the effect that if a refusal or cancellation is not based on legitimate underwriting consideration, the insurer shall not refuse to issue a policy or avoid a claim on this ground. If a refusal is based on such grounds, but the risk is still acceptable, the insurer should be under an obligation to undertake it, although allowed to charge a higher rate of premium or a differential premium as the case may be. In the event of a dispute as to the acceptability of the risk, the evidence of independent expert witnesses, as

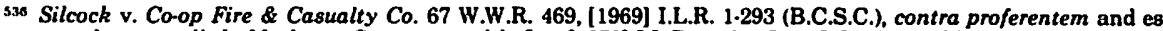
toppel not applied. Marks v. Commonwealth Ins. [1972] I.L.R. 1-484 (Ont. S.C.), insurable interest not found. ${ }^{337}$ Supra, n. 520, 527.

${ }^{334}$ Bowes v. Fire Ins. Co. of Canada (1936) 3 I.L.R. 430 (Ont. S.C.); Ginsberg v. New York Fire Ins. Co. (1937) 4 D.L.R. 585, [1937] O.R. 715 .

339 Glasgow Ass. Corp. v. Symondson (1911) 104 L.T. 254.
} 
suggested earlier, should be admissible. Moreover, an application should only be considered as having been rejected if it has been acted upon by the insurer. ${ }^{540}$

It seems that the courts have applied different tests to fraudulent omissions concerning the cancellation of earlier policies of insurance. They have found that where an applicant knew about the earlier cancellation and its materiality from an insurer's point of view, the omission was fraudulent. ${ }^{541}$ Conversely, such an omission has also been held to be inadvertent. 542

The insured and innocent third parties have also suffered because the courts have not strictly enforced the provision in the provincial Insurance Acts stipulating a fifteen day notice of cancellation of insurance. ${ }^{543} \mathrm{It}$ is suggested that the statutory notice should apply to all terminations of coverage, whether effected unilaterally or by mutual consent, in order to protect the interest of the innocent insured and victims of motor vehicle accidents.

The courts in Canada have found a waiver of information in cases where an applicant fails to answer a question in the application for insurance or draws a dash and the insurers have accepted the application without requiring the insured to supply the omission..$^{544}$ In Alberta ${ }^{545}$ and Manitoba,546 an answer penned with a dash has been treated as a negative answer because the courts in those cases have felt that the insured was telling a lie. It is submitted that the rule should be that where a question is answered with a dash and the non-disclosure results as a default of the agent, the insurer should be deemed to have waived the information. In the absence of clear cut legislation, a shrewd agent in Alberta and Manitoba may get away from the effect of false answers merely by placing a dash, and the insurer, by retaining the premiums, will benefit from the act or omission of its agent. This can be detrimental to the interest of the insuring public.

It is also suggested that insurers be placed under a statutory obligation not to accept an application for insurance unless all the questions in the application have been answered. The enactment should also provide that notwithstanding this provision, if an insurer elects to accept an application with a dash or blank answer, it shall be deemed to have waived the question and no legal defence based on such a non-disclosure will be sustained.

\section{B. Fire Insurance}

In the area of fire insurance, it is suggested that insurers in all the provinces of Canada should be under a statutory obligation to publish prominently in the application for insurance all the material facts required to be communicated, either when applying for the original insurance or upon renewal. The proposer should be warned of the conse-

\footnotetext{
seo Kiernan v. Metropolitan Life Ins. Co. [1925] S.C.R. 600, [1925] 4 D.L.R. 439 (dissenting opinion of Mignault and Rinfret JJ., in the Supreme Court of Canada).

s11 Sherman v. American Ins. Co. [1937] 4 D.L.R. 723 4 I.L.R. 108, (Ont. S.C.).

sez Ginsberg v. New York Fire Ins. Co. [1937] 4 D.L.R. 585, [1937] O.R. 715.

s3 Ellis v. Londony Canada Ins. Co. [1954] 1 D.L.R. 785 (S.C.C.).

st Gabel v. Howick Farmers Mutual Fire Ins. Co. (1917) 38 D.L.R. 139, 40 O.L.R. 158; Sinclair v. Can. Mutual Fire Ins. Co. (1876) 40 U.C. Q.B. 206 (C.A.).

sts Hanson v. Queensland Ins. Co. 57 D.L.R. (2d) 131, 56 W.W.R. 215, [1966] I.L.R. 1-171 (Alta. S.C.).

s46 Hoey v. Merit Insurance Co. [1971] 1.L.R. 1-417 at 1274.
} 
quences of non-disclosure or misrepresentation. Precise periods of time for the disclosure of previous fires should be specified.

The cases have borne out that insurers regard the incendiary dangers to the insured or neighbouring property as a material circumstance which the applicant for insurance must disclose, although there may not be a question in the application to that effect, and the ground of apprehension may later transpire to have been unfounded.547 Can it be expected of an average insurance consumer that he know about any apprehended threats to neighbouring property and their materiality from an insurer's point of view? It is suggested that the law should specifically provide that the non-disclosure of apprehended incendiarism to neighbouring property will not invalidate the policy if it was not known to the applicant when applying for insurance coverage.

It has also been held that any non-disclosure or misrepresentation as to the title of the property is a fact material to the acceptance of the risk and may affect the validity of the policy. Purchasers under agreements of sale, ${ }^{548}$ and those having tax liens but with a right of redemption, ${ }^{549}$ have been held to have an insurable interest. It is suggested that the application form should specifically provide that a person having no insurable interest cannot insure. The proposal form should set forth specific excluded risks, such as those of a nominal owner, a person expecting to acquire insurable interest, a shareholder in the assets of the corporation, or an unsecured creditor in the assets of its debtor. Moreover, it should also be pointed out in the application that the property of any person other than the insured is not protected, unless the interest therein is specifically stated in the application.

An assignee of a fire insurance policy is not protected from the effects of non-disclosure or misrepresentation made by the assignor, unless the insurer expressly accepts the assignee as a new insured. Where, however, the insurer fails to obtain a de novo application from the assignee, the courts may find the insurer cannot raise these defences against the assignee.550 It is suggested that the law should provide that where the insurer accepts the assignee as a new insured and does not require a de novo application, the assignee shall not be bound by the representations made by the assignor. This would save an assignee from the acts or omissions, of the assignor, of which the former may be innocent and have paid insurance premiums over a number of years before being met with any defences available against the assignor.

It has also been held that an applicant for insurance should disclose particulars of mortgages, liens or other encumbrances, foreclosure proceedings, arrears of taxes, and other facts which are material to the risk. ${ }^{551}$ It is suggested that the insurer should frame specific questions on the matters if it wants detailed information.

If a mortgagor fails to honour his duty of disclosure, the mortgagee, in the absence of the standard mortgage clause, cannot escape the conse-

547 Chapman v. Can. Accident Fire Ins. Co. (1929) 37 O.W.N. 320.

sto Marshall v. Wawanesa Mutual Ins. Co. [1924] 2 D.L.R. 419, affirming [1923] 3 W.W.R. 418, 32 B.C.R. 419 , [1923] 3 D.L.R. 696 (C.A.); Tarr v. Westchester Fire Ins. Co. [1952] 2 D.L.R. 281, [1952] O.R. 7, [1952] I.L.R. 355, aff'd. [1953] 2 D.L.R. 655, [1953] O.R. 378, [1953] I.L.R. 518 (C.A.).

ses Barcha v. Atlas Ass. Co. [1924] 2 D.L.R. 836, [1924] 2 W.W.R. 467 (Alta. S.C.).

sso Springfield Fire and Marine Ins. Co. v. Maxim [1946] S.C.R. 604, 13 I.L.R. 108, [1946] 4 D.L.R. 369, affirming [1945] 3 W.W.R. 705, 13 I.L.R. 7, [1946] 1 D.L.R. 357, which rev'd. [1945] 4 D.L.R. 115. [1945] 3 W.W.R. 209, 12 I.L.R. 319.

ssi Chenier v. Madill [1974] I.L.R. 1.585 at 1931 . 
quences of non-disclosure of, or a misrepresentation made by, the former. Thus the interest of the mortgagee is susceptible to being defeated by any fraudulent omission, misrepresentation or breach of any statutory condition. Section 222 of the Alberta Insurance Act552 does not sufficiently protect the interest of the mortgagee as it merely provides for statutory notice to loss payees before cancellation of the policy. It is submitted that section 222 should be amended to provide that the loss payee who has given value for his interest in the property shall not be prejudiced by any act, neglect, omission or misrepresentation attributable to the insured.

\section{Life Insurance}

In the area of life insurance, answers to questions on medical examinations may be written out by the company's doctor and the application signed by the proposed assured without reading it. Where any omission or misrepresentation is attributable to the company's medical examiner, the courts have found the insurer liable, as the medical officer is the company's representative. ${ }^{553}$ It is suggested that this should be embodied in the Insurance Act. This same rule should apply equally to cases where non-disclosure or misrepresentation results through the fault of the insurance agent. The problems of the insuring public might thus be alleviated to a greater extent.

It has been held that an applicant for life insurance should disclose previous physical examinations, x-rays, electrocardiograms or normal check-ups which did not reveal any disease or symptoms of disease. ${ }^{554}$ In the absence of searching questions emphasizing their importance, the average consumer should not be required to disclose such facts. Moreover, a consumer can hardly be expected to know that there could be a difference of opinion arnong medical experts as to the result of such examinations, and that he must disclose them notwithstanding the assurance of a number of doctors that he does not suffer from any disease. $^{565}$ It is suggested that if the insurer fails to frame appropriate questions, the law should provide that the insurer shall not be allowed to base a defence on grounds of non-disclosure or misrepresentation.

The cases have shown that where the proposed assured is not subjected to a medical examination by the insurer, the courts have prevented the insurer from escaping liability if the non-disclosure or misrepresentation was inadvertent. 556 In industrial assurance, a condition in lieu of medical examination is attached, stipulating that the policy shall be void if the assured suffers from certain specified diseases. ${ }^{557}$ It is suggested that if no medical examination is required by the insurer, either for life insurance or industrial assurance, the insurer, in the absence of bad faith on the part of the assured, should be under an obligation to pay the claim.

The courts have accepted the plea of insurers that non-disclosure or misrepresentation of certain facts is material even in circumstances

\footnotetext{
ss2 Supra, n. 51 .

sss Pearce v. National Life Ass. Co. (1908) 12 O.W.R. 359 (Ont. C.A.); Lacroix v. L'Industrielle Compagnie d'Assurance Sur La Vie [1970] I.L.R. 1-314 at 875 .

ss4 Supra, n. 527.

s5s Id.

sse Turner v. B.C. Mutual Benefit Association [1927] 4 D.L.R. 541, [1927] 3 W.W.R. 341, 39 B.C.R. 209 (B.C.C.A.).

s.7 Moore v. Metropolitan Life Ins. Co. (1923) 54 O.L.R. 474 (Ont. CA.).
} 
where the death has resulted from unrelated natural ${ }^{558}$ or accidental causes. ${ }^{559}$ This plea seems weak because the cause of the death is not of the disease complained. The insurer will not be prejudiced if he is allowed to charge a differential premium, as suggested earlier. The insurer should not, therefore, be allowed to negative the beneficiary's claim in such cases.

\section{Automobile Insurance}

In the area of automobile insurance, the cases have shown that where an applicant for coverage has knowingly failed to disclose 560 or has knowingly misrepresented previous accidents, ${ }^{561}$ his right of recovery under the policy is forfeited. The insurers however, have not been required to established that they would not have accepted the risk if the previous accidents had been truthfully disclosed. The involvement of the insured in a few accidents does not necessarily mean that the risk is unacceptable. It is suggested that if automobile insurance be compulsory, all reasonable risks should be covered. Moreover, in the absence of bad faith on the part of the insured, the defence of non-disclosure or misrepresentation of previous accidents should be abolished by amending legislation and replaced by a system of differential premiums depending upon the nature of each risk insured. Where the insured discloses accidents, the premium should be increased for each accident. An insured having no record of claims should be given a discount upon renewal.

The courts have allowed the insurers to deny liability to the insured in cases where the former had received an abstract of the applicant's driving record but had not repudiated the contract. ${ }^{562}$ It is suggested that insurers should apply to the Minister of Transport for an abstract of the driving record of the insured, and in cases where such an abstract is issued, they should be estopped from pleading non-disclosure or misrepresentation of previous accidents which appear in the abstract.

The cases have also demonstrated that insurers can avoid liability if they can establish a suspension or cancellation of a driving license. ${ }^{.63}$ It is suggested that where such facts are not disclosed, or are misrepresented to the insurer, indemnity should not be denied, except in cases of bad faith on the insured's part. Rather, a differential premium should be charged if the proper disclosure of such facts would have increased the risk. This result is desirable both from the point of view of the insured himself, and from the viewpoint of third persons who suffer personal injuries or property damage as a result of the insured's operation of a motor vehicle. Present legislation protects such innocent third parties to a limited extent only.

The insured is under a strict duty to disclose at each renewal any suspension or cancellation of a license which occurred during the currency of the preceding policy or renewal, although the insurer may not require a de novo application. This is required despite the fact that the attention of the insured at the time of the original application is not drawn to the fact that he has such a duty upon renewal. ${ }^{564}$

\footnotetext{
sse Supra, n. 554.

sso Supra, n. 520.

s6o Bertrand v. Compagnie Francaise du Phenix [1946] Que. K.B. 81, (1946) 13 I.L.R. 33.

s61 Lannigan v. U.S. Fire Ins. Co. [1956] IL.R. 1-225, [1956] O.W.N. 469.

saz Silcock v. Co-op Fire \& Casualty Co. (1969) 67 W.W.R. 469, [1969] I.L.R. 1-283 (B.C.S.C.).

ses Walter v. Traders Gen. Ins. Co. [1965] I.L.R. 1-136 at 680 (N.S.S.C.).

sot Turgeon v. Atlas Ass. Co. [1969] S.C.R. 286, [1969] I.L.R. 1-259 (sub nom. Turgeon v. Fortin).
} 
It is suggested that the application form for automobile insurance approved by the Superintendents of Insurance should contain a warning in vivid red ink that the insured is under an obligation to disclose the required information on further renewals. In the absence of such a provision, and upon the failure of the insurer to require a fresh application on renewal, no legal defence based on the non-disclosure of such information should be entertained by the courts.

The cases illustrate that innocent third party motor vehicle collision victims are not protected in cases where the true owner of the vehicle, for one reason or another, does not arrange insurance in his own name, but enters into a sham transaction with another, who, for the convenience of the true owner, becomes a supposed owner. ${ }^{565}$ An application for automobile insurance is then made by the alleged owner who falsely represents himself to be the true owner. In the case of an accident, the victims cannot be indemnified because the supposed owner has neither true ownership nor control over the use of the vehicle and no insurable interest therein. The policy does not cover the true owner because he is not a named insured, and he cannot be said to be driving the vehicle with the permission of the supposed owner, who is the named insured.

The courts have failed to uniformly enforce the provision of section $306(5)$ of the Alberta Insurance Act, ${ }^{566}$ to the benefit of the victims. ${ }^{567}$ The insurer under this section can be prevented from claiming that a motor vehicle liability policy issued by it is not a motor vehicle liability policy.

It is suggested that in order to protect third party victims, section $306(5)$ of the Alberta Insurance Act, ${ }^{568}$ and equivalent legislation in other provinces, ${ }^{569}$ should explicitly provide that an insurer is under an obligation to pay damages to the victims whether the policy issued by it to the named insured is an owner's policy or not. The insurer may, however, be entitled to reimbursement from the insured, i.e., the supposed owner because he has falsely represented himself as the true owner and thus induced the insurer to enter the contract. In such an eventuality, the supposed owner will be rightly penalized for making a false representation as to ownership.

\section{Critique of Statutory Provisions}

The provisions in the provincial Insurance Acts do not set out proper standards of disclosure. Drafting as between different parts of the Insurance Acts is not uniform and even in particular parts of the Acts, there are different standards prescribed. It seems that the draftsmen are not clear in their minds as to the present common law position and as to the results to be achieved.

A. Fire Insurance.

In fire insurance, statutory condition 1 enacted under section 223 of the Alberta Insurance Act ${ }^{70}$ provides for avoidance of a contract in cases

sss Comer v. Bussell [1940] S.C.R. 506, [1940] 3 D.L.R. 417, 7 I.L.R. 247, affirming [1940 1 D.L.R. 97, 7 I.L.R. 44, which rev'd. 7 I.L.R. 49 (sub nom. Johnson and Kwaluk v. Bussell); Minister of Transport v. London \& Midland Gen. Ins. Co., (1971) 19 D.L.R. (3d) 643 (Ont. C.A.).

ses Supra, n. 51.

367 Wolfe v. Oliver (1973) 34 D.L.R. (3d) 669 [Section 306(5) applied]; Comer v. Bussell and Minister of Transport v. London \& Midland Gen. Ins. Co., supra, n. 56 [Section not applied].

368 Supra, n. 51.

se9 R.S.B.C. 1960 , c. 197, 8. 242; R.S.M. 1970, c. I-40, 8. 258; R.S.O. 1970, c. 224, 8. 255.

370 Supra, n. 51. 
of a fraudulent omission or non-disclosure of material facts; but only as to the property in relation to which non-disclosure or misrepresentation is made. This statutory condition warrants several comments.

It is very difficult for an insurer to prove fraud on the part of the insured, and the latter may overcome the insurer's defence of nondisclosure by proving that he inadvertently forgot to disclose the material facts or in good faith believed them to be immaterial.571 Moreover, an insured may benefit by his own fraud because it does not affect the entire contract and the insured can still recover in respect of the property not affected. ${ }^{572}$ Conversely, an innocent misrepresentation avoids the policy as to property in relation to which the misrepresentation is made. It is submitted that the statutory condition should act in fairness to both the insured and the insurer.

It follows that in order to avoid a fire policy, an omission must be fraudulent, but a misrepresentation need only be innocent; although the insurer is prejudiced more on account of the innocent non-disclosure of two fires than by an innocent misrepresentation of one fire. This has resulted in a rather puzzling disparity between the position of two insured, and requires the courts to make fine distinctions between nondisclosure and misrepresentation innocently made. ${ }^{573}$ This anomaly is not readily justified.

The statutory condition has the effect of taking away the common law defence of innocent non-disclosure. Surprisingly, the legislatures have not deemed it desirable to extend this requirement for a fraudulent intention to misrepresentation.

The statutory condition is silent as to the effect of fraudulent omission or misrepresentation of material facts which do not relate to the property, but which may have bearing on the acceptance of the risk, i.e., moral hazard. ${ }^{574}$

The wording of the statutory condition is very wide in that it does not make it specifically clear that the duty to disclose material facts arises only in response to direct questions asked in the application.

It is surprising that a misrepresentation in order to avoid a fire policy need only be innocent, but that if the property is innocently over-valued, by virtue of section 219 of the Alberta Insurance Act, ${ }^{575}$ the policy will not be vitiated. The insured, in the event of total loss, can recover the loss and the premium representing the difference between the sum insured and the appraised value of the property for purposes of the loss. It is submitted that the provisions of section 219 are little known and infrequently applied.

It may be noted that in the United States, only seven states have provided for fraudulent intent as an essential element of non-disclosure. In the majority of the jurisdictions, insurers may repudiate liability even in cases where the insured honestly and in good faith believed that the facts not disclosed were immaterial, provided that the insurer can establish their materiality from its point of view. ${ }^{576}$

\footnotetext{
37 Supra, n. 542.

572 Harten v. Grenville Patron Mutual Fire Ins. Co. [1938] 2 D.L.R. 772, [1938] O.R. 500, 5 I.L.R. 87.

${ }^{5: 3}$ Taylor v. London Ass. Corp. [1935] S.C.R. 422, [1935] 3 D.L.R. 129.

57. Heighington, Firc Insurance-Fraud and Misrepresentation-Statutory Condition 1-Summary of recent cases (1956) 34 Can. Bar Rev. 93 at 100.

573 Supra, n. 51.

s76 Salzman, Misrepresentation and Concealment in Insurance, (1970-71) 8 Am. Bus. LJ. 119 at 130.
} 
It is suggested that the defence of fraudulent omission should be abolished, and that the insurer should be allowed to avoid a fire policy if an insured, in bad faith, fails to disclose or misrepresents material facts. However, where an insured can establish that the statement was true to the best of his knowledge and belief, no defence should be allowed on the basis of such misstatement. Materiality should be judged from a reasonable insured's point of view, and the burden of proving bad faith should be placed on the insurer. The entire contract should be void for non-disclosure or misrepresentation made in bad faith, but the statutory condition should clearly provide that the duty to make full disclosure arises only in connection with specific questions asked. Moreover, the condition should spell out the effect of non-disclosure or misrepresentation relating to moral hazards.

Section 220 of the Alberta Insurance Act577 is a unique piece of legislation, as other provinces do not seem to have a similar provision. The section points out what facts the insurer must require the proposed insured to disclose in the application for insurance. It requires the "particulars of all previous fire claims made by the applicant" and whether any insurer has cancelled any fire policy or refused fire insurance to the applicant. The wording of the section will pose a problem where an insurer in his application for a policy has prescribed a precise period for the disclosure of fires and the applicant has disclosed accordingly. The insurer in such an eventuality may invoke the section to its benefit as the statute is deemed to override the requirements of the application form. The section in requiring disclosure of previous fire claims and cancellation of previous insurance over an indefinite period of time is too wide. The section, however, does not require the disclosure of incendiary dangers.

It is suggested that the section should prescribe a period for the disclosure of previous fire claims, and that it should also require the disclosure of incendiary dangers to the insured property.

\section{B. Life Insurance}

In life insurance, under section 240 of the Alberta Insurance Act, 578 and its corresponding legislation in other provinces, ${ }^{579}$ a contract may be voidable for innnocent non-disclosure or misrepresentation of material facts within the knowledge of the applicant or the life insured. The insured may thus be unable to recover the premiums paid. The predecessor to this section, enacted in 1926,580 was more favourable to the insured as it required conscious failure to disclose. The present section may also impose an unduly severe duty of disclosure of material facts about which no question is asked. In the absence of fraud, this would be too much to demand from the insured who is not equipped to decide matters of materiality.

It is suggested that the defence of innocent non-disclosure or misrepresentation be abolished, and the insurer should be allowed to avoid a life insurance policy, if the insured in bad faith fails to disclose or misrepresents material facts. Moreover, this section should make it clear that the duty of disclosure arises in response to questions asked in the application.

577 Supra, n. 51.

$\operatorname{sis} I d$.

s79 Insurance Acts: R.S.B.C. 1960, c. 197, s. 123; R.S.M. 1970, c. 1-40, 8. 160; R.S.O. 1970, c. 224 , s. 157.

sko Insurance Act, S.A. 1926, c. 31, s. 202(2). 
A life insurance contract under section 241 of the Alberta Insurance Act ${ }^{581}$ becomes uncontestable after a period of two years. if the insured, who is guilty of non-disclosure or misrepresentation, dies one day short of two years, the claim of the beneficiary is prejudiced, but if he dies at any time after the said period, the beneficiary's interest is fully protected unless the insurer can prove fraud on the part of the insured.

Where the facts withheld or misrepresented would have resulted in a higher premium if properly disclosed, and the insured dies within two years, it is suggested that the differential premium be charged for a full two years and that the contract be made uncontestable vis-a-vis a claim by the beneficiary. This would bring to an end any inequality between the position of innocent beneficiary, whether the policy has been in effect for less or more than two years, save in the event of fraud provable against any party under a duty of disclosure.

\section{Automobile insurance}

In automobile insurance, under section 287 of the Alberta Insurance Act, ${ }^{582}$ a claim by the insured is forfeited if he knowingly misrepresents or fails to disclose in the application any fact required to be stated therein. The word "knowingly" rules out any possibility of avoidance of contract for innocent non-disclosure or misrepresentation and is to be preferred, as the insurer must establish non-disclosure or misrepresentation and the knowledge of material facts on the part of the insured.

The section gives an impression that only a claim by the insured is forfeited and that a person other than the insured, e.g., a third party accident victim, is protected in the event of misrepresentation or failure to disclose material facts by the insured. But, as indicated earlier, protection of the victims is limited in the view of section 306(5) of the Alberta Insurance Act. ${ }^{583}$

Section 287, read in conjunction with subsection 194(9), gives an impression that a misrepresentation or misdescription made knowingly will forfeit a claim whether it be material or not, unless it can be successfully argued that a "fact required to be stated" in the application is always material, although a contrary judicial opinion has been expressed. 584

It is suggested that only a non-disclosure or misrepresentation of material facts made in bad faith by the insured, judging the materiality from a reasonable insured's point of view, should invalidate the claim of the insured. Moreover, where the insurer fails to obtain a de novo application, the contract should be deemed to be renewed on the basis of information contained in the original application. The insurer should be precluded from using defences which rely upon changes in material circumstances about which it has not seen fit to require. The insured should, however, be under a duty to give notice of changes material to the risk occurring during the currency of the policy.

The disparity in the standards of disclosure in different branches of insurance may be summarized thus:

An omission must be "fraudulent" in fire insurance; made "knowingly" in automobile insurance; but may be innocent in life insurance. Conversely, misrepresentation must be made "knowingly" in automobile insurance; but may be innocent in fire and life insurance. In all cir-

\footnotetext{
s81 Supra, n. 51.

582 Id.

583 Id.
} 
cumstances, the insured will be unable to claim indemnity, although results will perhaps differ as to the return of premiums. This occurs because a fire insurance contract is "void"; a life insurance contract "voidable" and a claim by the insured under a contract of automobile insurance is "forfeited", if the duty of disclosure as laid down in the respective sections or statutory condition is breached.

Moreover, statutory condition $1^{585}$ relating to fire insurance and section 240 of the Alberta Insurance Act 586 concerning life insurance, provide that omissions or misrepresentations must be of material facts; whereas section 287 of the Alberta Insurance Act, ${ }^{587}$ dealing with automobile insurance, does not talk about materiality.

Statutory condition 1 and section 240, due to unclear drafting, convey an impression that an insured in fire and life insurance may be under a strict duty to disclose material facts, although a particular question is not asked. In automobile insurance, the language of section 287 is clear and the insured is under no obligation to make disclosures dehors the application.

The duty of disclosure in fire insurance is to be found in a statutory condition,,$^{588}$ whereas the same provision in life $e^{589}$ and automobile $e^{590}$ insurance has been enacted in the substantive portions of the provincial Insurance Acts.

Section 286(5) of the Alberta Insurance Act ${ }^{591}$ requires the insurer to publish on every application form and in the policy for automobile insurance, in a conspicuous manner, the provisions of section 287 dealing with the duty of disclosure. Section $223(1)$ requires that statutory condition 1 dealing with the duty of disclosure in fire insurance be printed on every policy. There is no such publication requirement in respect of life insurance contracts. Section 286(5) is, therefore, to be preferred.

It must be concluded that the legislation in this area is in a confused state. It must also be concluded that the consumer of insurance has not received sufficient legislative protection in the form of fair and coherent rules regulating the standards of disclosure in insurance contracts.

It is suggested that a uniform standard be prescribed for nondisclosure and misrepresentation in fire, life and automobile insurance, Where disclosure would have warranted a higher premium, the insured, in the absence of bad faith on his part, should be allowed a claim, subject to the charge of a differential premium. Where the risk would not have been acceptable at all, the claim may be avoided. The duty of disclosure should be regulated by substantive sections in the insurance statutes and they should be published on every application and policy form in all the branches of insurance. Insurance companies should be penalized for failing to do so.

It is suggested that the Association of Superintendents of Insurance direct their efforts toward clearing up the present lack of uniformity and

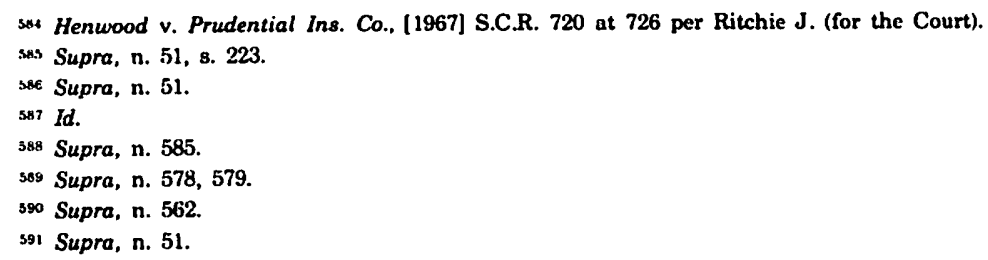


cohesiveness in each of the provincial Insurance Acts and toward further improvements in the law in the important area of the duty of disclosure. It is hoped that the present study and the reforms proposed may lead to further review and positive action.

\section{SUMMARY OF RECOMMENDATIONS}

The following proposals for reform arise out of the foregoing study: 1. An insurance agent should be deemed to be the agent of the insurer for all purposes of soliciting applications and policies, whether he acts innocently or fraudulently, or whether he acts in the insurer's interest or not. Where the applicant for insurance is guilty of fraudulent nondisclosure or misrepresentation his claim should be barred by reason of his fraud, and not by reason of any rule governing insurance agents.

2. A uniform standard should be prescribed for non-disclosure or misrepresentation in fire, life and automobile insurance.

Where material facts have been misrepresented or have not been disclosed with no bad faith or fraud on the part of the insured, a claim should be allowed, subject to a deduction of the amount by which the premiums would have been increased over the term of the coverage had all material facts been properly disclosed. The extent of this increase in the premium could be determined by an appropriate tribunal with authority to take into account the opinion of insurance experts as well as representatives of the insuring public.

Only in the event that the insurer could prove bad faith on the part of an insured could a claim by that insured be avoided.

3. In the event that the uniform standard for disclosure proposed in the second recommendation is not implemented, the common law test of materiality should be changed from the test of the "reasonable insurer" to that of the "reasonable insured".

4. The defence of innocent non-disclosure or misrepresentation should be available for purposes only of increasing the premium as suggested in the second recommendation, but should no longer be available for purposes of avoiding coverage.

5. If the second recommendation is not carried out, then in the area of fire insurance, the defence of innocent misrepresentation should be abolished and the policy should only be subject to avoidance for misrepresentation or non-disclosure made in bad faith. This would eliminate the present anomaly under section 223(1) of the Alberta Insurance Act, which allows defences based on fraudulent non-disclosure or innocent misrepresentation. The entire contract should be voidable only for nondisclosure or misrepresentation made in bad faith.

6. Application forms and policies drafted by insurers should be the subject of thorough screening and approval by a tribunal consisting of consumer representatives and insurance experts to ensure that they conform to proper legal standards. Such a tribunal has already been suggested in the second recommendation for purposes of determining differential premiums.

As regards disclosure, it is suggested that such a tribunal enforce the following minimum standards:

(a) Insurers should be required to frame specific and appropriate questions in the application form. 
(b) Insurers should be obligated to print, in a conspicuous manner, the sections dealing with the duty of disclosure and the statutory rights and duties of the insured, on every application and policy form in all branches of insurance.

(c) Insurers should be under a duty to warn the insured that he is under an obligation to disclose certain information on further renewals.

(d) Insurers should be required to vividly warn the insured, in the application for insurance, of the consequences of non-disclosure or misrepresentation.

7. A publicly funded advisory or educational body should be set up to explain essential features of insurance to consumers. If thought appropriate, this function could be assigned to the tribunal already referred to in recommendations two and six.

8. Insurers should no longer be allowed to deny coverage of a risk if that risk is acceptable at a suitable rate of premium. This is particularly desirable in areas such as automobile insurance where the consumer is constrained by law to obtain coverage. An insured having no record of claims should be given a discount on renewals. Insurers should no longer be able to refuse coverage or avoid claims for refusal or cancellation of insurance if such refusal or cancellation was not based on legitimate underwriting considerations.

9. The statutory period should apply to all termination of coverage whether effected unilaterally or by mutual consent. This would give a minimum continued coverage even where an insured voluntarily surrenders the policy. Such a grace period would allow the insured to obtain new coverage without running the risk of a loss in the interim period. 10. If the insurer accepts an application with a dash or blank answer without insisting that the applicant supply the omission, it should be deemed to have waived the question.

11. In the area of fire insurance, the Alberta Insurance Act should specify the precise period of time in respect of which an insured must disclose any fires he has suffered. This would make the Act consistent with the usual terms of the application form.

12. Where the insurer accepts the assignee of the property as a new insured and does not require a de novo application, the latter should not be bound by the misrepresentations or non-disclosures attributable to the assignor.

13. In the area of fire insurance, whether or not a policy includes a standard mortgage clause, the provincial Insurance Acts should provide that a loss payee, who has given value for his interest in the property, should not be prejudiced by any act, neglect, omission or misrepresentation attributable to the insured.

14. In the area of life and industrial assurance, where no medical examination is carried out, and the insured establishes that the disclosure in the proposal form was true to the best of his knowledge and belief, non-disclosure of a latent disease should not, in the absence of bad faith on the part of the insured, allow the insurer to avoid the claim.

15. In the area of automobile insurance, if the insurer relies upon the driving record of the insured, which appears in the abstract available to it, it should be estopped from pleading non-disclosure or misrepresentation of those accidents.

16. Insurers should be under a statutory duty to pay damages to the victims of automobile accidents whether the policy issued to the named insured is an owner's policy or not. For the protection of the interest of 
the victims, the law should imply consent of the insured in cases of use of the vehicle by a person with whom the insured has colluded in obtaining coverage.

17. The duty of disclosure in fire, life and automobile insurance should be regulated in a uniform manner. The present disparities in statutory conditions and substantive sections should be removed. Moreover, all the sections should expressly provide that there is a duty to disclose only those facts which are material to the risk.

18. The Association of Superintendents of Insurance should direct its efforts toward remedying the lack of uniformity and cohesiveness in each of the provincial Insurance Acts and toward further improvement of the law of the duty of disclosure. 